Andrews University

Digital Commons @ Andrews University

1983

\title{
A Study of Productivity in Ministry as Related to South America Division
}

Itamar Sabino De Paiva

Andrews University

Follow this and additional works at: https://digitalcommons.andrews.edu/dmin

Part of the Practical Theology Commons

\section{Recommended Citation}

De Paiva, Itamar Sabino, "A Study of Productivity in Ministry as Related to South America Division" (1983). Professional Dissertations DMin. 708.

https://dx.doi.org/10.32597/dmin/708

https://digitalcommons.andrews.edu/dmin/708

This Project Report is brought to you for free and open access by the Graduate Research at Digital Commons @ Andrews University. It has been accepted for inclusion in Professional Dissertations DMin by an authorized administrator of Digital Commons @ Andrews University. For more information, please contact repository@andrews.edu. 


\section{ABSTRACT}

\section{A STUDY OF PRODUCTIVITY IN MINISTRY AS \\ RELATED TO SOUTH AMERICAN DIVISION}

by

Itamar Sabino de Paiva

Chairman: Werner Vyhmeister 


\title{
ABSTRACT OF GRADUATE STUDENT RESEARCH \\ Project. Report
}

Andrews University

Seventh-day Adventist. Theological Seminary

\begin{abstract}
Title: A STUDY OF PRODUCTIVITY IN MINISTRY AS RELATED TO THE SOUTH AMERICAN DIVISION

Name of researcher: Itamar Sabino De Paiva

Name and degree of faculty adviser: Werner Vyhmeister. Ph.D.

Date completed: August 1983
\end{abstract}

This study is concerned with the attributes of the ministry as depicted in the Bible and the writings of Ellen G. White as well as with an evaluation of ministerial productivity in selected unions of the South American Division (SAD). Those who have dealt with the problem of evaluation have focused mainly on the numerical achievements or quantitative aspects of ministerial productivity. Although evaluation of qualitative characteristics may be more difficult than that of quantitative characteristics, failure to include both aspects of the minister's work may well result in an inaccurate and unbalanced profile of his accomplishments. 
Consequently, there is a need to clarify the understanding of ministerial productivity between pastors in the field and administrators.

The first part of this study attempts to arrive at an understanding of the nature and mission of the church by examining images of the church and of the minister and/or ministry in the Bible and the writings of Ellen G. White. Indirectly, then, one may infer criteria for measuring effectiveness of the minister from these qualifications. From Paul's letters to the Galatians, Timothy, and Titus a list of nearly thirty basic qualifications for a mature and productive ministry may be derived. It would appear that high productivity in the ministry calls not only for ability to edify spiritually but also competency in utilizing the talents of church members in every aspect of the overall mission of the church. Thus the nature and mission of the church provide the framework within which productivity may be viewed.

The second section of the paper attempts to explore current understandings of ministerial productivity in the SAD. While administrators and the pastoral ministry both recognize how essential time is for development of the spiritual dimension of the minister and the implications for leading congregations to spiritual vitality, it would appear that the heavy demands and emphasis on activityrelated dimensions of the minister's responsibilities markedly reduce the amount of time allotted for study. However, provision for increased study time, an organized initial internship program, and imaginative continuing education courses may well enhance the qualitative aspects of the ministry. In time, ministerial productivity 
3

may be so enhanced that the contribution of the qualitative aspects may become more apparent and qualitative evaluations tools may be more easily developed. This could provide a more balanced and accurate profile of the productivity of the ministry in the South American Division. 
Andrews University

Seventh-day Adventist Theological Seminary

\author{
A.STUDY OF PRODUCTIVITY IN MINISTRY AS \\ RELATED TO SOUTH AMERICAN DIVISION
}

\begin{abstract}
A Project
Presented in Partial Fulfillment

of the Requirements for the Degree

Doctor of Ministry
\end{abstract}

by

Itamar Sabino de Paiva

August 1983

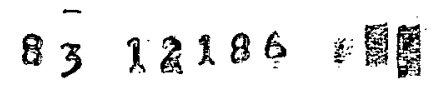

,$\quad 007$ 
A STUDY OF PRODUCTIVITY IN MINISTRY AS RELATED TO SOUTH AMERICAN DIVISION

A project report presented in partial fulfillment of the requirements for the degree Doctor of Ministry

by

Itamar Sabina de Paiva

APPROVAL BY THE COMMITTEE:
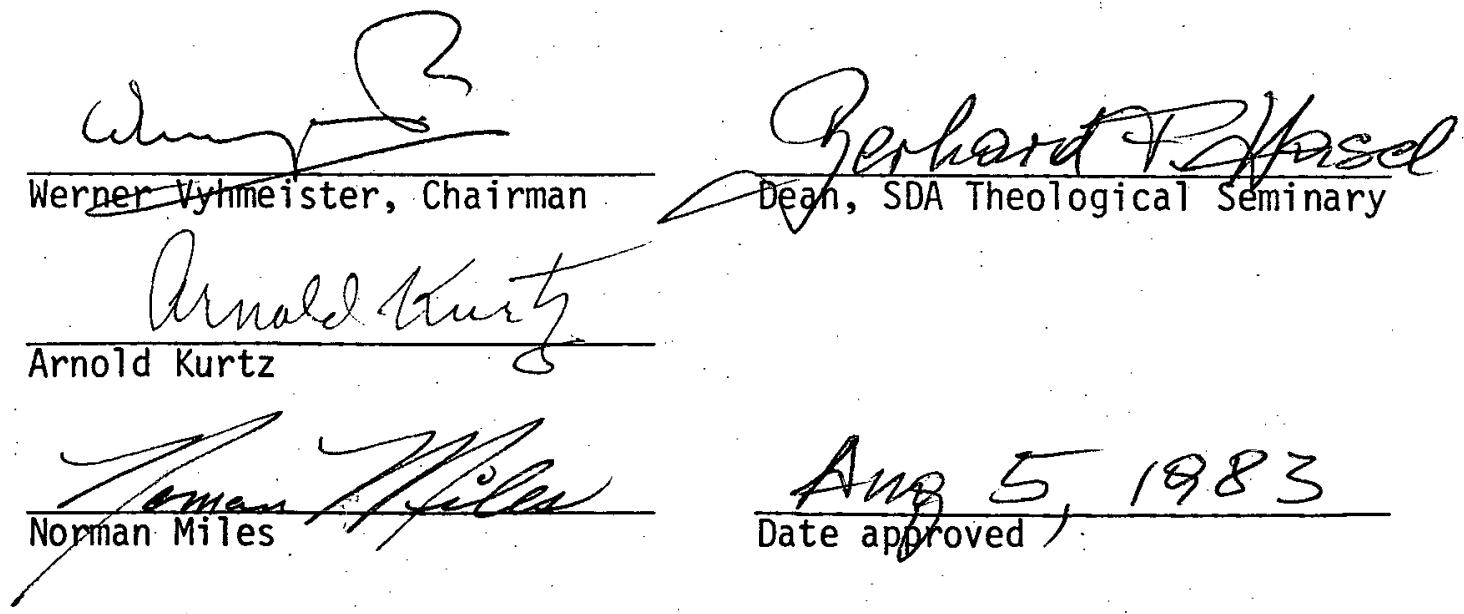

An g 5,1983 Date approved 



\section{IN LOVING DEDICATION}

In memory of Silvia, my Christian mother, who before I was born dedicated me to the ministry, and who encouraged me until her dream was realized.

To Ruth, my lovely wife, who for almost twenty-four years has supported and enhanced my ministry.

To our dear sons, Ruimar, Elimar, Emerson, and Herman, who are preparing to serve in the Lord's cause. 


\section{TABLE OF CONTENTS}

LIST OF TABLES ................. vii

ACKNOWLEDGMENTS .................... ix

PART I. IMAGES OF THE CHURCH AS RELATED TO

EFFECTIVENESS IN MINISTRY

Chapter

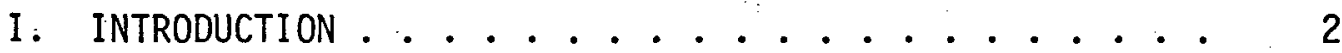

Statement of the Problem ........... 2

Justification for the Study . . . . . . . . 3

Definition of Terms ........... . . 4

Overview.............. 5

II. TOWARD A THEOLOGICAL UNDERSTANDING OF

EFFECTIVENESS IN MINISTRY ............ . . 6

The Nature of the Church . . . . . . . . 6

Biblical Images .............. 7

The Bride of Christ . . . . . . . . 7

The People of God ............ . . 8

The Temple of God . . . . . . . . . . 10

The Body of Christ . . . . . . . . . . 11

Images in the Writings of Ellen G. White.... 13

The Garden of God . . . . . . . . . 13

The Army of Prince Emmanuel . . . . . . . 13

The Mission of the Church ......... . . 14

The Vital Mission of the Church . . . . . . . 15

The Organic Mission of the Church . . . . . . 16

The Expansional Mission of the Church . . . . . 18

Summary .............. . 19

III. BIBLICAL AND ELLEN G. WHITE CRITERIA OF

The Divine Call ............... 21

The Holy Spirit (Baptism) . . . . . . . . 26

Personal Qualifications .......... 27

Characterizations of Ministry ........ 28

The Ministry as a Covenant ......... 28

The Ministry as Commitment . . . . . . . . 29

The Ministry as a Commission...... 29 
Chapter

III. (Continued)

The Ministry as a Consecration ....... . 30

The Ministry as a Challenge ........ 30

The Ministry as a Continuation of Christ's Ministry. .......... 31

The Ministry Involves a Summons to Reformation ........... 32 Natural Talents ............ . . 33 Acquired Qualifications .......... 35 Summary ................ 37

IV. MINISTERIAL ROLES AS RELATED TO PRODUCTIVITY . . . . 38

Ministerial Roles from OT Images . . . . . . . 38

The Priesthood............. . 39

The Prophetic Role .............. . 40

The Prophet as a Man of God ......... 41

The Prophet as a Watchman ........ 42

The Prophet as a Servant of the Lord . . . . . 42

Ministerial Roles from NT Images . . . . . . . 43

The Minister as a Messenger ......... 43

The Minister as a "Fisherman" . . . . . . . . . 44

The Minister as Shepherd ........... 44

The Minister as a Fellow-Laborer ........ 45

The Minister as a Steward ........... 46

The Minister as an Ambassador ........ . 47

The Minister as a Husbandman . . . . . . . . . 48

The Minister as a Model . . . . . . . . 49

Summary ............. 50

PART II. PERSPECTIVES ON MINISTERIAL

EFFECTIVENESS IN THE SOUTH-AMERICAN

DIVISION OF SEVENTH-DAY ADVENTISTS

V. SOME CURRENT UNDERSTANDINGS OF MINISTERIAL

EFFECTIVENESS IN THE SOUTH-AMERICAN DIVISION .....

Survey of Mission, Conference, and

Union Presidents............ . . 53

Open-ended Questions ............ 54

Question 1................. 54

Question 2................. 56

Question $3 \ldots \ldots . . . . . . . .657$

Question $4 \ldots . . . . . . . . .59$

Question 5.................. 60

Question $6 \ldots \ldots$................. 61

Question $7 \ldots \ldots . . . . . . .664$

The Objective Questionnaire ........ 66

Personal Factors .............. . . 67

Leadership and Administrative Factors . . . . 70

Pastoral Factors ........... 74 
Chapter

V. (Continued)

Preacher/Evangel ist Factors . . . . . . . 76

Statistical Measurements . . . . . . . . 78

Subjective Evaluation of Ministerial

Effectiveness ............ 80

Ministerial Evaluation Questionnaires ..... 81

Evaluation Instrument of Union C . . . . . . 81

Ministerial Evaluations of Union D...... . 83

Evaluation Instrument of Union E . . . . . . 84

Interview with Former SAD Leaders at AU . . . . 86

Case Studies................ 88

Case Study: Pastor "A" . . . . . . . . 88

Case Study: Pastor "B" ........... 91

Comparison of the Two Case Studies . . . . . . 93

Similarities............. 93

Contrasts ............... 93

Summary .. . . . . . . . . . . 95

Conclusions . . . . . . . . . . . . . 97

Recommendations ............. 99

APPENDICES ......................... 103

A. Questionnaire and Covering Letter........ 104

B. Evaluation Instrument Union C ......... 118

C. Ministerial Evaluation of Union D ........ 140

D. Evaluation Instrument Union E......... 152

BIBLIOGRAPHY ........................... 172

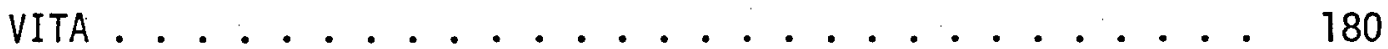




\section{LIST OF TABLES}

1. Responses of the Administrators to the Question

Pertaining to the Length of the Pastoral Term . . . 60

2. Evaluation of the Criteria that Govern the

Concept of Ministerial Productivity in

Adventist Ministerial Functions According

to Selected SAD Union, Conference, and

Mission Administrators: Personal Factors . . . ... .

3. Evaluation of the Criteria that Govern the Concept

of Ministerial Productivity in Adventist

Ministerial Functions According to Selected

SAD Union, Conference, and Mission

Administrators: Leadership and Administrative

Factors ................ 71

4. Evaluation of the Criteria that Govern the Concept

of Ministerial Productivity in Adventist

Ministerial Functions According to Selected

SAD Union, Conference, and Mission

Administrators: Pastoral Factors . . . . . . 75

5. Evaluation of the Criteria that Govern the Concept

of Ministerial Productivity in Adventist Ministerial

Functions According to Selected SAD Union, Conference, and Mission Administrators:

Preacher/Evangelist Factors . . . . . . . . .

6. Evaluation of the Criteria that Govern the Concept

of Ministerial Productivity in Adventist

Ministerial Functions According to Selected

SAD Union, Conference, and Mission

Administrators: Statistical Measurements ...... 
NOTE

This Doctor of Ministry Project report falls under the category described in the Seminary Bulletin as Project II, in fulfillment of requirements for an alternate curriculum plan under which the candidate prepares two related papers--a theological position paper addressing some issue or problem in the church theologically, and a professional paper addressing this issue or problem from the standpoint of ministerial practice. 


\section{ACKNOWLEDGMENTS}

While the writer is indebted to many individuals who have kindly contributed to the completion of this project in one way or another, special recognition should be given to the following:

Dr. Arnold Kurtz, director of the course, for his valuable counsel, patience, and understanding throughout this project.

Dr. Normal Miles, member of the committee, for his helpful advice and the valuable courses in church management.

Drs. Werner and Nancy Vyhmeister, whose friendship, support, and encouragement even before our arrival at Andrews University, and which has continued throughout my graduate studies to the completion of the final page of this work, and whose helpful advice and constructive suggestions are deeply appreciated.

To Kathryn Cash, who tirelessly edited and typed the rough drafts, and to Marley Soper, director of the library and his staff, for their many special concessions in the busy days of final writing, grateful thanks are given.

To the administrators of the South American Division who kindly responded to the questionnaire, I owe a debt of gratitude. Any merit this project might have is due to the above-named persons and the many others who have contributed their time and suggestions. 


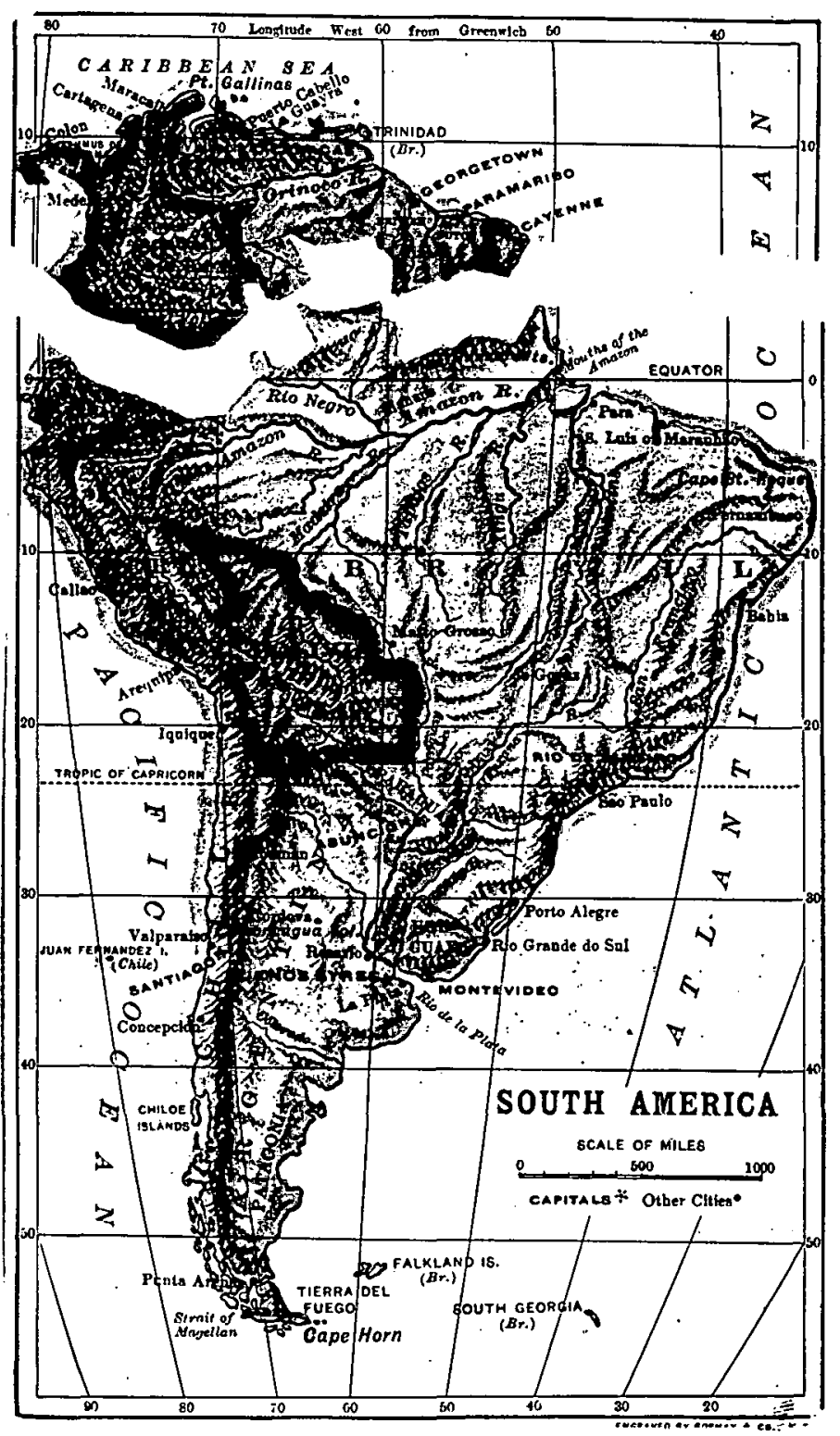




\section{PART I}

IMAGES OF THE CHURCH AS RELATED TO EFFECTIVENESS IN MINISTRY 
CHAPTER I

INTRODUCTION

\section{Statement of the Problem}

The productivity of the minister has been much discussed and emphasized in the Seventh-day Adventist church in South America. Unfortunately, in several areas at least, productivity in ministry has been largely measured in numerical achievements. As a result, in our opinion, the qualitative aspects of ministry have suffered and sometimes been almost totally sacrificed.

It became apparent that ministers who reached the numerical goals set by the administration were frequently ordained earlier than those who did not, or were "promoted" to administrative positions. It also was observed that ministers who did not reach the goals were moved more frequently. This made long-term planning virtualiy impossible for them and often endangered family relationships and disturbed the education of the children, thus promoting a generalized instability for the whole family. It seemed that in order for a minister to be considered successful by the leadership of his church, his number-one priority had to be reaching what had become the all-important goal--the baptismal goal. This became a very real source of frustration for those ministers conscious of sounder and wider principles of ministerial responsibilities On the local church level the pastor was too of ten caught in 
the crossfire of conflicting expectations. On the one hand he experienced the subtle--and sometimes not so subtle--pressures from the administration for numerical achievements. On the other hand, he felt the concerns of his church for an integral qualitative ministry that would result in fewer apostasies and strengthen the longterm stability of the church.

\section{Justification for the Study}

In light of the above-stated problem, one great need is starkly exposed: both ministers and administrators need to arrive at a clear understanding of ministerial productivity. Such an understanding would have to be grounded in the Scriptures and the writings of Ellen G. White, inasmuch as Seventh-day Adventists accept White's writings as inspired counsel for the church.'

By identifying and evaluating God's criteria governing pastoral productivity, it was anticipated that such a study might contribute not only to an awareness of a more balanced system of evaluating ministerial productivity for Seventh-day Adventist pastors in South America but may also (1) produce a more positive image of the ministry; (2) reduce the tensions existing between the local church, the minister, and the administration; and (3) facilitate the implementation and achievement of long-range qualitative and quantitative goals and objectives rather than the concentration on short-range, more measurable accomplishments.

l"Ellen Gould (Harmon) White (1827-1915), cofounder of the SDA Church, writer, lecturer, and counselor to the church, who possessed what SDA's have accepted as the prophetic gift described in the Bible" (Don N. Neufeld, ed., Seventh-day Adventist Encyclopedia [Washington, D.C.: Review and Herald Publishing Assoc., 1976], s.v. "White, Ellen"). 


\section{Definition of Terms}

Productivity in ministry. The word "productivity" will

be interchanged with effectiveness meaning, vitality, healthfulness, sufficiency, and proficiency.

Vital mission. The vital mission of the church as used in this study involves those aspects of the mission of the church pertaining to the basic spiritual life--the responsibility of its members to engage in true worship, to demonstrate obedience to God, and to manifest devotion toward one another. In other words, "vital mission" concerns itself with the spiritual vitality of an inner Christian experience on both an individual and corporate level.

Organic mission. The organic mission of the church as used here pertains to the enabling of members according to their talents and spiritual gifts. It aims to foster spiritual health, unity, and maturation of the members through Christian nurture, fellowship, and education.

Expansional mission. The expansional mission of the church. refers to the out-reach or missionary program of the church in fulfillment of the gospel commission. It consists of the external mission of the church.

Qualitative productivity. Qualitative productivity refers to those lasting, in-depth aspects of the quality of congregational life. "Qualitative" in this context connotes dependability, something sterling and true in contrast to what may appear on the surface 
to be such but turns out to be undependable and shallow.

Quantitative productivity. Quantitative productivity is the measurement of productivity in numerical or statistical terms.

South American Division/SAD refers to a large unit of church organization which includes all of South America except for the countries of Colombia, Venezuela, and the Guianas.

\section{Overview}

This study consists of two parts: (1) a theological position paper, and (2) a statement of application. The first attempts to arrive at an understanding of the nature and mission of the church through examining images of the church and the minister and/or ministry in the Bible and the writings of Ellen G. White, as well as reviewing other pertinent literature and research. From such an examination will be drawn (1) basic principles governing productivity, (2) personal qualifications of ministers that enhance productivity and the performance of ministerial roles leading to productivity; and (3) criteria for evaluating the productivity of ministry qualitatively and quantitatively.

In the second part of this paper practical application of these discoveries is made to findings with respect to ministerial productivity as viewed by church leaders in the South American Division of Seventh-day Adventists. Recommendations emerging from the data are offered regarding strategies for evaluating and enhancing productivity in ministry. 
CHAṔTER II

TOWARD A THEOLOGICAL UNDERSTANDING OF

\section{- EFFECTIVENESS IN MINISTRY}

This chapter is a brief overview of the nature and mission of the church as depicted in the Bible, the writings of Ellen $G$. White, and other contemporary theologians. Ministry in the church should be closely related to our understanding of the nature of the church. Likewise, productivity in ministry must be considered in the framework of the nature and mission of the church. This overview provides the basic background for the study.

\section{The Nature of the Church}

The church is a complex entity with a variety of spiritual, social, and organizational aspects. Minear claims that "the church does not have a nature that can be readily defined simply by looking, no matter how directly, at the church itself." 1 Jesus said almost nothing about the church. In fact, the word "church" (ekklesia) appears only twice in the gospels (Matt 16:18;18:17).2

Dulles makes the statement that "the Bible, when it seeks to illuminate the nature of the Church, speaks almost entirely through

${ }^{1}$ Paul Minear, Images of the Church in the New Testament (Philadelphia: Westminster Press, 1960), p. 12.

${ }^{2}$ A11 Bible quotations are taken from the Revised Standard Version unless otherwise stated. 
images," such as the building raised up by Christ, the house of God, the temple of God, His people, His flock, His vine, His field, His city, the pillar of truth, and finally, the bride of Christ and His mystical body. 1 White portrays the church as a "channel of 1 ight," "His [the Lord's] garden," the "army of Prince Emmanuel," "the guardian of the treasures of truth," "the court of holy life," and others. 2

Hans Küng correctly points out that

Our concept of the Church is basically influenced by the form of the Church at any given time. . . Every age has its own image of the Church, arising out of a particular historical situation. . . . At the same time there is a constant factor in the various changing historical images of the Church, something which survives however much the history of mankind, of the Church and of theology may vary. 3

Since the nature of the church seems to be best understood through images, at this point it is well to examine a few of those images that best contribute to an understanding of productivity in ministry.

\section{Biblical Images}

The bride of Christ. The church as the bride of Christ is one of the beautiful analogies in the Bible. Through the symbol of

1Avery S. J. Dulles, Models of the Church (Garden City, NJ: Doubleday \& Company, 1974), p. 17.

${ }^{2}$ Ellen G. White, Testimonies for the Church, 9 vols. (Mountain View, CA: Pacific Press Pub. Assn., 1948), 3:414; idem., Evangel ism (Washington, D.C.: Review \& Herald Pub. Assn., 1946), p. 98; idem., Testimonies, 9:116; idem., Great Controversy (Mounta in View, CA: Pacific Press Pub. Assn., 1911), p. 64; idem., Acts of the Apostles (Mountain View, CA: Pacific Press Pub. Assn., 1911), p. 12 .

The Church (New York: Sheed and Ward, 1967), pp. 4; 5. 
the marriage relationship God portrays the closeness He desires to have with His church. Commenting on this, White states that "in the Bible, the sacred and enduring character is represented by the union of marriage. The Lord has joined His people to Himself." 1 In this setting, OT prophets depicted apostasy as divorce and spiritual prostitution (Isa 62:4-5; Jer 3:1-2; Hos 2:19), and NT writers portray the great potential of the church as Christ's bride (Eph 5:23-25; Rev 19:7-9).

It appears that in the closeness of the sacred marriage relationship is unfolded the significance for the church of an atmosphere of love, moral purity, and spiritual fidelity to Christ as the Bridegroom.

It is obvious from this that one dimension of pastoral responsibility one might legitimately infer is that the pastor will lead the church into experiences of spiritual development and worship appropriate to the ideal represented by this image of the church as Christ's bride. The pastor's success in achieving this might then be seen as one measure of productivity as defined in this paper.

The people of God. It is Costas' contention that the foremost image of the church in Scripture is that of God's people. ${ }^{2}$ The deep historical roots of this symbolism reach back to Eden (Gen 3:14-15). Thereafter a continuous thread runs through the

\section{1}

Great Controversy, p. 381.

${ }^{2}$ Orlando E. Costas, The Church and Its Mission: A Shattering Critique from the Third World (Wheaton, IL: Tyndale House Pub., 1974), p. 23. 
centuries confirming God's desire for a special people for Himself

(Gen $6: 18 ; 9: 9 ; 12: 1-3 ; 22: 18$; Exod $6: 5-7 ; 19: 5-6$; Deut $7: 6$;

29:12-13; Ps 89:4; Isa 10:21-23; Acts 2:4-36; Rom 9:27) and culminating in the "chosen race," "royal priesthood," and "holy nation" concept of 1 Pet 2:9-10. 0osterwal succinctly summarizes the church as God's people in these words:

It is surely a fact of inexhaustible significance that what our Lord left behind $\mathrm{Him}$ when He ascended from earth was not a book, not a creed, not a system of thought, not a rule of life, but a visible community called and gathered by Him through a deliberate choice on His part. ${ }^{1}$

This community was called into existence to make known

God's love and, in the words of Lindgren,

. . this is to be done not just by priests or by individuals, but through the witness of the entire church community. The corporate nature of the church is clearly indicated in a passage such as Eph. 2:19, "So then you are no longer strangers and sojourners, but you are fellow citizens with the saints and members of the household of God." . . . No Christian stands alone. Each is a part of a fellowship, a household, a community. In summary, to say that the church is "God's chosen people" means that it is initiated by God; that it is chosen for a purpose, that of making known God's love; and that the divine task belongs to all members of the chosen community. 2

Productivity in ministry, one might infer, would involve success in leading a community of believers in identifying and responding to God's original purpose of calling out a people, a community of believers for Himself.

Christ Himself initiated the ministry for the people of God

1Walter B. T. Douglas, "The Church: Its Nature and Function," Servants for Christ: The Adventist Church Facing the ' 80 s (Berrien Springs, MI: Andrews University Press, 1980), pp. 70-71.

${ }^{2}$ Alvin Lindgren, Foundations for Purposeful Church Administration (Nashville: Abingdon Press, 1978), p. 43. 
by choosing disciples to serve as shepherds of the flock (Luke $6: 12-16$; Acts $20: 28$ ). The work of the ministry is today--and ever has been--"to embrace all that was embraced in Christ's ministry" (Matt 28:20); therefore careful study must be given to Christ's methods of labor, which "alone will give true success in reaching the people." 2 The nurture of the people of God is a continuous process in the formation of God's temple, the subject of the next image.

The temple of God. "We are ... God's building. ... You are God's temple! (I Cor. $3: 9,16$ ). ${ }^{3}$ This analogy obviously points back to the tabernacle and/or temple of the OT. Peter and John portray church members as "living stones" in this temple structure (1 Pet $2: 4-5 ; \operatorname{Rev} 1: 6$ ), of which the foundation, or cornerstone, is Christ (Matt $16: 18 ; 21: 42 ; 1$ Cor $3: 11 ; 1$ Pet 2:6-8; Isa 28:16). Of this cornerstone White states: "It is broad enough for a11, and strong enough to sustain the weight and burden of the whole world." 4 Watson suggests that the living stones need to be cemented together by love and trust. Each must find his right place in the structure and each is vitally important. ${ }^{5}$ White further contends that "through the ages that have passed since the

White, Testimonies, $6: 301$.

${ }^{2}$ Ellen G. White, Gospel Workers (Washington, D.C.: Review \& Herald Pub. Assn., 1915), p. 363.

${ }^{3}$ David Watson, I Believe in the Church (Grand Rapids: Wm. B. Eerdmans, 1978), p. 51 .

${ }^{4}$ Ellen G. White, Desire of Ages (Mountain View, CA: Pacific Press Pub. Assn., 1955), pp. 598-99.

${ }^{5}$ Watson, I Believe in the Church, p. 125. 
days of the apostles, the building of God's temple has never ceased." 1

It is the minister's privilege to help fashion rough-stone characters into living, shining stones for God's temple, linking each one to himself, to others, and to Christ, the Foundation Stone. The fruitful minister binds his members together in love and truth, that the portion of God's temple under his workmanship may conform to the divine pattern.

The body of Christ. Perhaps more than any other metaphor, the church as the body of Christ suggests its spiritual and functional reality as a corporate personality. In 1 Cor 12:1-26 Paul deals with unity in diversity. Dederen explains that

- . Christian unity, to be sure, does not mean uniformity to us. Christian unity involves diversity, such as variations in worship as well as in forms of organization. This very diversity adds interest and beauty to the life of the body. At the same time, however, we hold that Jesus' request "as we are" calls for a fellowship in spirit, mind, and character in which Christians are to be one.?

Lindgren adds the reminder that such fellowship involves corporate interdependence on the part of each church member, ${ }^{3}$ which is, of course, clearly apparent in the figure of a body.

Only when the corporate church lives in unity and humility under the divine guidance of its head, Jesus Christ, can it grow and be sanctified by Christ until it is holy and without blemish

IActs of the Apostles, p. 598.

2 Raou1 Dederen, "The Nature of the Church," Ministry, February 1978 (supplement), p. 24.

$3^{3}$ Foundations for Purposeful Church Administration, p. 48. 
(Eph 5:26-27). White elaborates on this growth process implicit

in the church-as-a-body image.

We are members of His mystical body. He is the head, controlling all the members of the body. Jesus Himself, in His infinite mercy, is working on human hearts, effecting spiritual transformations so amazing that angels look on with astonishment and joy.

Richards depicts the healthy growth process of the living church organism:

When the church is living in intimate relationship with Christ, "from whom the whole body, supported and held together by its ligaments and sinews, [it] grows as God causes it to grow" (Col. 2:19).

What is important to realize is that "growth" in Scripture relates almost always to internal growth toward maturity. 2

In Eph 4:4-13 Paul applies the purpose of spiritual gifts in the body of Christ, again emphasizing the unity in diversity aspect. Thus it can be seen that the main aspect of the church as the body of Christ is unity in diversity, the healthy growth of both the individual parts and the corporate living church organism, and the equipping of the saints through spiritual gifts for both organic and expansion growth.

This image of the church as the body of Christ suggests among other things that the minister is able to unify the diverse spiritual gifts of parishioners without forcing uniformity, to foster fellowship and interdependence by strengthening the abilities of each person to function cooperatively under Christ's leadership.

It might be inferred that evaluation of the minister include

Testimonies, $5: 731$.

2Lawrence 0 . Richards and Clyde Hoeldke, A Theology of Church Leadership (Grand Rapids: Zondervans, 1980), p. 44. 
examination of his flexibility (unity in diversity), as well as his abilities to foster fellowship and personal and corporate growth through encouragement and training with respect to spiritual gifts in the body of church members.

From the graphic Scriptural images attention is now turned to two unique images from the pen of Ellen G. White.

Images in the Writings of Ellen G. White

The garden of God. "The church is a garden." 1 This image depicts the entire world as a large, colorful garden in which there is a variety of flowers, each with its own peculiarities and each with its own value. As plants and flowers in a garden respond to the will and purposes: of the gardener, so must the garden/church respond to the will and purposes of the Divine Gardener. As plants receive light and life from God and produce fruit and flowers of many shapes, textures, perfumes, and colors, so the beauty of God's spiritual garden lies in a variety of natural talents and spiritual gifts functioning harmoniously as a church. ${ }^{2}$

The concepts for evaluating the minister's productivity that emerge from the garden-of-the-Lord imagery, overlap several already covered. However, aesthetic and utilitarian elements are suggested including a solicitous nurturing and training of the plants in God's garden.

The army of Prince Emmanuel. "The church of Christ may be

$1_{\text {White, Testimonies, }} 6: 333$. White, Evangelism, p. 99. 
fitly compared to an army. The life of every soldier is one of toil, hardship, and danger." 1 It is emphasized that "the strength of an army is measured largely by the efficiency of the men in the ranks" 2 and that the "General, who has never lost a battle, expects willing, faithful service from everyone who has enlisted under His banner. " 3 Under the guidance of their Commander-in-Chief, White sees that the church, "armed with the omnipotence of the Holy Spirit, would conquer in the battle with evil, and that the blood-stained banner [of Emmanuel] would one day wave triumphantly over His followers. "4 One might conclude from this imagery that a successful pastor. would demonstrate in his leadership and administration the ordered efficiency that characterizes a well-disciplined army. There would be efficiency in leading a congregation in planning mission strategies and achieving mission goals.

These images of the church help us to understand the purpose of the church--a study of which also yields suggestions for the mission of its pastoral leadership. Another way to consider criteria for ministry is to examine the mission of the church.

\section{The Mission of the Church}

According to Oosterwal, "Christ established His church for a missionary purpose. . . I Itself the fruit of God's mission of love, the church is His agency for the salvation of men." 5 This

'White, Testimonies, 5:394. 2 Ibid., 9:116. 3 ${ }^{3}$ Ibid.

${ }^{4}$ Acts of the Apostles, p. 21.

${ }^{5}$ Gottfried Oosterwal, Mission: Possible (Nashville: Southern Pub. Assn., 1972), p. 69. 
mission was outlined by none other than the Lord Jesus Christ in simple words so explicit and commanding they have echoed down the centuries with no loss of urgency or force:

Go therefore and make disciples of all nations, baptizing them in the name of the Father and of the Son and of the Holy Spirit, teaching them to observe all that I have commanded you; and 10, I am with you always, to the close of the age. (Matt 28:19-20)

The mission of the church may be better understood dynamically by considering it in three directions: its vital mission, which centers on the church's relationship toward God (worship, obedience, etc.); its organic mission, which focuses on the church's mission toward itself; and its expansional mission, which constitutes its mission to the world. Admittedly, these three missions are closely interrelated and interdependent, yet the distinctiveness of each contributes to an understanding of the mission of the church as a whole and to an understanding of the requirements for effective ministry.

The Vital Mission of the Church

By the vital mission of the church we refer to the church's responses to God's continual efforts to lift the human soul toward Himself. Consequently it is a mission that calls for individuality among the collectivity. "At the cherubim-guarded gate of Paradise the glory of God was revealed, and hither came the first worshipers, "I states White. Noah's first act after leaving the ark was worship; he erected an altar and offered a sacrifice (Gen 8:20). Abraham,

${ }^{1}$ Ellen G. White, Patriarchs and Prophets (Mountain View, CA: Pacific Press Pub. Assn., 1958), pp. 83-84. 
Isaac, and Jacob constructed altars wherever they camped. At Sinai God instructed Israel to erect a sanctuary for individual and corporate worship (Exod 25-31). For the same purpose the permanent temple was later built in Jerusalem (Ps 5:7; 138:2). Jesus emphatically pointed out, however, the difference between a place of worship and true worship. "True worshippers will worship the Father in spirit and truth" (John 4:23). His followers, therefore, will keep this distinction uppermost as they seek to glorify God through worship.

The challenge of the church's vital mission is to lead the membership to a spiritual responsiveness toward God such that they, like Enoch, will live "in the very atmosphere of heaven." 1 This requires the minister to structure an appropriate and inspiring worship service including a well-rounded preaching program, as well as to give attention to other aspects of the worship services, such as music, decor, and physical properties (lighting, ventilation, etc.) adapted to the circumstances and special needs of the worshippers. Only to the degree that this is accomplished will the organic and expansional missions of the church be meaningful and effective.

The Organic Mission of the Church

Although the church partakes of the characteristics of a human organization, ${ }^{2}$ it must be seen as a human institution under

$$
\text { I Ibid., p. } 85 .
$$

2 Richards and Hoeldtke, A Theology of Church Leadership, pp. $45-46$. 
God. Its organic nature as the body of Christ with all that this concept implies theologically must be emphasized. The organic or internal mission of the church helps to lead its members toward spiritual growth that is from God" ( $\operatorname{Col} 2: 19)$ to the "stature of the fulness of Christ" (Eph 4:15). To become teleios (Greek for "mature") involves a two-way nurturing process--vertical fellowship with God (1 Cor 1:9) and horizontal fellowship with one another. While the first "is the most weighty trust and the highest honor," 1 the latter is no less important. "God wants His people to be united in the closest bonds of Christian fellowship."2

The process of growth in the body involves the mutual contribution of every member that the whole might be built up (oikodomeō) and achieve maturity. . . .

Ephesians 4 .. : shows us clearly how internal growth takes place. We are shown a living body, supplied by Jesus Christ with leaders who are charged to prepare God's people for their work of building up the body. It is the people of God who, in ministering to each other, are the agents God uses to supply all that is needed for internal growth. ${ }^{3}$

This fellowship is the soil from which the other conditions operant in the organic prosperity of the church spring forth, the foremost of which are, perhaps, talents and spiritual gifts for mutual ministry. Productive ministers discern, cultivate, and educate the talents and spiritual gifts of their members so that every believer grows daily in usefulness in the ministries of the church and to the church.

The organic mission of the church never ceases. When it is

\footnotetext{
Thite, Desire of Ages, p. 225.

2 White, Testimonies, 3:446.

${ }^{3}$ Richards and Hoeldtke, A Theology of Church Leadership, pp. $46-47$.
} 
successful the church is able to engage purposefully in the expansional mission of the church. And it forms a cycle; as the expansional mission increases, the organic mission is strengthened.

\section{The Expansional Mission} of the Church

Christ commanded His followers to make disciples of all nations (Matt 28:18). This command constitutes the expansional mission of the church--the "great missionary charter of Christ's kingdom." In his last prayer with His disciples, Jesus included "those who believe in me through their [the disciples'] word" (John 17:20). Only through the priesthood of all believers will the "word" be preached. There is no alternative. "The work which the disciples did, we also are to do." 2

Every addition to the church should be one more agency for the carrying out of the great plan of redemption. The entire church, acting as one, blending in perfect union, is to be a living, active missionary agency, moved and controlled by the Holy Spirit. 3

Jesus told the disciples to remain in the city until they received the Holy Spirit (Luke 24:49), after which they were to begin witnessing in Jerusalem, proceed to Judea and Samaria, and finally spread out to the entire world. These instructions are pregnant with meaning for the church today. The first mission field for every believer is his own Jerusalem-neighborhood--his family, neighbors, school, and work associates. "The gospel invitation is to be

IEllen G. White, Christian Service (Washington, D.C.: Home Missionary Department of the General Conference of Seventh-day Adventists, 1947), p. 23.

$$
\text { 2Ibid., p. 22. 3White, Testimonies, } 8: 47 \text {. }
$$


given to the rich and the poor, the high and the low, and we must devise means for carrying the truth into new places, and to all classes of people." 1

The world is a colorful mosaic of diverse groupings: sociological, economical, political, cultural, linguistic, religious, consanguinal, racial, and geographical. Each frontier, of whatever kind, has to be crossed in the fulfilling of the missionary task.?

With this White concurs: "Our General . . says to us: 'Advance. Enter new territory. Lift up the standard in every land'."3

The foregoing requires productive ministers who will foster increase by reaching out through every Spirit-filled believer. The logic is incontrovertible: the more effective the outreach, the greater the numerical increase; the higher the quality of the mission, the fewer dropouts; the higher the combined qualitative and quantitative increase, the higher the minister's productivity.

\section{Summary}

Since the church, spiritual by nature, has a depth of meaning not readily defined, it is best understood through biblical images. The waiting Bridegroom, the people of God, the coordinating Head of Christ's body, the supporting Cornerstone of the temple of God, the experienced Gardener, the army of God, all converge on Christ as the center of the church.

The church was organized and designed to grow and multiply. It is irretrievably involved in warfare--the great controversy

\footnotetext{
lWhite, Evangel ism, p. 552.

${ }^{2}$ Gottfried Oosterwal, "The Mission of the Church 1972," Ministry, July 1972 (supplement), p. 24H.

3 Testimonies, $6: 28-29$.
} 
between good and evil. Its members can best reveal God's redemptive love through lives that have been transformed by the Redeemer and a corresponding active personal and corporate outreach. The disciples' commission, given them by Christ in His final moments with them, enjoins them, through the Holy Spirit, to make disciples for Christ. To accomplish this the church is, first and foremost, to be rooted in Christ. This, in turn, enables it to promote personal and corporate worship grounded on truth (the vital mission); to develop obedience through faith, to enhance both horizontal and vertical fellowship, to foster unity with diversity, cohesiveness with individuality, and to discern and develop talents and spiritual gifts in its midst (the organic mission); and to recognize and carry out its varied ministries of outreach (the expansional mission).

Specific criteria for pastoral productivity which emerge from this picture would include: success in leading congregations in worship and spiritual development; success in leading a congregation in evangelistic outreach, success in leading a congregation in identifying, coordinating, and employing gifts for ministry; and efficiency in planning, organizing, and leading a congregation in achieving mission strategies and goals. 


\section{CHAPTER - I I I}

\section{BIBLICAL AND ELLEN G. WHITE CRITERIA OF PERSONAL QUALIFICATIONS OF MINISTERS}

Even as criteria for productivity in ministry must be grounded in an understanding of the nature and mission of the church, so personal qualifications for productivity in ministry of necessity must also be in harmony with the spiritual nature and mission of the church and in accordance with basic principles governing productivity. In an indirect way one may infer criteria for measuring effectiveness for ministry from these qualifications outlined in Scripture.

Purkiser suggests that certain basic characterizations of the ministry find expression in the NT, such as the ministry as a calling, a covenant, a commitment, a commission, a consecration, a challenge, and a continuation of Christ's mission. ${ }^{1}$ White adds that it involves reformation. $^{2}$ These characterizations of ministry suggest basic attitudes with which the minister must approach his work, which in turn must be undergirded by specific gifts and talents.

\section{The Divine Call}

The minister is "called by God" (Heb 5:4) through varied ways and circumstances. Abram's call came from the Lord through an

$1_{\text {W. T. Purkiser, The New Testament Image of the Ministry }}$ (Kansas City: Beacon Hill Press, 1969), pp. 22-29, passim.

2 Evangelism. 
imperative: "Go from your country" (Gen 12:1), and "by faith Abraham obeyed when he was called to go" (Heb 11:8). On this White elaborates:

Abraham was called to go forth from his home, a lightbearer to the heathen. And without questioning, he obeyed. . . So today God's servants are to go where He calls, trusting Him to guide them and to give them success in their work. $]$

Moses was called through the divine Presence in a flaming bush. God called him by name and said, "Come, I will send you to Pharaoh that you may bring forth my people. . . Say this to the people of Israel, 'I am has sent me'" (Exod 3:10, 14). According to White, "Today God chooses men as He chose Moses, to be His messengers, and heavy is the woe resting on the one who dishonors his holy calling, or lowers the standard set for him in the life and labors of the Son of God." 2

Samson's call was communicated by an angel (Judg 13:24-25). Reiswig comments:

Samson failed to recognize the sacredness of the work to which he was called. He depended upon his own strength to accomplish it. God had a definite program for Samson, but he chose his own course. The ministry of the Seventh-day Adventist denomination today has a similar call. We too are to deliver a people out of the bondage of $\sin .3$

The prophet Isaiah received his call through a vision. His mouth and lips were touched by a burning coal, his guilt taken away, his sins forgiven, and then he answered the Lord's call by saying, "Here am I! send me" (Isa 6:1-8).

${ }^{1}$ Gospel Workers, p. $26 . \ldots, 2$ Ibid., p. 20.

3J. J. Reiswig, "The Holy Calling of the Ministry," Ministry, February 1952, p. 5. 
- . He felt altogether inefficient and unworthy. . . If, like Isaiah, they [God's ministers] humble their hearts before God, the work done for the prophet will be performed for them. Their lips will be touched with a live coal from off the altar, and they will lose sight of self in a sense of the greatness and power of God and His readiness to help them... .

The live coal is symbolical of purification and it also represents the potency of the efforts of God's true servants.

Christ Himself was called of God (Heb 5:5, 10). Evans reminds us that He was not only called of God, but was also visibly anointed by the Holy Spirit (Matt $3: 16,17) .^{2}$

Christ's first disciples were called after a great fishing miracle: "'Follow me, and I will make you fishers of men' and immediately they... followed Him" (Matt 4:19). Christ "called to him those whom He desired;.... and he appointed twelve to be with him, and to be sent out to preach" (Mark 3:13-14). White comments that "all the disciples had serious faults when Jesus called them to His service, " ${ }^{3}$ but

... By practicing His virtues, by walking and working with Him, they were to be qualified to be fishers of men. $\therefore$ By the simplicity of faith, by pure, humble service, the disciples were taught to carry responsibilities in God's cause.

. . They bound themselves up with the mightiest of all powers, and were ever longing for a deeper, higher, broader comprehension of eternal realities, that they might successfulty present the treasures of truth to a needy world. 4

Paul's cal1, "by the will of God" (1 Cor 1:1) was so dramatic that he could not doubt its divine source (Acts 9:1-30). Froom assures:

$1_{\text {Whit te, Gospel Workers, }}$ pp. 21-23.

2 Irvin Henry Evans, The Preacher and His Preaching (Washington, D.C.: Review and Herald Pub. Assn., 1938), pp. 37-38.

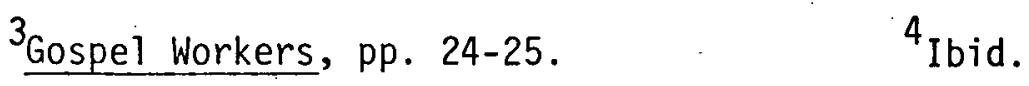


Again and again Paul states succinctly the certainty of the divine origin and nature of his call to the ministry. Hear him: "Paul, a servant of Jesus Christ, called to be an apostle, separated unto the gospel of God" (Rom. 1:1); "Paul, called to be an apostle of Jesus Christ through the will of God" (1 Cor. 1:1; also 2 Cor. 1:1; Eph. 1:1; Col. 1:1; 2 Tim. 1:1); "Paul, an apostle, (not of men, neither by man, but by Jesus Christ, and God the Father)" (Gal. 1:1); "I thank Christ Jesus our Lord, who hath enabled me, . . putting me into the ministry" (1 Tim. 1:12); "whereof I am made a minister, according to the dispensation of God which is given to me for you, to fulfill the word of God." Col. 1:25. (Emphas is supplied.)

Cleveland points out that not all calls are a dramatic Damascus-way experience. The Lord knows whom He wants and how best to secure him. ${ }^{2}$ Yet White argues that "God has repeatedly shown that persons should not be encouraged into the field without unmistakable evidence that He has called them. The Lord will not entrust the burden for his flock to unqualified individuals. " ${ }^{3}$ Haynes stresses,

Every call of God has its own uniqueness. No two are alike. I am not contending for similarity of method, but rather certainty that the call is from God. In all of them, if they are genuine calls, there is a sense of divine origin, a solemn communication of the divine will, a mysterious sense of commission, a strong feeling of compulsion, all of which leaves a man no alternative, but starts him out on the road of this vocation with a conviction that he is an instrument and an ambassador of the Eternal God. 4

White states that ministers are "chosen of God, sealed with the blood of consecration. ${ }^{5}$ Cleveland states briefly, "Ministers

'Leroy Edwin Froom, "The Ministerial Call and Calling," Ministry, November 1940, p. 22. 1959 , p. 46.

2Earl E. Cleveland, "Who Put You In?" Ministry, January

3

Testimonies, 1:209.

${ }^{4}$ Carlyle B. Haynes, "Called of God--Are You Sure!" Ministry, January 1955 , p. 8.

${ }^{5}$ Gospel Workers, p. 15. 
are God-called, God-actuated messengers of Jehovah." 1 other writers view such a call with awe: "Ordained by God . . . ! Called of God! Preachers are a special product of the divine saving grace of Jesus Christ." 2 Willis considers that "God has a definite purpose and men are called to a definite work. ${ }^{3}$

Froom finds four Biblical evidences of a divine call:

1. An inner conviction wrought in varying ways by the Holy Spirit.

2. An outward convergence of providential circumstances.

3. The approving judgment and ordaining action of the church.

4. The witness of fruit from one's labors.

. . We may say that the true minister of Jesus Christ is called of God (Acts 13:2), is separated unto the gospel

(Rom. $1: 1$ ), is qualified by God ( 2 Cor. $3: 5,6)$, has authority from God (2 Cor. 13:10), is commissioned by Christ (Matt. 28:19,20), and is sent by the Holy Spirit (Acts 13:2,4).4 (Emphasis supplied)

In Bietz' opinion,

Once we have experienced the call, we should not hesitate to lay claim on being God's emissaries. We should not be uncertain or timid about feeling that God has called us. . . We can be confident yet modest. As someone said, "One walks then with a firm tread, lifted carriage, and steady eye, showing the ministry to be a delight no matter what comes or does not come." 5

It seems reasonable, according to the nature and mission of the church, to regard a divine call as the supreme qualification

${ }^{1}$ Earl E. Cleveland, "The Decline of the Ministry," Ministry, December 1969, p. 5.

2B. E. Hassenpflug, "Your Call to the Word of God," Ministry, August 1953, p. 8.

${ }^{3}$ Craig S. Willis, The Art of Preaching (Adventist Seminary of West Africa, mimeographed, n.d.), p. 4.

4 "The Ministerial Call and Calling," p. 24.

${ }^{5}$ Reinhold R. Bietz, "The Minister's Calling, Work, and Responsibility," Ministry, August 1954, p. 12. 
for a successful minister. Obviously, an effective minister will go about his work with a stabilizing sense of claim and conviction. The difficulties and trials of his work will not deter him from the pursuit of the vision and conviction of his calling. The next " requirement qualifying one for ministry, closely related to it and one which validates the call, is the enabling presence of the Holy Spirit.

\section{The Holy Spirit (Baptism)}

One of Christ's last promises to His disciples was, "You shall be baptized with the Holy Spirit" (Acts 1:5). White affirms: "Christ comes with His own redeeming influence, proposing through the agency of His Spirit to impart His efficiency to men, and to employ them as His instrumentalities." 1 The promise is: "You shall receive power when the Holy Spirit has come upon you; and you shall be my witnesses" (Acts 1:8). "The presence of the Spirit with God's workers will give the presentation of the truth a power that not all the honor or glory of the world could give. . . ." "Under the Spirit's teaching, they [the disciples] received the final qualification, and went forth to their lifework." 3

It is the efficiency of the Holy Spirit that makes the ministry of the word effective. When Christ speaks through the minister, the Holy Spirit prepares the hearts of the listeners to receive the word. The Holy Spirit is not a servant, but a controlling power. He causes the truth to shine into minds, and speaks through every discourse where the minister surrenders himself to the divine working. It is the Spirit that surrounds the soul with a holy atmosphere,

Testimonies, 6:238.

${ }^{2}$ Ibid., $8: 22$.

${ }^{3}$ Idem., Acts of the Aposties, p. 45. 
and speaks to the impenitent through words of warning, pointing them to Him who takes away the sin of the world.?

Reeves concludes that the supreme qualification for effectual ministry is "a real baptism by the Holy Spirit. . . [which] will turn dry, lifeless communities into fruitful, flourishing centers of spiritual activity." ${ }^{2}$ In brief, it is the efficiency of the daily baptism of the Holy Spirit that makes and maintains the minister's sense of vocation so strongly that his ministry naturally reflects the ministries demonstrated by Christ and His disciples, and without which all other qualifications would be meaningless.

\section{Personal Qualifications}

From Paul's letters to the Galatians, Timothy, and Titus, a list of nearly thirty basic qualifications for mature and productive ministry may be derived: above reproach, able to teach, devout, faithful, free from the love of money, gentle, good, husband of one wife, hospitable, joyful, just, kind, lovely, loving what is good, not given to wine, not self-willed, not quick-tempered, not pugnacious, not a new convert, managing his own household we11, patient, peaceable, prudent, respectable, self-controlled, temperate, and uncontentious (Gal $5: 22-23 ; 1$ Tim $3: 1-7$; Titus $1: 5-10$ ). In this vein, White challenges:

At this time God's cause is in need of men and women who possess rare qualifications and good administrative powers; men and women who will make patient, thorough investigation of the needs of the work in various fields; those who have a large capacity for work; those who possess warm, kind hearts,

IIdem., Gospel Workers, p. 155.

${ }^{2} \mathrm{C}$. Angus Reeves, "The One Supreme Qualification," Ministry, October 1938, p. 14. 
cool heads, sound sense, and unbiased judgment, those who are sanctified by the Spirit of God and can fearlessiy say, No, or Yea and Amen, to propositions; those who have strong convictions, clear understanding, and pure, sympathetic hearts; those who practice the words, "All ye are brethren"; those who strive to uplift and restore fallen humanity.

These lists of qualifications by Paul and White are interrelated and interdependent descriptive characterizations of ministry as referred to below. They provide further clues with respect to personal dimensions to be expected within which an effective ministry may take place.

\section{Characterizations of Ministry}

The ministry as a covenant. Paul speaks of ministers in terms of being "ministers of a new covenant" ( 2 Cor 3:6; see also Jer $31: 31-34 ; 1$ Cor 1:24-26; Heb 8:8-12). In addition, from the review of how God called individuals in Bible times, it is evident that He called men to enter into covenant relationship with Him, to minister "the new and living way" "by the blood of Jesus" (Heb 10: 16-21), from whom they received their sufficiency for ministry (2 Cor 3:4-6). After stating that the call to ministry today is a call "to be ministers of a new covenant," Bartlett claims,

Perhaps we shall be no less active in our ministry, but it will be the activity of assurance, not that of anxiety. We even may do many of the same things which mark the pastorate today, but they will be meaningful, taking on a new sacramental nature. At least we shall be able to bring a whole man to the proclaiming of the whole gospel.2

\section{Testimonies, $7: 249$,}

${ }^{2}$ Gene E. Bartlett, The Audacity of Preaching (New York: Harper and Brothers, 1962), pp. 34-35, quoted in Purkiser, The New Testament Images of the Ministry, pp. 23-24. 
The ministry as commitment. The Biblical concept of covenant always originates with God's initiative, yet it requires a choice, a commitment on the part of those to whom it is offered. "Call and covenant find completion only in choice, commitment to the purpose of God," stresses Purkiser. 1 To this White adds, Ministers . . are Christ's shepherds. He has appointed them under himself to oversee and tend his flock. He has solemly commanded these to be faithful shepherds, to feed the flock with diligence, to follow his example, to strengthen the weak, nourish the fainting, and to shield them from devouring beasts. . . The flock will prosper under their care. ${ }^{2}$

The ministry as a commission. It is the privilege and obligation of the church, through the Holy Spirit's orientation, to confirm the minister's call by recognizing the gifts and graces God has bestowed upon him. The church at Antioch was instructed by the Holy Spirit to set apart Barnabas and Saul for the work to which they had been called (Acts 13:2). Ministers are men "sent [commissioned] from God" (John 1:6) to "make disciples" (Matt 28:19), to be "ambassadors for Christ" (2 Cor 5:20). White emphasizes that "the commission given to the disciples is given also to us." 3 Anderson argues that the ministry is based on something more significant than expediency and that it grows out of and is implied in the great commission according to their gifts. They are sent, commissioned men (Eph 4:11). 4 According to Purkiser, "We are not ordained as

TPurkiser, The New Testament Images of the Ministry, p. 25.

2 Ellen G. White, Spiritual Gifts, 4 vols. (Washington, D.C.: Review and Herald Pub. Assn., 1945), 3:124.

3 Gospel Workers, p. 29.

${ }^{4}$ Martin Anderson, Multiple Ministries: Staffing the Local Church (Minneapolis: Augsburg Publishing House, 1965), pp. 14-15. 
ministers of the church, but as ministers of the gospel in the church." 1 Forsyth says further: "When a man is entrusted with the pastoral care of a Church from its pulpit, he accepts, along with the normality of Scripture, the obligations, limitations, and reserves of the pastoral commission."2

The ministry as a consecration. The word "consecration" is here used in the sense of a person's dedication to the sacred ministry to which God has called him.

Moses defines genuine consecration as obedience to God, to stand in vindication of the right and to show a readiness to carry out the purpose of God in the most unpleasant duties, showing that the claims of God are higher than the claims of friends or the lives of the nearest relatives. The sons of Levi consecrated themselves to God to execute His justice against crime and sin. 3

In this respect White elaborates,

In order for a man to be a successful minister, something more than book knowledge is essential. The laborer for souls needs consecration, integrity, intelligence, industry, energy, tact. 4

The ministry as a challenge. According to white, "The greatest work, the noblest effort, in which man can engage, is to point sinners to the Lamb of God." 5 In Purkiser's words,

There is nothing higher, harder, or holier among men than to minister the unsearchable riches of Christ. No occupation is more elevating, more exacting, more exalted.

The ministry is the only profession among men with eternal consequences. Christ told Peter and his fellow apostles that, in their work of making known what had been bound or loosed in heaven, they would actually be in

${ }^{1}$ Purkiser, The New Testament Images of the Ministry, p. 26.

2p. T. Forsyth, Positive Preaching and the Modern Mind (New York: Hodder \& Stoughton, 1907), p. 101.

3 White, Testimonies, 3:301. 4 White, Gospel Workers, p. 111.

${ }^{5}$ Ibid., p. 18. 
possession of "the keys of the kingdom" (Matt. 16:19).

Beyond measure, indeed, is the challenge of the ministry. $i$

Moses, Joshua, and Caleb accepted God's challenge to conquer Canaan (Num 13-14). "Caleb comprehended the situation, and bold to stand in defense of the word of God, he did all in his power to counteract the evil influence of his unfaithful associates." 2 Elijah challenged the priests of Baal because the Spirit was with him (1 Kgs 17-19). Of Elisha's response to challenge, it is said, "Never had he wavered. Never had he lost his trust in the power of Omnipotence." ${ }^{3}$ White states that every minister should realize the holiness of his work "and show the courage that Elijah showed!" 4 She further said that God uses men who are not afraid "to take a firm stand for the right." 5 "Man can shape circumstances, but circumstances should not be allowed to shape man." 6

The ministry as a continuation of Christ's ministry. "As the Father has sent me, even so I send you" (John 20:21). After almost two thousand years there is danger of forgetting that "the Christian minister is the representative of his Son on earth." 7 Purkiser quotes Bromiley in affirming this:

\section{$27-28$.}

The New Testament Image of the Ministry, pp.

White, Patriarchs and Prophets, p. 388.

3 White, Prophets and Kings, p. 263.

${ }^{4}$ Ibid., p. 142 . ${ }^{5}$ Ibid.

6 Ellen G. White, Ministry of Healing (Mountain View, CA:

Pacific Press Pub. Assn., 1942), p. 500.

7 White, Testimonies, $4: 268$. 
The ministry of the apostles, indeed of all Christian ministers, of all Christians and the whole Christian community, is in the first and last resort the continuing ministry of Jesus.

The human figure is the instrument; Christ himself is the true Minister.1

The ministry involves a summons to reformation. White proposes that continual reform must be kept before the people. ${ }^{2}$ Elijah and Elisha were called "for carrying forward a mighty spiritual reformation" ${ }^{3}$ in their time. Ezra and Nehemiah were called for spiritual revival, which White states "was the beginning of a wonderful reformation." 4 John the Baptist was called to be God's minister in a work of reformation to prepare for Christ's first coming (Luke 1:66-80). He was "to stand as a reformer" in a time characterized by lukewarmness and dissipation. ${ }^{5}$ Since "the testimony to the Laodiceans applies to God's people at the present time, "6 Seventh-day Adventist ministers are called to be reformers, for "ministers who are preaching the present truth should not neglect the solemn message to the Laodiceans." 7

Men of clear understanding are needed now. God calls upon those who are willing to be controlled by the Holy Spirit to lead out in a work of thorough reformation. . . Every soul should now stand in a position of deeper, truer

The New Testament Images of the Ministry, p. 29; in this passage he quotes Geoffrey Bromiley, Christian Ministry (Grand Rapids: Wm. B. Eerdmans, 1959), p. 16.

${ }^{2}$ Ellen G. White, Counsels on Health (Mountain View, CA: Pacific Press Pub. Assn., 1951), p. 445.

${ }^{3}$ White, Prophets and Kings, p. 155. ${ }^{4}$ Ibid., p. 622.

${ }^{5}$ White, Desire of Ages, p. 100.

${ }^{6}$ White, Testimonies, $1: 186 . \quad 7$ Ibid., $3: 257$. 
consecration to God than during the years that have passed.' According to White, reformation "should first begin its purifying work with the ministers." 2 The call is for reformed ministers doing a special work of reformation to prepare for Christ's second coming.

This brief discussion of characterizations of ministry would suggest the seriousness of purpose and commitment with which the minister is to approach his work. Appropriate attitudes in turn must be undergirded by appropriate gifts and talents for ministry, natural or acquired.

Natural Talents

Natural talents, like spiritual gifts, are given by God, affirms McRae. He maintains that these inherited talents should be consecrated to God's glory. ${ }^{3}$ Such natural qualifications as a "good voice and personality" may be indications that help one determine the call to ministry. ${ }^{4}$

It appears desirable that every minister who has natural or cultivated talents such as a pleasant preaching and/or singing voice, special ability to play a musical instrument, or artistic endowments such as drawing, painting, or writing ought to cultivate

$1_{E}$ llen G. White, Testimonies to Ministers (Mountain View, CA: Pacific Press Pub. Assn., 1923), pp. 145-46.

2Testimonies, $1: 469$.

3 William McRae, The Dynamic of Spiritual Gifts (Grand Rapids: Zondervan, 1967), pp. 20-21. 1929, p. 31 .

${ }^{4}$ W. R. French, "The Call to the Ministry," Ministry, August 
them with the view of supplementing his or her ministry. White stresses that the voice and tongue are gifts from God to express melody, love, devotion, and praise to God, ${ }^{1}$ and are a blessing if they are consecrated to the Lord's cause. ${ }^{2}$ The Levites who were assigned "the ministry of song and instrumental music," are cited ${ }^{3}$ as an example. White encourages more interest in voice culture, maintaining that the ability to sing is a talent of influence which God desires all to cultivate. ${ }^{4}$ However, this does not preclude the need for pursuing "knowledge in art, in 1iterature, and in trades. 15

Included in the special gifts God bestows upon some are social and mental abilities. ${ }^{6}$ of the first, which all are urged to cultivate, she says, "By being social and coming close to the people, you may turn the current of their thoughts more readily than by the most able discourse." 7 With respect to the latter: "A11 the powers of the mind should be exercised, all the faculties cultivated, 8 because "the cultivated mind is the measure of the man." One's education should continue throughout his lifetime. 9

\section{$3: 1159$. \\ IEllen G. White Comments--Proverbs, SDA Bible Commentary,}

${ }^{2}$ Evangel ism, p. 498.

${ }^{3}$ Ellen G. White Comments--1 Chronicles 27, SDA Bible Commentary, 3:1128.

4 Evangelism, p. 504.

${ }^{5}$ Ellen G. White, Counsels to Parents and Teachers (Mountain View, CA: Pacific Press Pub. Assn., 1943), p. 19.

${ }^{6}$ White, Gospel Workers, p. 338; Testimonies, 4:619.

${ }^{7}$ Gospel Workers, p. $193 . \quad$ 8estimonies, p. 33.

${ }^{9}$ White, Ministry of Healing, p. 499. 
White devotion and training make a useful worker, the addition of culture makes an outstanding one, according to Anderson. He argues that ministers are responsible for raising their cultural level and stresses reading as a means for accomplishing this. He cites Moses and Paul as examples of "culture at work for God." White also stresses that "it is important for ministers of Christ to see the necessity of self-culture, in order to adorn their profession and maintain a becoming dignity." ${ }^{2}$

In addition to certain natural talents for ministry are the acquired qualifications, or skills, special abilities, and expertise relevant to the accomplishment of the church's mission, qualities which may be acquired by study or professional training.

\section{Acquired Qualifications}

When the Seventh-day Adventist Church was formed a little over a hundred years ago in an America which was essentially rural, ministers needed little academic preparation. However, with today's age of science and technology, of know-how, of expertise, of professionalism and specialization, Adventist ministers must prepare to face the times. ${ }^{3}$ That a minister, therefore must continually update himself in order to be successful in his ministry is obvious.

In today's world every minister needs to acquire some specialized qualifications, i.e., counseling for youth, marriage,

${ }^{1}$ Godfrey T. Anderson, "The Minister and Culture," Ministry, November 1961, pp. 14, 42.

2 Testimonies, $2: 500$.

3 Keld J. Reynolds, "The Ministry in an Era of Expertise," Ministry, December 1967, p. 16. 
the aged, etc. Such on-going training includes the need to attend seminars, workshops, and apprenticeships in different areas of ministry, such as programs of adult education, home study schools, university off-campus courses, as well as the utilization of relevant resources available from different denominations.

Perhaps the most urgent need in the Seventh-day Adventist ministry today is for technicians who are skilled in enabling and involving church members, in accordance with their nature and acquired abilities, to reach out in personal ministry to the "other sheep, that are not of this fold" (John 10:16). Bietz states it wel1: "To find the sheep outside we must have the help of the sheep inside." 1 In this respect Reynolds states:

Providentially, as his [the minister's] audiences and congregation have become better educated and more sophisticated, there have appeared in the ranks of the church an increasing number of physicians, dentists, nutritionists, nurses, and other members of the medical team trained and experienced in public health. There are in the church marriage counselors, psychiatrists, and child psychologists who stand tall in their profession. And there are specialists in the sciences of earth and sky whose scientific vocabulary is without a flaw, yet who view the wonders of creation as befits humble children of God.

Would it not seem better for the pastor and the evangelist as far as possible to take advantage of this wide diversity of knowledge and talent in the congregation by calling on the specialist to contribute his expertise in the service of the church. 2

In short, it appears that high productivity in ministry calls not only for the ability to edify spiritually but also the competency in utilizing the talents of church members in every aspect of the overall mission of the church.

\footnotetext{
1"The Minister's Calling, Work, and Responsibility," p. 12. 2 "The Ministry in an Era of Expertise," p. 17.
} 
Summary

Just as surely as God divinely called the church into existence, so through the ages He has called and enabled men to be ministers in the church. The called-by-God minister constantly manifests growth in all of his inherited and cultivated skills and talents, deriving His sufficiency from the Holy Spirit. As Christ's ambassador, and fully consecrated to the continuation of Christ's ministry through the power of the Holy Spirit, he is committed to lead his flock and others to prepare for Christ's second coming.

The minister strives to perfect every natural and acquired talent and his unique spiritual gifts for excellence in his ministry. This self-culture is an integral part of his personality and involves constant self-updating in order to be more efficient himself and to successfully enable and involve all the natural and acquired qualifications of his church members in the mission of the church as it moves toward the consummation.

One might well conclude that evaluative procedures respecting one's effectiveness in ministry should be significantly influenced by these spiritual aspects of the "call" and the qualifications associated with that call to ministry.. Whether one's call can be adequately judged on the basis of short-term measurabie results is to be questioned. 


\section{CHAPTER IV}

\section{- MINISTERIAL ROLES AS RELATED TO PRODUCTIVITY}

The Bible nowhere lists all the roles and activities of a minister. Nevertheless, using biblical allusions and descriptions, one can form a fairly precise role description for a minister. Blizzard, in his early work ${ }^{7}$ on role conflict, identifies six practitioner roles: preacher, pastor, priest, teacher, organizer, and administrator. The roles of preacher, priest (liturgist), and teacher he characterizes as traditional with clear scriptural basis and religious ideology. The pastoral role he describes as neo-traditional, because although it is supported by a Biblical tradition, it has taken on new direction under the impact of clinical psychology and counseling procedures. Administrator and organizer are seen as contemporary in their orientation in that the ideology of these offices is not so clearly defined in Scripture.

This chapter attempts to build a role description based on $O T$ and NT images of ministerial roles.

\section{Ministerial Roles from OT Images}

Although one must be cautious in drawing firm conclusions for Christian ministry from the OT, certain universal principles

'Samuel W. Blizzard, "The Minister's Dilemma," The Christian Century 73 (1956):508-509. 
seem to be suggested. Calvin, for example, saw the OT images of prophet, priest, and king as applicable in a spiritual sense to the work of a minister. 1

Several images from the 01d and New Testaments are presented for the insights they may offer.

The Priesthood

The Levitical priestly order seems to be the earliest indication of an appointed ministry. For all practical purposes, priests were ministers. Included in their responsibilities was the giving of instruction from the Torah. ${ }^{2}$ They were seen as the bridge between God and His people, 3 offering sacrifices for the sinner, and pronouncing the Lord's blessing and peace upon the people. ${ }^{4}$

The priesthood represented the mediatorial work of Christ. 5 In type, priests represented Christ. "Everything worn by the priest was to be whole and without blemish. By those beautiful official garments was represented the character of. . . Christ. Nothing but perfection, in dress and attitude, in word and spirit, could be acceptable to God." 6

Even though the NT knows nothing of a priestly class of ministers it carries over the special content of the liturgical and

John Calvin, Institutes of the Christian Religion, Trans. John Allen, Book II, Ch. XV (Grand Rapids: Eerdmans, 1949), pp. 540-50.

${ }^{2}$ Purkiser, The New Testament Image of the Ministry, p. 31.

3 Urban Tisner Holmes, The Priest in Community: Exploring the Roots of Ministry (New York: The Seabury Press, 1978), p. 1.

${ }^{4}$ Purkiser, The New Testament Images of the Ministry, p. 31. ${ }^{5}$ White, Desire of Ages, p. $165 . \quad{ }^{6}$ Ibid., p. 709. 
intercessory roles of all who stand for God before the people. Indeed, all Christians are viewed as having a saving, sacramental role, "a royal priesthood . . that you may declare the wonderful deeds of Him who called you. . ." (1 Pet 2:9). Dederen finds in the practice of anointing prophets, priests, and kings in Israel's history the background out of which the NT and present-day rite of ordination arises: ${ }^{1}$ In a sense those who are ordained to the ministry are called to be priests in order that the whole body of believers may be equipped for their "priesthood." ${ }^{2}$ At the same time one may infer that the pastor's. competence in leading congregations into significant experiences of worship and a vivid sense of God's real presence must be taken into account in a normative evaluation of his effectiveness.

The Prophetic Role

The priest and its corresponding prophetic (preacher) roles are of paramount priority among both pastors and laity because people want and need both the ministry of the Word and a sacramental or liturgical ministry. If the minister is effective in the priest and preacher roles, the laity will tend to overlook deficiencies in his other roles. In fact, according to Kadel, "those who make the priest and preacher role the top priority will discover more freedom and sanity in their busy schedules. ${ }^{3}$

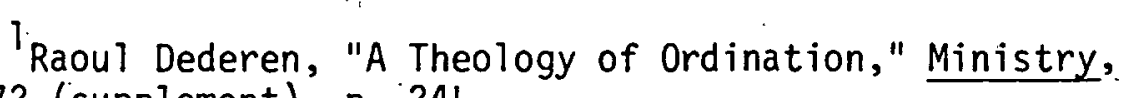
July 1972 (supplement), p. 24L.

2 James Edward Lesslie Newbigin; The Good Samaritan (Grand Rapids: Wm. B. Eerdmans Pub. Co., 1977), p. 43.

3 Thomas E. Kadel, ed., Growth in Ministry (Philadelphia: Fortress Press, 1980), pp. 15-16. 
The prophet was a proclaimer of divine messages, an interpreter of God's oracles. Roeh ("seer," I Sam 9:9) and näbhi ("prophet") both mean one in whom God's message springs forth. In general, the prophet was one upon whom the Spirit of God rested (Num 11:17-29), one to whom and through whom God spoke (Num 12:2; Amos 3:7-8). He delivers divine counsels and foretells God's purposes in the future.' He is "divinely called to instruct the people in the works and ways of God." 2

Like the prophets of old, today's productive ministers proclaim God's word (derivatively) with a view to warning of evil, to correct wrong tendencies, to admonish the people, as well as to lead and encourage. When abuses creep in, the preacher's voice is lifted, calling the people back to sanctification and holiness; he exemplifies the doctrines in his life and teaches them with his lips. ${ }^{3}$ Any discussion of criteria for effectiveness in ministry would certainly include the expressive functions of preaching as embodied in the "prophetic" image.

In OT times prophets were often called men of God, watchmen, or servants of God. These expressions contain further nuances pertinent to ministerial effectiveness.

The prophet as a man of God. The expression "man of God" was applied to Moses (Deut 33:1; Josh 14:6), to Samuel (1 Sam 9:6),

1W. E. Vine, An Expository Dictionary of New Testament Words, 5 vols. (Westwood, NJ: Fleming H. Revell Company, 1952), 3:210-24.

${ }^{2}$ Ellen G. White, Education (Mountain View, CA: Pacific Press Pub. Assn., 1952), p. 46.

3 M. L. Andreasen, The Sanctuary Service (Washington, D.C.: Review and Herald Pub. Assn., 1947), pp. 86-87. 
Shemaiah (1 Kgs 12:22), and Elijah (1 Kgs 17:18, 24). The phrase was synonymous with "true prophet" as contrasted with a false one (1 Kgs $13: 1,6-8,12 ; 17: 24 ; 20: 28 ; 2$ Kgs 1:9). ${ }^{1}$ Prophets were messengers of mercy, ${ }^{2}$ who also were expected to warn and exhort both leaders and people. ${ }^{3}$ According to White, God has His prophets today:

God always has men to whom He intrusts His message. His Spirit moves upon their hearts and constrains them to speak. Stimulated by holy zeal, and with the divine impulse strong upon them, they enter upon the performance of their duty without coldly calculating the consequences of speaking to the people the word which the Lord has given them. 4

The prophet as a watchman. The title of watchman was applied to prophets in the OT (Isa $21: 11$ ). The watchman is to sound the trumpet (Jer $6: 17$ ), to warn of approaching danger (Ezek $3: 17-21 ; 33: 2-6$ ). As watchmen, they "were not to sleep day nor night. They were to discern the enemy, and give the alarm to the people, that everyone might be at his post, that the watching foe might not obtain the least advantage." 5

The prophet as a servant of the Lord. The term "servant of God" was used of such great prophets as Moses (Exod 14:31; Josh 9:24; 1 Chr 6:49), Joshua (Josh 5:14), and Daniel (Dan 6:20). They received the secrets of God for the people (Amos 3:7; Jer 7:25). When Paul called himself the servant of the most high God (Acts 16:17), $34-35$

I Purkiser, The New Testament Image of the Ministry, pp.

${ }^{2}$ White, Patriarchs and Prophets, pp. 382-83. $\quad{ }^{3}$ Ibid.

" "E.1 len G. White Comments" on 1 Pet 2:5, SDA Commentary, p. 1034.

${ }^{5}$ White, Testimonies to Ministers, p. 405. 
or the servant (doulos) of Jesus Christ (Rom 1:1), he was possibly borrowing from the $0 \mathrm{~T}$. In any event, it is obvious that he placed himself in the succession of the prophets. ${ }^{1}$ As such, Paul serves as a link for the NT images of the ministry.

\section{Ministerial Roles from NT Images}

The Minister as a Messenger

The word messenger (aggelos, Mark 1:2) was applied to John the Baptist--"one crying in the wilderness" (Isa 40:3; Matt 3:3; John 1:23). In this capacity he had a direct effect upon the expansional mission of God's movement in his day. The word apostolos is used in like manner, "messengers of the churches" (2 Cor 8:23). Paul called Epaphroditus "your messenger and minister to my need" (Phil 2:25). ${ }^{2}$ Effective pastors minister to the needs of their people. They are messengers who exalt Christ as the sinner's refuge. $^{3}$ The term, of course, would include, as above, the preaching function of the minister. In their preaching the language of the minister must be adapted to the hearers ${ }^{4}$ if they are to be effective messengers for God.

The object of preaching is not alone to convey information, not merely to convince the intellect. The preaching of the word should appeal to the intellect, and should impart knowledge, but it should do more than this. The words of the minister should reach the hearts of the hearers. 5

Sermons are not only to be concerned with relevant content, but the

TPurkiser, The New Testament Image of the Ministry, pp. 35-36.

2 Vine, An Expository Dictionary, 3:64.

3 White, Gospel Workers, p. $158 . \quad 4$ Ibid., p. 169.

${ }^{5}$ White, Testimonies to Ministers, p. 62. 
preacher must mingle "a positiveness with persuasive entreaties" for decision at the proper time.'

The Minister as a "Fisherman"

Christ employed the image of fishermen to the disciples (Mark 1:16-18; Matt 4:18-19; Luke 5:2, 10). Fishermen use nets or fishing rods; the former might represent teamwork evangelism and the latter, personal evangelism. Just as high productivity in fishing by net involves careful study of the tide, weather, and the fish, so successful soul winning depends upon studying the habits of people and adapting techniques and methods to fit their circumstances and needs. Fish that escape the net must be caught individually through hook and bait. Successful soul "fishing" requires several considerations. Truth must be attractively baited in order for a decision to be forthcoming. ${ }^{2}$ Fishermen must fish where the fish are, choose the right time, use tested fishing skills, be persistent, and change lures frequently. ${ }^{3}$ The minister's personal competence as a soul-winner as well as his equipping of church members for both personal and teamwork evangelism or productivity in the expansional mission of the church seems to be the primary suggestion of the "fisherman" image.

The Minister as Shepherd

The word "shepherd" (poimen) literally means one who cares for sheep (Matt 9:36); it is used metaphorically of Christ (Matt

'White, Evangel ism, p. 296.

${ }^{2}$ Roy Allan Anderson, The Shepherd-Evangel ist (Washington, D.C.: Review and Herald Pub. Assn., 1950), pp. 133-35. ${ }^{3}$ Purkiser, The New Testament Images of the Ministry, p. 37. 
26:31; Mark 14:27) and of pastors in the churches (Eph 4:11). ${ }^{1}$ It is the dominant image of the minister as a pastor, serving as spiritual counselor and comforter, whose ears are trained to hear the cries and needs of his members of all ages, dealing "gently with the ignorant and wayward" (Heb 5:2). Such a ministry contrasts with that of the hireling, who is concerned only with doing a job for pay (Ezek 34:2, 6; John 10:11-14). The shepherd-pastor endeavors to prevent losses, yet spends time seeking for backsliders in an effort to rescue the wandering sheep. He combines the role of guiding the flock with caring for individual sheep. He knows his "flock" and prays for his people, studying with them and frequently counselling them as part of his shepherding. Like Christ, the Good Shepherd, the undershepherds are not only willing to live for their sheep, but to "die" for them. ${ }^{2}$ A minister's competence in pastoral care is, of course, a key criterion in evaluating effectiveness.

The Minister as a

Fellow-Laborer

Sunergos is translated as "fellow-laborer," "fellowworker" (1 Cor 3:9; Phil 2:25). One may be "God's fellow worker" (1 Cor 3:9) or a "fellow worker in the truth" (3 John 8). This image points to the minister's role as promoter of fellowship, ${ }^{3}$ or participation and partnership. ${ }^{4}$ "God has bound us

'Vine, An Expository Dictionary, 4:19.

2 Anderson, The Shepherd-Evangel ist, pp. 551-66.

3 Vine, An Expository Dictionary, 2:304.

${ }^{4}$ White, Gospel Workers, p. 392. 
together as members of one family, and this relationship everyone is bound to cherish." 1 Workers are enlisted in Christ's army to be united in sentiment, action, spirit, and fellowship against the enemy. They will act in Christian fellowship and harmony, wearing the badge of Christ. ${ }^{2}$ The productive minister, in partnership with Christ, fosters unanimity of purpose and harmony of action for the overall growth of the church. This includes peer relationships as well as relationships with all fellow Christians.

The Minister as a Steward

The word "steward" (oikonomos) primarily denotes the manager of a household or estate (Luke $12: 42 ; 16: 1,3,8 ; 1$ Cor $4: 2$, Gal $4: 2$, or "treasurer of a city (Rom $16: 23, \mathrm{RV}$ ). ${ }^{3}$ This could include the ministerial role of leadership and administration of the church or "House" of God. In Gal 4:2 oikonomos is translated as "trustee" and used as a synonym of epitropos, translated as "guardian." This same word is rendered "steward" in Matt 20:8 and Luke 8:3. An allied noun, epitrope, is translated "commission" in Acts 26:12 and refers to delegated authority over people, ${ }^{4}$ which is fundamental in the leadershipadministrative role of ministry. The parable of the dishonest steward (Luke 16:1-14) teaches that the minister/steward must have prudence and wisdom in handling his master's affairs and give strict account of his administration. He must have discernment and be able to act instantly

'White, Testimonies, $4: 399$.

2 White, Gospel Workers, p: 392.

3 Vine, An Expository Dictionary, 4:74.

${ }^{4}$ Ibid., 2:183. 
when the occasion calls for it, for victories may be lost through delay. ' Efficiency requires the delegating of responsibility and authority for the various departments of the church. ${ }^{2}$ The believers are to be united in an organized and wel1-directed effort to present Christ to the entire world under the direction of the Holy Spirit. ${ }^{3}$ Thus to carry forward the church's mission is the ultimate goal of the productive SDA minister as a leader/administrator steward.

Part of the minister/steward role is to serve as a link between the local church and the local conference, from which he receives his credentials, to which he looks for orientation and counsel, and to which he must render account. ${ }^{4}$ Thoughtful writers today see the administrative role as an integrating master role under which all the minister's responsibilities may be subsumed. ${ }^{5}$

The Minister as an Ambassador

To be an ambassador (presbeuō, 2 Cor 5:20; Eph 6:20) in Biblical usage involved the experience suggested by the word "elder." ${ }^{6}$ The term describes the function of those who beseech men "in Christ's stead" to be "reconciled to God." The word connotes

TWite, Gospel Workers, pp. 133-34.

${ }^{2}$ Ibid., pp. 197-98. 3 Ibid., p. 444.

${ }^{4}$ Ibid., p. 418.

${ }^{5}$ Alvin J. Lindgren, Foundations for Purposeful Church Administration (Nashville: Abingdon Press, 1965), p. 16; Donald P. Smith, Clergy in the Crossfire (Philadelphia: The Westminster Press, 1973), p. 99.

${ }^{6}$ Vine, An Expository Dictionary, 1:53. 
authority and dignity ${ }^{1}$ which are acquired by mature Christian experience. Paul, in prison, called himself "an ambassador in bonds" (Eph 6:20). Christ's name was for the disciples the authority for their actions and the Source of their success. ${ }^{2}$

Ministers are more than mere public speakers. As Christ's ambassadors they stand in Christ's stead; therefore the Savior's voice ought to be heard through them. ${ }^{3}$

The Minister as a Husbandman

A husbandman (geōrgos, 2 Tim 2:6; James $5: 7$ ) is a tiller of the ground (Matt 21:33-35, 38, 40, 41; see also Mark 12, Luke 20), a vine-dresser. In John 15:1 Christ introduces the Father as the Husbandman, Himself as the Vine, and His disciples as branches. The husbandman keeps foremost in his mind that the objective of his labor is the harvest, the production of "much fruit." 4 The role of husbandman naturally includes the responsibility of sowing seed everywhere--"along the path," on "rocky ground," "upon thorns," and, of course, "on good soil" (Matt 13:3-8). He realizes that time and productivity vary. In one case the yield may be "a hundredfold, in another sixty, and in another thirty" (vs. 23). There is seen here the need to present the gospel to all classes of people. "In all the highways of life there are souls to be saved. . . . Give them

\footnotetext{
1 Purkiser, The New Testament Images of the Ministry, p. 41. 2 White, Acts of the Apostles, p. 28.

${ }^{3}$ White, Testimonies, 4:393-95.

${ }^{4}$ Vine, An Expository Dictionary, 2:241.
} 
the light, and God will bless you, as His laborers." 1 In the ministry as well as in agriculture, high productivity is the fruit of both efficient personal efforts and coordinated teamwork. Paul planted, Apollos watered, but God, who gave the growth, deserves the glory, and He in turn rewards each participant according to his labor (1 Cor 3:6-9).

The Minister as a Model

The minister's role as a model (tupos, Titus $2: 7$ ) and example (hupotupōsis, $1 \operatorname{Tim} 1: 16)^{2}$ is, perhaps, the most challenging of all roles. In fact, it intermeshes with all the others. Christ the supreme Model, was an example to all who believed in Him. The ambassadors of Christ are enjoined to be "in all respects a model of good deeds" (Titus 2:7). Paul forthrightly acknowledges that he purposefully conducted himself in such a way that he would be an example for others. "Be imitators of me, as I am of Christ" (1 Cor 11:1). In this White concurs: "Our example will preach louder than words," 3 for "a godly example will tell more for the truth than the greatest eloquence, unaccompanied by a well-ordered 1ife." 4 In short, proficient ministers are to hide themselves in the supreme Model, become a pattern worthy of imitation, "in speech and conduct, in love, in faith, in purity" (1 Tim 4:12), well able to fight in the Lord's army as exemplary soldiers of the Master.

White, Evangelism, p. 553.

${ }^{2}$ Purkiser, The New Testament Images of the Ministry, p. 43.

3 White, Counsels on Stewardship, p. 41.

${ }^{4}$ White, Gospel Workers, p. 104. 
Summary

Effective ministers represent the holy dignity of Christ's mediatorial work, incorporating all of their members into the priesthood of believers. In their prophetic role they instruct the people, presenting messages of mercy and warning and lifting up the voice to bring people back to sanctification and holiness when this is needed. A minister serves the Lord by feeding, counseling, nurturing, and healing the sheep. He combines effectiveness in the expressive functions of preaching and teaching, with the instrumental functions of pastoral care and oversight.

A minister's work is characterized by Christian fellowship, in which a spirit of partnership unites the members in sentiment and action toward the fulfillment of the mission of the church. He organizes well-directed efforts to this end, delegating responsibility and authority. His Christian character epitomizes Christ's love toward his church members as he seeks to nurture them toward maturity and to unite their human efforts with divine power.

Chapters 2 through 4 explored the nature of ministry and the qualifications for ministerial effectiveness. The basic source was the Bible, although other writers and especially Ellen G. White were consulted. Much that emerged was in the form of allusions--the "husbandman," the "shepherd." In the synthesis that follows an attempt has been made to state in current terminology what appear to be the most important qualifications for an effective minister.

1. The minister must be a godly person, committed to ministry, to God and to the church. 
2. The minister must use well his talents and gifts, both the natural and the acquired, intellectual, physical, social, and spirituat.

3. A minister should be a leader--an example, a motivator, an enabler.

4. A minister should be a steward--responsible and accountable to God, to the church leadership and members of the time, finances, and people entrusted to him.

5. A minister should be a communicator--a proclaimer of God's word and well capable of facilitating interpersonal communications and relations.

6. A minister must be a nurturer--one whose activities foster personal and spiritual growth within the members, among the members, and outside the circle of the members.

7. A minister must be a teacher--one who knows many answers, who knows where to find more answers, but above all else knows how to transmit this knowledge to others.

Chapter 5 describes the responses of church administrators in the South American Division to a questionnaire designed to elicit information regarding their understanding of the relative importance of different aspects of ministerial effectiveness. The responses of these administrators will then be compared to the criteria summarized from the study of the Bible and the writings of Ellen G. White. 
PART I I

PERSPECTIVES ON MINISTERIAL EFFECTIVENESS

IN THE SOUTH-AMERICAN DIVISION OF SEVENTH-DAY ADVENTISTS 
CHAPTER $V$

\section{SOME CURRENT UNDERSTANDINGS OF MINISTERIAL \\ EFFECTIVENESS IN THE SOUTH-AMERICAN \\ DIVISION}

This chapter attempts to explore current understandings of ministerial effectiveness or productivity in the South American Division ( $S A D)$. The first part describes the results of a survey of mission, conference, and union administrators of the SAD. The second part considers three different types of information regarding perceptions of ministerial effectiveness: (1) evaluation questionnaires used in three unions, (2) interviews with SAD workers now pursuing doctoral programs at Andrews University, and (3) case studies derived from the experiences of two ministers in Brazil.

Survey of Mission, Conference, and Union Presidents

Thirty-nine questionnaires were sent to mission, conference, and union presidents of the SAD. Of these, 32 were returned in usable form, giving an 82 percent response. Most of the questionnaires were completed by the presidents themselves, although some were completed by the conference executive secretary or ministerial secretary; one conference president studied it with the conference committee so that the answers represented administrative consensus in that field.

The questionnaire was composed of two sections. The first section was designed to elicit opinions regarding factors these 
administrators might regard as influential in determining pastoral productivity. These were grouped into five main areas: personal factors, leadership and administrative factors, pastoral factors, preaching/evangelistic factors, and statistical measurements. A second section was comprised of open-ended questions asking for definitions, opinions-and suggestions regarding productivity.

The second section is considered first in that it provides a more immediate and concrete picture of how church administrators in the SAD might proceed in the evaluation of effectiveness in ministry.

Open-ended Questions

The data from section $F$ of the questionnaire, with the exception of questions 2 and 4, sought for definitions, opinions, and suggestions. These are considered point by point.

Question 1. How would you define the concept of a "productive" minister?

In their replies the respondents enumerated several activities, qualities, abilities, and attitudes included in the concept of productivity. Most of them are repetitive or very similar in meaning; therefore these are stated in nine groups of responses as follows:

Eight respondents mentioned that a productive minister motivates, equips, and enables the laity for service, organizes the work with them, and is able to integrate the majority of the membership into the overall mission of the church.

Eight respondents indicated that the productive minister is a good leader and administrator who, through committees, plans the 
work of the church and the setting of goals, delegates responsibilities and authority, and then evaluates the resulting performance.

Seven respondents replied that the productive minister is consecrated, has a deep Christian experience, and looks at life from a holistic viewpoint.

According to six respondents, the productive minister has a sense of vocation applying his personal talents properly as well as making full use of the talents of the membership. (No respondent mentioned spiritual gifts.)

Six respondents mentioned that the productive minister is one who nurtures his flock well and the resultant high spiritual quality may be clearly perceived in strong faith, sound doctrines, and stability in the church.

The productive minister, according to six respondents, develops every aspect of the ministry and reaches all the goals of the church, with uniform growth taking place in all of its departments.

Five respondents indicated that a productive minister is firm and loyal with respect to the foundation principles of the church and to the programs of the conference.

Three respondents felt that a productive minister is a good preacher and evangelist.

According to three respondents, the productive minister is one who through various ways and means baptizes many individuals. Only one respondent attempted to define a productive minister, and he framed his definition in the following concise terms: "The productive minister is one who satisfies the internal 
and external purpose[s] of the church."

It would appear from the range of replies that the question was too open-ended. More precise guidance here might have elicited responses more focused for our purposes. Nevertheless, a majority of the responses appear to be supportive of those emphases which emerged in our examination above of ministerial productivity from a scriptural perspective, particularly those emphases that dealt with role functions. Productive ministers, according to at least a third of the respondents, do certain things: they motivate and equip the laity for ministry; organize and coordinate lay activities; provide oversight in the programatic components of church life; perform administrative functions such as delegating authority and requiring accountability; provide Christian nurture, presumably through preaching, pastoral care, and worship; and perform evangelistic activities.

A smaller group of respondents replied in terms of the kind of person a productive minister would be: one with a sense of vocation; a devout and committed Christian; one who is loyal to the teachings and the programs of the denomination.

An even smaller group responded in very general terms describing the ultimate outcomes of a productive ministry; balanced church growth, evangelistic results, and achievements of denominational goals.

Question 2. How important do you regard qualitative achievements in evaluating the minister's productivity? (e.g., spiritual condition of the congregation?) 
Seventy-one percent of the respondents felt the inclusion of qualitative achievements in the evaluation of the productivity of ministers was very important; 19.4 percent said it to be absolutely essential; 6.5 percent considered it to be somewhat important; and 3.2 percent felt it was unimportant. These responses would appear to contradict those who claim that denominational leaders as a rule are only concerned with quantitative results. Some might suggest that since qualitative achievements are very difficult to measure, wherever evaluation of ministers occurs by denominational leaders, the perception is that numbers alone count, since such statistics are more readily accessible for measurement.

Question 3. In your opinion, who should establish the church goals?

According to the replies given to this question, 87.5 percent of the respondents felt that the local churches and/or groups should establish their own goals; 9.4 percent thought that the president should establish them; only 3.1 percent advocated that this was an administrative responsibility. This seems to point to considerable concession toward a democratic style of leadership as opposed to frequently expressed views that goais and programs are imposed, upon churches "from the top." 1

Question 3 also provided space for the respondents to make comments on the choice they made. Two respondents did not fill in this section of the question, eleven gave only one reason for their answer, while nineteen listed from two to five different reasons for

${ }^{7}$ The validity of such perceptions would have to be another study in the light of the responses given here. 
their responses. Of the respondents who felt that the local churches and groups should establish their own goals, the following reasons were listed:

Eight believed that this would help the local churches to develop a greater sense of responsibility for their goals and at the same time would foster the development of the spiritual gifts and talents of members to full potentiality.

Seven pointed out that in order to set realistic goals, the churches would need pastoral and administrative orientation.

Seven believed that the local churches best knew and understood the circumstances and possibilities of their own area and could better relate to goals which they themselves had set.

Six felt that in setting their own goals the local churches would be more self-motivated, more conscientious in fulfilling the goals, and more enthusiastic, due to the goal-setting experience.

Five thought that choosing their own goals would avoid the feeling of imposition.

Two mentioned that setting their own goals would engender greater involvement on the part of the church membership.

One respondent felt that the local churches would be inclined to set higher goals for themselves than the administration would.

Another felt that in the local church that sets its own goals, the pastor had more freedom to hold the members accountable for those goals.

Still another respondent indicated that the local church which sets its own goals is better able to solve its own problems and may possibly work more closely with their minister. 
of the three respondents who thought that the president should be the one to establish church goals, one said that since the president had access to statistical data, he could better evaluate all possibilities; the second believed that the president, in counsel with the ministerial secretary, knew the growth potential of each district; the third gave no reason for his choice. One respondent also noted that the goals could well be set in a district meeting with the participation of the administration.

The single respondent who advocated that the local pastor ought to establish the goals of the church reasoned that the pastor best knew his own congregation.

Question 4. Approximately how long should be the term of a pastor in one church/district?

Table 1 presents the data that resulted from the answers to this question. Fourteen respondents, or 45.2 percent, thought that pastors should remain in a church for about five years; eleven, or 35.5 percent, felt that four-year terms were ideal; four, or 12.9 percent, thought that six years was the best length of a pastoral term; only two, or 6.5 percent, thought that a three-year term was adequate. These data clearly indicate that the preponderance of the respondents ( 80.7 percent) felt that a term of approximately four to five years was most desirable for optimal ministerial productivity. ${ }^{1}$ Thus the responses of the administrators point in the direction of longer terms.

lPersonal observations would lead me to believe that in practice, the average tenure is much shorter, but this expression of the value of longer terms is encouraging, in my opinion. 
TABLE 1

RESPONSES OF THE ADMINISTRATORS TO THE QUESTION

PERTAINING TO THE LENGTH OF THE PASTORAL TERM

\begin{tabular}{ccc}
\hline $\begin{array}{c}\text { Number of } \\
\text { Respondents }\end{array}$ & Percent & $\begin{array}{c}\text { Number of } \\
\text { Years }\end{array}$ \\
\hline 14 & 45.2 & 5 \\
11 & 35.5 & 4 \\
4 & 12.9 & 6 \\
2 & 6.5 & 3 \\
\hline
\end{tabular}

Question 5. Please comment on the following statement:

"A minister should be evaluated on his total experience in ministry in a given church/district rather than on the basis of a single good or poor year's work (or results)."

Twenty-one of the respondents answered this question with only a "yes" or a few short words of agreement. The responses of the eleven who commented in greater length are summarized below in eight categories:

Five respondents felt that a longer period of time is necessary in order to develop the several areas of ministry that may produce harmonious and symmetrical church growth.

Three of the respondents mentioned that it requires time to implement an effective overall program.

Three respondents pointed out that there are variations of circumstances with the passing of years that may affect the productivity of a particular year.

Two respondents noted that productivity (as well as 
deficiencies) can be more evident in a five-year span of time.

Two respondents thought it would be wise to have a permanent evaluation record with a partial update of the evaluation done yearly that might serve in presenting an average picture of the minister's productivity by the end of his pastoral term.

One respondent felt evaluation of the ministry for the total pastoral term was the only way to have an impartial and just evaluation without distortion.

Another respondent pointed out that churches and districts have different indices of possibilities and difficulties that must be considered in the evaluation even in longer pastoral periods.

Another respondent observed that it can be counter-productive to make comparisons among ministers working in different circumstances with different indices of productvity.

The consensus seemed to reflect the belief that longer pastoral terms may provide a better overall picture of a pastor's productivity as well as lead to more satisfying results in the process of evaluating ministers.

Question 6. Would you see merit in providing a system of evaluation of pastors, including officers and members of the church in this process? Please comment on your answer.

The respondents were asked to respond "Yes" or "No" to the first question and to use the space provided for further comments on the answer they gave. Four respondents (12 percent) did not answer the Yes-or-No question. Of the twenty-eight who did, eighteen or 64.3 percent, checked "Yes," while ten, or 35.7 percent, checked "No." It appears that in general the respondents felt that it was 
very important to provide a system of evaluation for pastors which included officers and members of the church.

The respondents who gave a "Yes" answer listed the following reasons for their choice:

Eight felt that church members know aspects of the pastor's work that might be ignored by administrators, and because of this they are better qualified to contribute to their pastor's evaluation.

Six respondents noted that the church members continually evaluate their minister, and that with care to avoid exposing him to criticism, an objective and well-oriented evaluation could be accompl ished.

Six respondents observed that since the minister is the servant of the church, the church has the authority and the privilege to give an accurate opinion. Membership opinion is more important than suspected according to these respondents, who noted that the opinions of responsible church members would tend to be more objective than those of the administration.

According to five respondents, the evaluation must be done in the form of support and feedback from those who work closest to the minister, who help him, who suffer with him. This group felt that only church officers should be involved in such an evaluation.

Two respondents felt that only by involving the totality of church members could an honest, just, and objective evaluation of the minister be performed.

One respondent thought that such an evaluation might well be initiated by the minister himself rather than by the administration.

The respondents who gave a "No" answer, listed the following reasons for this choice: 
Six respondents felt that the evaluation of ministers is the responsibility of the conference administrative board, to which perhaps some church officials could be invited to contribute.

Three respondents pointed out that evaluation which included church officers and/or members would signify giving the laity power over the minister, providing occasion for them to judge subjectively rather than objectively. It was noted that the church manual establishes that the minister is accountable to the mission/conference administration and not to the church or the district.

Three of the respondents were concerned that the opinions of church members might result in ugly consequences and might open the door for unnecessary confrontations because there are always unsympathetic brethren in every church.

Three respondents fear that in some places the evaluation criteria might be affected by emotions, groups interests, authoritarian church officials who might manipulate the procedure to make the minister vulnerable.

One respondent admitted that such an evaluation might turn out to be practical, but perhaps not just, because the pastor's deficiencies might be dissected by the members and the pastor might be humiliated as a result.

Another respondent observed that while some churches would help the minister, others might harm him.

Another respondent felt that if such an evaluation were to be made, the church must be very mature.

One respondent mentioned that the minister is called by God and therefore only those called by God are in a condition to evaluate 
him. He noted that in the apostolic church this was the task of the apostles and the Holy Spirit.

From the variety of responses, suggestions, and expressed concerns, it is obvious that further. study needs to be given to this area. While there appear to be many who are ready to involve the laity in an evaluation process of the pastor, a significant number hold reservations and offer thoughtful reasons for concern.

Question 7. Please offer any other suggestion or observation that might contribute to the process of evaluating the success, results, or productivity of pastors.

Ten respondents did not respond to this final item on the questionnaire. Twenty-one of the opinions and suggestions pertained to items not already covered. Some respondents offered more than one observation. The answers are presented according to content:

Five respondents mentioned that the following items were very important qualities that ought to be considered in the evaluation of a minister: personal and family qualities (such as tact, capacity for positive relationships, pleasure and satisfaction derived from and by his family), his personal appearance, self-improvement, balance in personal finances, and the extent of his influence.

Four respondents pointed out that such an evaluation should be based on the sowing, reaping, and conservation of members rather than on the number of baptisms alone. Losses for apostasy should be included. Tithes, offerings, and general finances, as well as other statistical measurements, should be part of the evaluation.

Four respondents observed that the leadership capacity of the 
minister can be improved by ranking church priorities, by never losing sight of the fundamental objectives of preaching and soul winning without neglecting other legitimate ministerial tasks, such as punctuality in mailing reports to the conference or promoting the programs that have to be performed for the most part by we11equipped laity.

Two respondents suggested that the spiritual vitality of the consecration of the church and the quality of new converts should be considered in any pastoral evaluation.

Two respondents felt that the administration should be completely acquainted with the working circumstances of each minister. It was their opinion that a minister should never be evaluated by a single individual, whether that person be the president, ministerial secretary, or some other individual.

One respondent suggested that before planning any pastoral evaluations, the administration should provide a definite job description for ministers which would clearly outline what was required of him, list objectives, and spell out priorities. This job description should be given to every minister.

Another respondent noted that the confidence and status of a minister must be lifted higher than that of the departmental director-at the president's level.

Another respondent emphasized that the process of evaluation should be known and understood by each prospective minister from the first year of his/her theological studies.

Another respondent felt that especially during the first two years of ministry, the minister should be supported and helped 
a great deal, while at the same time being evaluated. He contended that the conference leadership should invest much time in the orientation process of all new ministers and should maintain a follow-up system for educating younger ministers toward a productive ministry.

From the above suggestions, observations, and warnings given by the respondents, both leaders and ministers may obtain valuable insights toward more accurate development of their system of evaluation.

\section{The Objective Questionnaire}

The respondents were asked to evaluate on the objective part of the questionnaire each of the fifty-five factors. This was to be done on a decreasing scale of one to four, with one representing unimportant; two, somewhat important; three, very important; and four, absolutely essential. The median scores of the four choices were categorized according to the following:

$$
\begin{aligned}
1-1.49 & =\text { unimportant } \\
1.50-2.49 & =\text { somewhat important } \\
2.50-3.49 & =\text { very important } \\
3.50-4.00 & =\text { absolutely essential }
\end{aligned}
$$

For the sake of clarity and convenience in analyzing the data, the results were tabulated according to absolute frequency (number), relative frequency (percent), and median score.

The respondents of the thirty-two returned questionnaires were analyzed section by section in their ranked order. The main inter-correlations between various factors were then analyzed and 
listed in the order of priority according to median scores.

Personal factors. Table 2 presents the data for section A of the questionnaire, "Personal factors influential in determining pastoral production." The evaluation of the respondents for the seventeen factors in this section are listed in order of perceived priority according to the median score of each factor. In this section the factor, "Maintaining a meaningful devotional life," received the highest median score (3.96), with "Having a sense of calling to ministry" following close on its heels (3.94 median score). These two factors may possibly be interrelated because cultivating the devotional life is perceived as essential in maintaining a daily infilling of the Holy Spirit, which, in turn, would enhance one's sense of the divine call.

Third in order of importance was. "A happy marriage" (3.90 median score). It is obvious that the minister's personal wel1being is seen to be a crucial element in his professional life. "Organizing work according to priorities," with a median score of 3.70, seems to be inter-related with factor 71 , "Being efficient in personal time management" (3.38 median score). Both should contribute to greater productivity. "Making proper personal appropriation of the Biblical message," with a median score of 3.65, and "Making proper personal appropriation of Ellen G. White's messages ( 3.50 median score) seem to be related. Both of these factors should, in the view of Seventh-day Adventists, tend to strengthen the devotional life, which in turn should lead the minister to greater efficiency in guiding corporate worship, which 
TABLE 2

EVALUATION OF THE CRITERIA THAT GOVERN THE CONCEPT OF MINISTERIAL PRODUCTIVITY IN ADVENTIST MINISTERIAL FUNCTIONS. ACCORDING TO SELECTED SAD UNION, CONFERENCE, AND

MISSION ADMINISTRATORS: PERSONAL FACTORS

\begin{tabular}{|c|c|c|c|c|c|c|c|c|c|}
\hline \multirow{2}{*}{\multicolumn{2}{|c|}{$\begin{array}{l}\text { Questionnaire } \\
\text { Item } \\
\text { No. }\end{array}$}} & \multicolumn{2}{|c|}{$\begin{array}{l}\text { Absolutely } \\
\text { Important }\end{array}$} & \multicolumn{2}{|c|}{$\begin{array}{l}\text { Very } \\
\text { Important }\end{array}$} & \multicolumn{2}{|c|}{$\begin{array}{l}\text { Somewhat } \\
\text { Important }\end{array}$} & $\begin{array}{l}\text { Unim- } \\
\text { portant }\end{array}$ & \multirow{2}{*}{$\begin{array}{l}\text { Median } \\
\text { Score }\end{array}$} \\
\hline & & No. & $\%$ & No. & $\%$ & No. & $\%$ & No. $\%$ & \\
\hline 7 & $\begin{array}{l}\text { Maintaining a meaningful devotional } \\
\text { life }\end{array}$ & 30 & 93.8 & 2 & 6.2 & & - & - & 3.96 \\
\hline 1 & $\begin{array}{l}\text { Having a sense of calling to the } \\
\text { ministry }\end{array}$ & 29 & 90.6 & 3 & 9.4 & & - & - & 3.94 \\
\hline 8 & Having a solid and happy marriage & 27 & 84.4 & 5 & 15.6 & & - & - & 3.90 \\
\hline 10 & $\begin{array}{l}\text { Organizing work according to } \\
\text { priorities }\end{array}$ & 20 & 62.5 & 12 & 37.5 & & - & - & 3.70 \\
\hline 14 & $\begin{array}{l}\text { Making proper personal appropriation } \\
\text { of the Bible }\end{array}$ & 19 & 59.4 & 9 & 28.1 & 4 & 12.5 & - & 3.65 \\
\hline 6 & $\begin{array}{l}\text { Maintaining a balanced program of } \\
\text { work, rest, and recreation }\end{array}$ & 17 & 53.1 & 14 & 43.8 & 1 & 3.1 & - & 3.55 \\
\hline 13 & $\begin{array}{l}\text { Percciving one's weaknesses and } \\
\text { learning how to overcome them }\end{array}$ & 17 & 53.1 & 14 & 43.8 & 1 & 3.1 & - & 3.55 \\
\hline 3 & Enjoying good health & 16 & 50.0 & 14 & 43.8 & 2 & 6.2 & - & 3.50 \\
\hline 15 & $\begin{array}{l}\text { Making proper personal appropri- } \\
\text { ation of Ellen G. White's }\end{array}$ & & & & & & & & \\
\hline & messages & 16 & 50.00 & 13 & 40.6 & 3 & 9.4 & - & 3.50 \\
\hline
\end{tabular}


TABLE 2--Continued

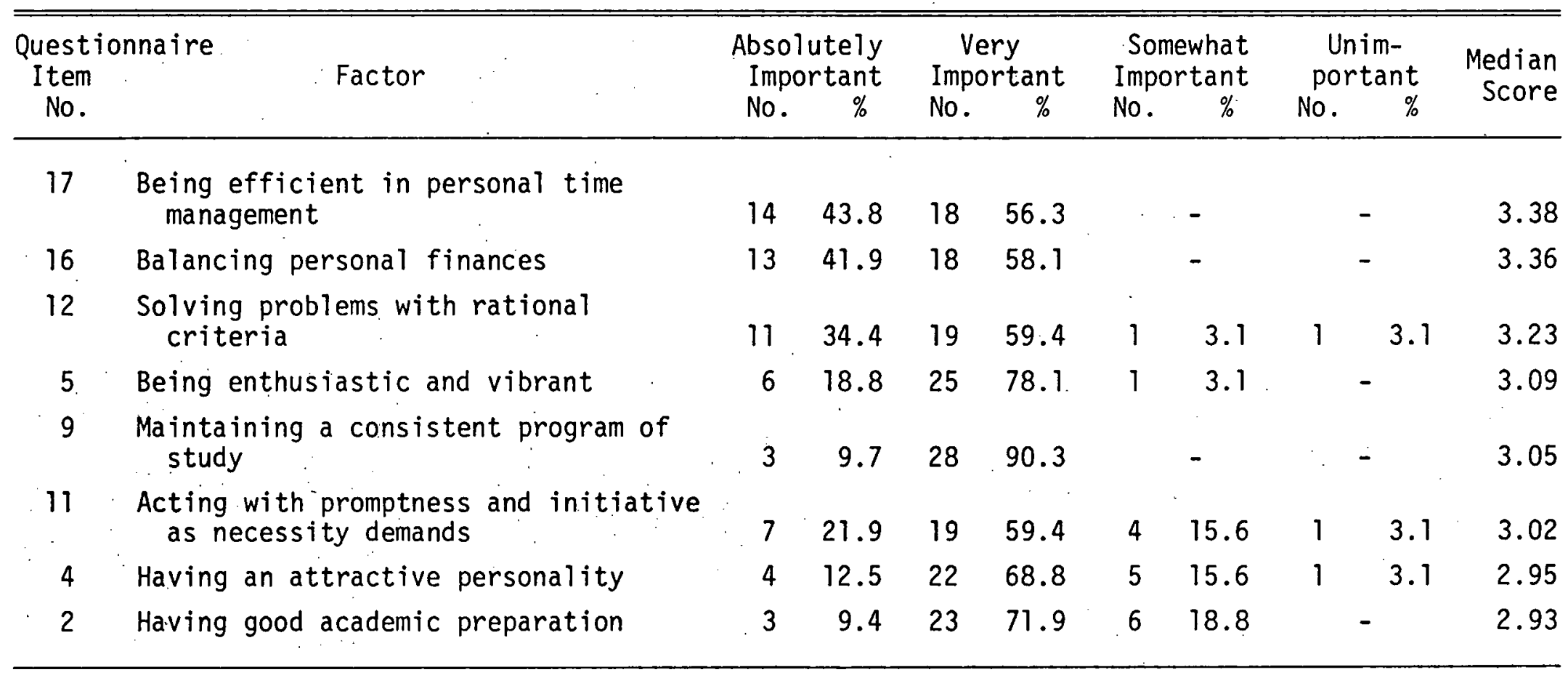


is central to the vital mission of the church. "Maintaining a balanced program of work, rest, and recreation" and "Perceiving one's weaknesses and learning how to overcome them" received identical median scores of 3.55. These two factors complement each other for perfecting work performance and may also contribute to the factor of "Enjoying good health" (3.50 median score).

The remaining factors also merit attention inasmuch as their relatively high ratings are viewed as significant for productivity. It is evident that the factor with the lowest mean score (2.93), "Having good academic preparation," while it still falls into the very-important category, is seen as less important by these respondents than the religious factors.

Leadership and administrative factors. The data in table 3 represent section B of the questionniare, "Factors of leadership and administration influential in determining pastoral productivity." The first four factors as ranked by the respondents reflect a generaliy accepted chain of priorities for pastoral effectiveness: "Preparing and conducting practical training courses for winning and establishing new members" ( 3.70 median score), "Instructing church officials and laity in principles of Christian leadership" (3.55 median score), "Planning and implementing long, medium, and short-term church district programs" (3.50 median score), and "Delegating responsibilities and authority to the leaders and members of the [local] church" (3.50 median score). The expansional mission of the church is achieved in direct proportion to these factors. This is strongly 
TABLE 3

EVALUATION OF THE CRITERIA THAT GOVERN THE CONCEPT OF MINISTERIAL PRODUCTIVITY IN ADVENTIST

MINISTERIAL FUNCTIONS ACCORDING TO SELECTED SAD UNION, CONFERENCE, AND MISSION ADMINISTRATORS: LEADERSHIP AND ADMINISTRATIVE FACTORS

\begin{tabular}{|c|c|c|c|c|c|c|}
\hline $\begin{array}{l}\text { Questionnaire } \\
\text { Item }\end{array}$ & Factor & $\begin{array}{l}\text { Absolutely } \\
\text { Important }\end{array}$ & $\begin{array}{c}\text { Very } \\
\text { Important }\end{array}$ & $\begin{array}{l}\text { Somewhat } \\
\text { Important }\end{array}$ & $\begin{array}{l}\text { Unim- } \\
\text { portant }\end{array}$ & $\begin{array}{l}\text { Median } \\
\text { Score }\end{array}$ \\
\hline No. & & No. $\quad \%$ & No. $\%$ & No. $\%$ & No. $\%$ & \\
\hline
\end{tabular}

6. Preparing and conducting practical training courses for winning and establishing new members

Instructing church officials and laity in principles of Christian leadership

$\begin{array}{llllllll}20 & 62.5 & 11 & 34.4 & 1 & 3.1 & - & 3.70 \\ 17 & 53.1 & 15 & 46.9 & - & - & 3.55 \\ 16 & 50.0 & 16 & 50.0 & - & - & 3.50 \\ 16 & 50.0 & 16 & 50.0 & - & - & 3.50 \\ 15 & 46.9 & 17 & 53.1 & & - & - & 3.44 \\ 12 & 37.5 & 18 & 56.3 & 2 & 6.2 & - & 3.27\end{array}$


TABLE 3--Continued

\begin{tabular}{|c|c|c|c|c|c|c|c|c|c|c|}
\hline \multirow{2}{*}{\multicolumn{2}{|c|}{$\begin{array}{l}\text { Questionnaire } \\
\text { Item } \\
\text { No. }\end{array}$}} & \multicolumn{2}{|c|}{$\begin{array}{l}\text { Absolutely } \\
\text { Important }\end{array}$} & \multicolumn{2}{|c|}{$\begin{array}{l}\text { Very } \\
\text { Important }\end{array}$} & \multicolumn{2}{|c|}{$\begin{array}{l}\text { Somewhat } \\
\text { Important }\end{array}$} & \multicolumn{2}{|c|}{$\begin{array}{l}\text { Unim- } \\
\text { portant }\end{array}$} & \multirow{2}{*}{$\begin{array}{r}\text { Median } \\
\text { Score }\end{array}$} \\
\hline & & No. & $\%$ & No. & $\%$ & No. & $\%$ & No. & $\%$ & \\
\hline 2 & $\begin{array}{l}\text { Promoting and synchronizing } \\
\text { activities of all divisions } \\
\text { of the [local] church }\end{array}$ & 11 & 34.4 & 21 & 65.1 & & - & & - & 3.26 \\
\hline 9 & $\begin{array}{l}\text { Being responsive to the suggestions } \\
\text { of church officers and members }\end{array}$ & 3 & 9.4 & 28 & 87.5 & 1 & 3.1 & & - & 3.03 \\
\hline 5 & $\begin{array}{l}\text { Proficiency in organizing and } \\
\text { directing church business } \\
\text { sessions }\end{array}$ & 4 & 21.9 & 19 & 59.4 & 5 & 15.6 & 1 & 3.1 & 3.02 \\
\hline 11 & $\begin{array}{l}\text { Perceiving and relating sensitively } \\
\text { to cultural and sociological } \\
\text { differences in people }\end{array}$ & 7 & 21.9 & 17 & 53.1 & 7 & 21.9 & 1 & 3.1 & 2.97 \\
\hline 4 & $\begin{array}{l}\text { Competently conducting church } \\
\text { board meetings }\end{array}$ & 8 & 25.0 & 14 & 43.8 & 10 & 31.3 & & - & 2.97 \\
\hline
\end{tabular}


supported theologically as well as in contemporary church growth literature. 1

The fifth priority factor, "Overseeing and supporting the leaders of each department or division of the church" (3.44 median score) ranked only a little higher than "Promoting and synchronizing activities of all divisions of the church" ( 3.26 median score), which was seventh in order of priority. Between these two, and with a median score of 3.27 , appeared the factor of "Being supportive of the administrative and departmental programs of the conference/ mission.". These three items ranked almost identically are obviously related, for the latter may be successfully accomplished only when the other two factors are in place since the conference and/or mission programs are expected to be implemented by the local church membership guided by their departmental leaders .

Although ranked as eighth in order of priority, the factor of "Being responsive to the suggestions of church officers and members" did result in a median score of 3.03 . This is encouraging. The remaining three factors, with only slightly lower scores, are closely related to those already discussed, since the decisions made in church business sessions ( 3.02 median score) and church board meetings (2.92 median score) frequently are dependent on the pastor's final word, which usually reflects the pattern of the conference/ mission administrators. These aspects deserve more study with a view to strengthening the creativity of the church leadership.

The last factor to be considered, "Perceiving and relating

${ }^{1}$ See for example, C. Peter Wagner, Your Church Can Grow (Glendale, CA: Regal Books Division G/L Publications, 1976), pp. 67-83. 
sensitively to cultural and sociological differences in people" (2.97 median score), ranks comparatively low. From personal observations I have noted that conflicts have arisen over this issue in more than one South American country. Perhaps as the educational level rises among church leaders, as it is bound to do, a greater awareness of this factor as contributing to successful ministry will develop.

Pastoral factors. The data in table 4 represent section $\mathrm{C}$ of the questionnaire, "Factors of pastoral work influential in determining pastoral productivity." According to the perceptions of the responding administrators, "Maintaining a proficient program of pastoral visitation" ( 3.77 median score) was of the highest importance. This item points to an area of potential tension between ministers and church members because most of the ministers in the S.A.D. have pastoral districts composed of several churches, groups, and companies, usually totaling several hundred or even more than a thousand members each. This reality, plus the tendency towards short-term pastorates, makes personal visitation by the pastor to every member's home physically impossible. Some pastors have partially solved this problem by organizing their elders, deacons, and other church officers for systematic vistation in the pastor's name. The pastor meets with this group of visiting leaders periodically and helps them minister to the needs of the members. Included in this is the work of the Sabbath School evangelistic units.

A11 but one of the remaining factors in this category deal with counseling, pre-marriage, family orientation, and support, and 
TABLE 4

EVALUATION OF THE CRITERIA THAT GOVERN THE CONCEPT OF MINISTERIAL PRODUCTIVITY IN ADVENTIST

MINISTERIAL FUNCTIONS ACCORDING TO SELECTED SAD UNION,' CONFERENCE, AND MISSION ADMINISTRATORS: PASTORAL FACTORS

\begin{tabular}{|c|c|c|c|c|c|c|c|c|c|c|}
\hline \multirow{2}{*}{\multicolumn{2}{|c|}{$\begin{array}{l}\text { Questionnaire } \\
\text { Item } \\
\text { No. }\end{array}$}} & \multicolumn{2}{|c|}{$\begin{array}{l}\text { Absolutely } \\
\text { Important }\end{array}$} & \multicolumn{2}{|c|}{$\begin{array}{l}\text { Very } \\
\text { Important }\end{array}$} & \multicolumn{2}{|c|}{$\begin{array}{l}\text { Somewhat } \\
\text { Important }\end{array}$} & \multicolumn{2}{|c|}{$\begin{array}{l}\text { Unim- } \\
\text { portant }\end{array}$} & \multirow{2}{*}{$\begin{array}{l}\text { Median } \\
\text { Score }\end{array}$} \\
\hline & & No. & $\%$ & No. & $\%$ & No. & $\%$ & No. & $\%$ & \\
\hline 1 & $\begin{array}{l}\text { Maintaining a proficient program } \\
\text { of pastoral visitation }\end{array}$ & 22 & 68.0 & 10 & 37.3 & & - & & - & 3.77 \\
\hline 4 & $\begin{array}{l}\text { Understanding and counseling pro- } \\
\text { ficiently teenagers and youth }\end{array}$ & & - & 13 & 41.9 & 17 & 54.8 & 1 & 3.2 & 3.35 \\
\hline 2 & $\begin{array}{l}\text { Being available for Christian } \\
\text { counsel and support }\end{array}$ & 6 & 18.8 & 24 & 75.0 & 2 & 6.2 & & - & 3.08 \\
\hline 7 & $\begin{array}{l}\text { Proficiency in organizing and } \\
\text { directing family workshops }\end{array}$ & 6 & 19.4 & 27 & 67.7 & 3 & 9.7 & 1 & 3.2 & 3.04 \\
\hline 3 & $\begin{array}{l}\text { Being available for counsel in } \\
\text { marital and family conflicts }\end{array}$ & 4 & 12.5 & 24 & 75.0 & 3 & 9.4 & 1 & 3.1 & 3.00 \\
\hline 5 & $\begin{array}{l}\text { Understanding and helping senior } \\
\text { citizens in their crises }\end{array}$ & 5 & 16.1 & 21 & 67.7 & 5 & 16.1 & & - & 3.00 \\
\hline 6 & $\begin{array}{l}\text { Proficiency in organizing and } \\
\text { directing pre-marriage seminars }\end{array}$ & 5 & 16.1 & 20 & 64.5 & 4 & 12.9 & 2 & 6.5 & 2.97 \\
\hline
\end{tabular}


al1 received relatively high median scores $(3.35,3.08,3.04,3.00$, and 2.97, respectively). The addition of a Department of Home and Family in the union conferences and some local conferences would appear to be a good beginning. Perhaps the most urgent need is to implement something more specific in counseling, as it is generally recognized that the one pastoral counseling course ministers receive in college is not adequate for the growing demands for counseling help.

The remaining factor, "Understanding and helping senior citizens in their crises" ( 3.00 median score), was considered important for ministers by the respondents. This ranking may reflect the fact that traditionally in Latin America the elderly are highly respected, as a rule, and valued by all who are younger, as well as by the ministers. (The elderly are usually cared for by their children with whom they live until death.)

Preacher/Evangel ist factors. The data in table 5 represent section $D$ of the questionnaire, "Factors influential in determining ministerial productivity of the preacher/evangelist." Ranking first in this section, according to the choices of the respondents, was "Training laity and organizing evangelistic efforts conducted by them" ( 3.76 median score). This is in s.trong agreement with the theological aspects of productivity in ministry as discussed in part 1, pp. 36, 44. Second in order of priority was the factor, "Organizing and conducting public evangelistic campaigns" (3.34 median score). This sequence appears to be logical in that the minister certainly cannot conduct such a campaign successfully 


\section{TABLE 5}

EVALUATION OF THE CRITERIA THAT GOVERN THE CONCEPT OF MINISTERIAL. PRODUCTIVITY IN ADVENTIST MINISTERIAL. FUNCTIONS ACCORDING TO SELECTED SAD UNION, CONFERENCE, AND MISSION ADMINISTRATORS: PREACHER/EVANGELIST FACTORS

\begin{tabular}{|c|c|c|c|c|c|c|c|c|c|}
\hline \multirow{2}{*}{\multicolumn{2}{|c|}{$\begin{array}{l}\text { Questionnaire } \\
\text { Item } \\
\text { No. }\end{array}$}} & \multicolumn{2}{|c|}{$\begin{array}{l}\text { Absolutely } \\
\text { Important }\end{array}$} & \multicolumn{2}{|c|}{$\begin{array}{l}\text { Very } \\
\text { Important }\end{array}$} & \multicolumn{2}{|c|}{$\begin{array}{l}\text { Somewhat } \\
\text { Important }\end{array}$} & $\begin{array}{l}\text { Unim- } \\
\text { portant }\end{array}$ & \multirow{2}{*}{$\begin{array}{l}\text { Median } \\
\text { Score }\end{array}$} \\
\hline & & No. & $\%$ & No. & $\%$ & No. & $\%$ & No. $\%$ & \\
\hline 4 & $\begin{array}{l}\text { Training laity and organizing evan- } \\
\text { gelistic efforts conducted by them }\end{array}$ & 21 & 67.7 & 9 & 29.0 & 1 & 3.2 & - & 3.76 \\
\hline 3 & $\begin{array}{l}\text { Organizing and conducting public } \\
\text { evangelistic campaigns }\end{array}$ & 13 & 41.9 & 16 & 51.6 & 2 & 6.5 & - & 3.34 \\
\hline 2 & $\begin{array}{l}\text { Maintaining a good attendance at } \\
\text { regular scheduled church meetings }\end{array}$ & 10 & 32.3 & 20 & 64.5 & 1 & 3.2 & - & 3.22 \\
\hline 1 & $\begin{array}{l}\text { Being perceived as an excellent } \\
\text { preacher }\end{array}$ & 2 & 6.5 & 15 & 48.4 & 14 & 45.2 & - & 2.59 \\
\hline
\end{tabular}


without efficiently utilizing the several ministries of the laity, especially since he normally does not have a paid staff of evangelistic associates.

Last among the items in this category was "Being perceived as an excellent preacher" (2.59 median score). This may reflect an evaluation of the form of the question rather than of the significance of the preaching task.

Statistical measurements. The data in table 6 represent section $E$ of the questionnaire, "Statistical measurements influential in evaluating ministerial productivity." The first four factors ranked in descending order of priority by the respondents are: (1) "Number of workshop and training seminars conducted (3.37 median score), (2) "Number of evangelistic campaigns conducted by the laity" (3.33), (3) "Number of people baptized" (3.26), and (4) "Maintaining [of an] accurate active membership record" (3.26).

Next in order of priority was the factor, "Percentage of members participating in the minister's evangelistic activities." This may be perceived as a modeling system for educating the laity, as supported theologically (part I, pp. 18, 36, 49). The "Number of evangelistic campaigns conducted by the minister" was perceived by the respondents as being quite important ( 3.00 median score). That it appeared lower on the list may indicate the view that more important is the enabling and providing for the increase of the 'Taity's involvement in their own campaigns.

Ranked last as a measurement of minister's productivity was the factor dealing with the "Number of new members from different 
TABLE 6

EVALUATION OF THE CRITERIA THAT GOVERN THE CONCEPT OF MINISTERIAL PRODUCTIVITY IN ADVENTIST MINISTERIAL FUNCTIONS ACCORDING TO SELECTED SAD UNION, CONFERENCE, AND MISSION ADMINISTRATORS: STATISTICAL MEASUREMENTS

\begin{tabular}{|c|c|c|c|c|c|c|c|c|c|c|}
\hline $\begin{array}{l}\text { Questi } \\
\text { Item } \\
\text { No. }\end{array}$ & naire & $\begin{array}{l}\text { Abso } \\
\text { Imp }\end{array}$ & $\begin{array}{l}\text { utely } \\
\text { rtant }\end{array}$ & & $\begin{array}{l}r y \\
r \operatorname{tant}\end{array}$ & $\begin{array}{l}\text { Son } \\
\text { Impc }\end{array}$ & $\begin{array}{l}\text { ewhat } \\
\text { rtant }\end{array}$ & & im- & $\begin{array}{l}\text { Median } \\
\text { Score }\end{array}$ \\
\hline & & No. & $\%$ & No. & $\%$ & No. & $\%$ & No. & $\%$ & \\
\hline 5 & $\begin{array}{l}\text { Number of workshops and training } \\
\text { seminars conducted }\end{array}$ & 14 & 43.8 & 16 & 50.0 & 2 & 6.2 & & - & 3.37 \\
\hline 4 & $\begin{array}{l}\text { Number of evangel istic campaigns } \\
\text { conducted by the laity }\end{array}$ & 13 & 40.6 & 18 & 56.3 & 1 & 3.1 & & - & 3.33 \\
\hline 1 & Number of people baptized & 11 & 35.5 & 19 & 61.3 & 1 & 3.2 & & - & 3.26 \\
\hline 7 & $\begin{array}{l}\text { Maintaining accurate active } \\
\text { membership record }\end{array}$ & 12 & 37.5 & 17 & 53.1 & 3 & 9.4 & & - & 3.26 \\
\hline 9 & $\begin{array}{l}\text { Percentage of members participating } \\
\text { in evange } 7 \text { istic activities con- } \\
\text { ducted by the minister }\end{array}$ & 11 & 34.4 & 18 & 56.3 & 3 & 9.4 & & - & 3.22 \\
\hline 8 & $\begin{array}{l}\text { Per capita increase of tithes and } \\
\text { offerings }\end{array}$ & 9 & 28.1 & 21 & 65.6 & 2 & 6.2 & & - & 3.16 \\
\hline 3 & $\begin{array}{l}\text { Number of evangel istic campaigns } \\
\text { conducted by the minister }\end{array}$ & 7 & 22.7 & 17 & 54.8 & 7 & 22.6 & & - & 3.00 \\
\hline 6 & Accurate record of church dropouts & 4 & 12.5 & 23 & 71.9 & 5 & 15.6 & & - & 2.97 \\
\hline 8 & $\begin{array}{l}\text { Number of new members from different } \\
\text { cultural and socio-economic back- } \\
\text { grounds }\end{array}$ & 3 & 9.7 & 15 & 48.4 & 12 & 38.7 & 1 & 3.2 & 2.66 \\
\hline
\end{tabular}


cultural and socio-economic backgrounds" (2.66) median score).

Al though responses with respect to statistical measurements provide us with clues as to how ministers in the SAD might be evaluated, they should not be seen as constituting the full picture since qualitative elements are less accessible to measurement.

Those factors ranked high reflect the position that the pastor's role in equipping the laity is seen as preeminent. One goal of such activities, it would appear, is that new members be baptized into the church.

The pastor, while regarded as an evangelist as well, is not inevitably evaluated on the basis of the number of his own evangelistic campaigns.

Surprisingly, the keeping of accurate membership records is ranked high, reflecting perhaps the importance of accurate records as a part of a reporting system up the line to the world headquarters where numerical growth, naturally, is closely monitored.

\section{Subjective Evaluation of Ministerial Effectiveness}

In this section of the chapter, an attempt is made to gather clues and suggestions that would permit some understanding of the expectations of SAD ministers and administrators regarding ministerial effectiveness. To survey or interview a valid number of SAD workers would be beyond the scope of this project. Furthermore, it is recognized that the bits and pieces here presented do not give a total picture. They are a modest effort at sketching a picture from which some tentative conclusions may be drawn. 
These subjective evaluations include: (1) a description of evaluation questionnaires used in three unions, (2) interview with SAD workers currently at Andrews University, and (3) case studies derived from the experience of two ministers in Brazil.

Ministerial Evaluation Questionnaires

Three evaluation questionnaires used in four different unions of the SAD are analyzed. A full translation of each appears in the appendices.

Evaluation instrument of Union C (see appendix $B$ ). This rather formidable instrument of eleven pages has sixty-five separate items to which the minister responds (the last five items he and his wife respond to as a couple). The current instrument carries a place for the signature of the "participating conference president" for the years 1982-1987. The intent, apparent7y, is that an ongoing record with possible trends be provided. The process is that of a personal interview.

Translated into English the questions frequently come across as somewhat "loaded." For example, the first section is labeled "A well-balanced program." The second item in the section reads: "Your dedication to the yearly program of the district is: (very good, good, must improve).". Another question probes the pastor with respect to "Study and research dealing with evangelism" to which he may reply checking "regularly," "often," or "never." Another question asks, "Do you send (board-evaluated) church departmental reports to the conference with your observations since you are the 
administrative representative of your district?" (To which he may reply "regularly," "occasionally," "never.")

The categories covered would indicate expectations involving the following role functions of the minister: evangelism, pastoral functions (calling and counseling), lay training, and teaching and administration. There are no questions dealing with preaching or leadership in the corporate worship of the church. Evangelism is given priority.

When one remembers that these ministers, almost without exception, are in charge of several churches, a survey of this instrument gives one the feeling that such a pastor could well experience role overload. Other activities recommended are: twenty Bible studies weekly and twenty pastoral calls weekly; church school visits twice a week. In addition the pastor is expected to participate in school programs, parent-teacher meetings, and board meetings. He is expected to review the church treasurer's books once a month and to conduct evangelistic campaigns twice yearly, with at least 6 percent of the membership involved. Friday is usually a day of maintenance, personal affairs, and Sabbath preparation. The Sabbath is the pastor's busiest day, as noted in the evaluation form.

As to administrative styles, one might easily read too much into this process of evaluation; the atmosphere of these sessions would naturally depend on the way the church official(s) moved through the items. Simply reading these questions (many of which are somewhat personal and probing in nature) and the responses to which the interviewer is confined, one might conclude that the administrative style would be quite paternalistic. It would appear that the emphasis 
on reports, conference programs, church manuals, as well as questions regarding attitudes toward authority, would be perceived by pastors as somewhat authoritarian.

Ministerial evaluations of Union D (see appendix $C$ ). This evaluation instrument is used by two Union Conferences. It is designed to be given by an administrative commission but has also been administered by the conference president and sometimes by the union president.

Because of my personal acquaintance with these two Unions, I have heard numerous comments about the evaluation. Beginning workers usually accept it as routine, but some more experienced workers complain about questions of a more personal nature (those dealing with family budget, the wife's job, personal property, books bought and read, details about personal professional equipment and material, including kind of transportation and confessing possible personality conflicts with colleagues or church brethren). In spite of being quite personal, it has been acknowledged that this evaluation form has been helpful for personal evaluation and selfimprovement.

Some aspects of this evaluation might also contribute to a perception on the part of pastors of a paternalistic denominational attitude toward the field workers. A statistical report which concluded the evaluation process yields clues as to criteria for ministerial productivity. Figures were to be entered for each month of the year on the following items:- (number of) seminars, (home) Bible studies, meetings attended, pastoral calls, literature 
distributed, number of people baptized. (Perhaps the "literature distributed" items would be least appreciated in that it might be thought of as information to be gathered from the laity, not from pastors.)

The instrument does reflect an interest in the pastor's ongoing self-improvement through study, even inquiring how many books the minister had read during the year. An open-ended question asks, "What suggestions would you make to the administration for improving the effectiveness of your work?"

\section{Evaluation instrument of Union E (see appendix D). A} comprehensive evaluation process involving ministers of this field has been in place since 1981. A rather detailed instrument is provided all ministerial workers. The process begins with selfassessment on the part of the ministers on the basis of this instrument. In a follow-through visit from a conference official the minister is interviewed with the categories of the instrument providing the basis for discussion. Later, at a general "worker's meeting," general observations are shared with all the assembled ministers by the conference officials for analysis and discussion.? The purpose is overall workers' performance improvement.

The instrument covers the broad categories of one's spiritual qualities, intellectual capacities, emotional (psychological?) make-up, work (vocation?) and industry, human relationships, preferences and aptitudes (vocational), health and family. Each of these categories

${ }^{1}$ This information shared by a minister from that field, now a graduate student at Andrews University. 
identifies specific aspects which may be described under five grade levels, e.g., superior, excellent, good, fair, poor. Examples under spiritual qualities are "humility," "fervor/enthusiasm," "personal devotion." One may evaluate "fervor/enthusiasm" in grade levels from "very fervent and enthusiastic" to "apathetic and indifferent" (see appendix D).

Under intellectual qualities the worker is expected to evaluate himself with respect to intelligence, Biblical knowledge, ability to preach and write, etc.

Under preaching, one may be graded from "outstanding" (consistently presenting clear, uplifting messages) to "poor" (sermons with little significance). Another section asks the minister to assess himself with respect to his emotional reactions--"very controlled, even-tempered" to "easily irritated, volatile," his adaptability to change (and to moves), his reactions to praise and criticism, etc. In another section he is asked to evaluate himself with respect to his work: ability to schedule and organize his work, personal initiative, his attitude toward his work. In the section under "Human Relationships" he is asked among other things to evaluate his leadership style--from "excellent leader who persuades without force" to grade level 5, "influence, rejected as leader." Other aspects include "fellowship and team spirit" and "self-concept." Role functions of the pastor which are apparently esteemed by the evaluators are subsumed under "Preferences and aptitudes" and include the following: public evangelism, personal evangelism, teaching, youth work, pastoral visitation, church administration, mobilization of the laity. Preaching is not referred to directly in 
this section. A final section deals with the pastor's family life and personal finances. He is asked to evaluate the standing of his family in the congregation, his wife's influence in the church and home, and the perceptions that might exist concerning his children. On the matter of personal finances he is asked to grade himself between "Always follows a budget; is never in debt" and "Lives on advanced earnings; is always in debt."

As noted, this instrument is indeed comprehensive, generally covering a 11 the roles and functions associated with the work of the pastor. It is not possible to draw precise conclusions with regard to the weighing of the various criteria for effectiveness in ministry. Although the traditional functions of the pastor are evaluated, there are no indications as to what value is placed on anyone of them. Heavy emphasis is placed on the minister as a person--his spiritual, intellectual, and emotional fitness for his calling. Again, the value of this evaluation, it would appear, hinges on the tact and skill with which it is carried out.

\section{Interview with Former $S A D$}

\section{Leaders at AU}

Three doctoral candidates enrolled at Andrews University have served in and are under appointment to the SAD. These men have all served in the pastor-evangelist role and in denominational departments including the office of ministerial secretary on the local and union conference levels. In discussions held with these men regarding their perceptions respecting ministerial effectiveness in their fields and eliciting their personal views, some data useful to our purposes emerged. Responses were of a general nature tending 
more to suggest ways the productivity of ministers might be improved, and only indirectly hinting at criteria for effectiveness which might actualiy prevail. There was agreement that programs of continuing education were urgently needed to equip the ministers for service among all class levels. One suggested that the middle and upper classes were left almost unevangelized because of the cultural or educational inadequacies of many pastors. ${ }^{1}$

The role of the ministerial director was seen as crucial in this area since this office has the responsibility of continuing education for ministers. Resource persons must be models for evangelism, pastoral nurture, preaching, and church leadership. Their field visits to pastors should involve help in problem-solving, and enabling through instruction and actual demonstration. Many pastors could be greatly benefited by being assisted in an evaluation of their daily schedule and by practical pointers on time management. Indeed, the ministerial director, when seen as the pastor's friend and advocate, would be in a position of advantage to lead the pastor in processes of friendly, discreet self-evaluation. The evaluation process, it was suggested, should signal rewards for effectiveness in areas beyond those which can be statistically evaluated (such as the number of members added or church buildings erected). The use of guilt to stimulate numerical goals was rejected. One spoke of "statistical pressures". for rapid achievement of numerical quotas as contributing to spiritual and qualitative superficiality in ministry.

\footnotetext{
I Interview conducted at Andrews University, Berrien Springs, Michigan, February 1, 1983.
} 
The ministerial secretaries must be able to provide Christian support to field workers, rather than (as is sometimes the case) be viewed as informers bearing negative reports to the conference administration. Their visits, when seen as "administrative" visits, one suggested, may create pressures which hinder rather than help.

There was agreement that a ministry which encouraged congregational autonomy with respect to goals and programs would encourage qualitative as well as quantitative church growth. It was urged that the local church be given freedom to develop plans most appropriate to its immediate context and needs.

\section{Case Studies}

It was thought that some useful insights might be provided by responses from a few selected pastors whose experiences might be deemed representative of those of the general run of workers in the field. Letters were written to five pastors of our acquaintance requesting a brief career overview and self-evaluation of the pastor's perception of the effectiveness of his ministry. Admittedly, this is an unscientific and subjective approach. Two ministers responded. It was decided to include their stories since they provide somewhat of a study in contrast and, in our opinion, are not atypical.

\section{Case study: Pastor "A. After concluding his theological} training in college, Pastor $A$ was assigned a district of churches in January of 1967. His first four years of ministry consisted of the following: first district, seven months; second district, five months; third district, eleven months; fourth district, twenty-three months. At that point, apparently concluding he did not have an 
aptitude for the ministry, the conference committee asked him to take a vocational test. This test revealed that his aptitudes were in (1) journalism and communications, (2) business and administration, and (3) medicine. He was sent to teach bookkeeping at the conference boarding academy. During his second year there the same president who had encouraged his withdrawal from the ministry encouraged the conference committee to invite him to return as pastor of an important district of the conference. Pastor $A$ turned this down and remained at the school for another three years and seven months.

When a new conference president took office, Pastor $A$ returned to pastoral work, serving three and a half years in a district where he apparently experienced a productive ministry with a good record of baptisms and financial increase. During this period an addition was made to the church elementary school and a pastoral apartment was built without financial help from the conference. During this same period, Pastor A was ordained to the ministry.

He next served as director of the Stewardship and Education Departments of the mission for a year. He regarded this as a good experience. He then accepted a call to be dean of men at the union college, which, in his words, "was very hard work, but also very valuable experience." Following that he was called by a conference in another union to be school treasurer. A year later he became the secretary of the legal department of the conference, a position he held for seven months. In July 1982 he became the secretarytreasurer of one of the missions the position he still held at the time of his letter, December 4, 1982. Along with his treasury work 
and the supervising of construction of the mission's new office building, he has also conducted an evangelistic series in which eight-two persons were baptized.

Apparently the years have amply demonstrated that he was a success in the ministry, in spite of a degree of instability at the beginning. In his letter he states:

During the first four years of my ministry I never received a single warning or any constructive criticism. The first time I was aware of any problem was when the president came to fire me. Twice I was about to leave the employ of the organization but remained, thinking that God might be able to use me, even with my personal limitations, in some humble capacity. I only remained in the work because I was sincerely striving to serve God and not man. I await my reward and a just judgment from Him and not from man.

An analysis of Pastor A's years of service reveals that he was moved eleven times in sixteen years, averaging only sixteen months per assignment. During the crucial initial phase of his ministry he was placed in a district by himself with no experienced minister to help him and was changed four times in forty-two months. It must be remembered that during this time he also might have had to adjust to marriage.

Even though Pastor A feels self-fulfilled at present, it should be noted that there were at least eight changes of functions in his ministry: from pastor to teacher, to pastor, to departmental director, to dean of men, to school treasurer, to legal association secretary, and finally to secretary-treasurer of the mission. This indicates a two-year average stay in each function. The question naturally arises, "What measure of instability does such a situation bring to the minister's personal and family life as well as to church 
members who fail to receive any in-depth training for service in these brief stints of a pastor.

It would appear that inadequate orientation to ministry, a lack of internship training, frequent moves and changes not of his own choosing all contributed here to a period of unproductivity, as set against our stated criteria. Persistent endurance eventually revealed a potential for effective ministry.

\section{Case study: Pastor "B". Pastor B began his ministry} assisting in an evangelistic campaign in a large capital city. During the eleven months he was doing this he prepared forty persons for baptism. He then went to a pastoral district for three years, baptizing 149 persons and starting a new church building. In his second pastoral assignment (again of three years), he baptized 138 persons and opened three new churches in unevangelized cities. He then accepted a call from another conference, remaining three years in his district. There he baptized 334 persons, led in building a new church, established two elementary schools, constructing the building for one of them and purchasing property for further construction.

His next pastorate (in an Italian-Catholic area largely unentered by the Seventh-day Adventist Church) consisted of two small congregations. His term here lasted four years. After two years the conference wanted to move him because of the small number of converts, but he persuaded them to allow him to remain long enough to bring his goals for the area to fruition. At the end of four years he was moved against his personal wishes but left behind 149 
persons baptized, two groups organized into churches, one new church dedicated, and property purchased for the second church building. Two new congregations had been established in two neighboring cities and a new chapel was built.

At the time of Pastor B's letter he had been in his latest pastorate a total of five years, for which he reports 280 persons baptized, two new churches and three new chapels built in new cities, one church rebuilt, an elementary school built and opened, and four evangelistic campaigns held with the help of church members and membership. In his four-page letter he said, "My plan has been to establish new churches with their own buildings in places as yet unevangelized." Commenting on the difficulties and losses in his various districts he states:

The problem of frequent moves with their consequent disruption of work is something that troubles me greatly. One does, and another does not continue the work started. This delays and hinders growth in many places. In penetrating new frontiers where it is more difficult and slower to establish a new church, I believe the administrators should give more support rather than looking only for immediate results.

Pastor $B$ resisted being moved before objectives for his churches could be achieved, especially in his last three pastoral assignments.

Throughout his nineteen years of ministry, he has to date, baptized 1,090 persons, many of whom were from the middle and upper classes--lawyers, professors, physicians. Many young people in his districts who were sent to Adventist colleges are today workers in the denomination. He calculates a drop-out rate of 10 to 15 percent.

An analysis of his report for these nineteen years reveals five changes of districts (after the first year of internship), with 
an average of 3.25 years in each district and an average of 57.3 persons baptized per year. Nine new congregations were formed, five churches and six chapels built, one church rebuilt, four new elementary schools established, and two elementary school buildings constructed. The report also reveals concern about the church's emphasis on quantitative results and his awareness of always being evaluated by numerical and statistical measurements.

One might conclude that these longer terms gave Pastor $B$ the stability needed for implementing long-range plans and a higher reportable productivity.

\section{Comparison of the Two Case Studies}

It is of interest to note that neither of these two pastors mentioned anything about important achievements which cannot be easily measured statistically. A comparison of the two cases might provide some clues regarding mission/conference administrative factors affecting productivity.

Similarities. Both Pastor A and B had the same basic college preparation. Both indicated that they were pressed to meet numerical goals. Both faced pressures threatening to shorten their pastoral terms. Both resisted frequent moves, al though neither took this position in the first years of his work, perhaps waiting for greater stability before asserting themselves. Both showed improved productivity and received greater personal satisfaction in pastorates of longer duration.

Contrasts. Pastor A was placed immediately after college into a district with no previous internship experience, while 
Pastor $B$ worked a year under an experienced evangelist. Pastor $A$ changed districts four times in his first four years while Pastor B was moved four times in his first nine years. Pastor A apparently did not feel free to report numerical achievements in his letter, while Pastor $B$, with relatively good numerical accomplishments to report, felt no such hesitancy. Pastor A seems to have started his ministry under an administration concerned about immediate results, for when he failed to achieve their expectations as rapidly as they felt he should, a change was immediately suggested. Pastor $B$ apparently began under an administration that showed concern for enabling ministers through an internship opportunity, and which permitted (albeit apparentiy somewhat reluctantly) longer pastorates. With admitted limitations, some inferences may be drawn from these two cases concerning administrative factors that tend to interfere with ministerial leadership in the parish as affecting productivity. McDonough argues, "Heal thy church growth will not happen in a church unless the church is being led by a growing pastor." 1 This naturally depends much upon a conference administration willing to provide a healthy working environment for the crucial beginning processes of ministry. Spiritual support and understanding are particularly needed by beginning pastors. This is in accordance with the high spiritual nature of the church and in harmony with the organic mission of the church, for only completely equipped ministers reproduce equipped lay ministers for productivity. It also appears from even this limited comparison,

TReginald M. McDonough, "Growing Ministers Growing Churches," Church Administration Magazine, February 1983, p. 2. 
that the longer the pastoral term, the greater the productivity. Perhaps around five years would be the ideal for a longer pastorate as perceived by the SAD administrators! responses to the questionnaire.

\section{Summary}

The open-ended section of the questionnaire sent to SAD administrators suggests that the concept of an effective minister embraces spiritual nurture, enabling, motivating, planning, delegating responsibilities, and evaluating the subsequent performance. There was nearly total agreement that best results are obtained when the church sets its own goals and carries out its own evaluations, but there was no unanimity regarding how this should be done. A few respondents seemed less than convinced of the importance of the pastor's fully involving the members in the process of goal-setting or evaluation, feeling instead that it is the prerogative of the pastor or even the conference.

In the objective questionnaire, the most important personal factors for ministerial effectiveness were considered to be a meaningful devotional life, having a sense of calling to the ministry, and having a good marriage. In the area of leadership and administration the most important ministerial functions were seen to be the conducting of training courses for winning and establishing new members and instructing church officials and lay members in Christian leadership. Pastoral functions deemed to be of greatest importance were pastoral visitation and youth work. In the area of preaching and evangelism, the most important functions were 
reported to be the training of laity for public evangelism and the conducting of public evangelism campaigns. The four numerical measurements considered to be of most importance in the evaluation of ministerial effectiveness were: (1) number of workshops and training seminars conducted, (2) number of evangelistic campaigns conducted by lay members, (3) number of people baptized, and (4) percentage of members participating in evangelistic activities. In addition, the keeping of accurate records was seen as very important. The evaluation questionnaires used in four of the SAD unions suggest high expectations, on the part of conference administration, not only in the number of hours dedicated to work but in the varied activities. Ministers seem to be expected to report precisely on their study and reading habits, on evangelism--which has obvious priority, on lay training, pastoral visitation, and number of studies and baptisms. Personal matters, such as finances and family relations, also come in for review. The instruments alone are not sufficient to determine the weight given to each factor in the evaluation. Furthermore, the way in which the evaluation is conducted could well affect both the attitude and the response of the minister evaluated.

The interview with SAD personnel currently studying at Andrews University yielded information regarding the importance of continuing education for ministers. These workers also stressed the importance of the role of the ministerial director of the conference or union in assisting the minister to become more effective. The use of numerical goals was considered objectionable because of the pressure it applied to ministers. 
The case studies involved two pastors: one who was moved often and apparently given little positive reinforcement; the other a minister who had stayed longer in each job and had achieved some measure of success. The main differences between the two were the length of time in a given ministry, the internship under a successful evangelist (Pastor $B$ ), the apparent lack of support for struggling ministers (Pastor A), and the pressures of immediate achievements (Pastor B). Admittedly, limited background and information makes it difficult to generalize the implications of these case studies.

In synthesis, SAD ministers and leaders seem to be concerned with achieving--in the area of soul winning, lay training, church administration, and pastoral functions.

\section{Conclusions}

It is important that the Seventh-day Adventist Church today lay solid theological foundations upon which to build its concept of an effective ministry. In the process, every criterion governing effectiveness in ministerial performance must be placed in proper reference to that foundation.

The nature of the church demands high levels of spiritual commitment on the part of its members and its leaders. Awareness of the spiritual dimension is reflected in the SAD leaders' responses to our survey as well as in their minister-evaluation processes. The question might be raised whether these wholesome emphases on the devotional life of the minister as well as the implications for emphasis on leading congregations to spiritual vitality through worship and Bible study may be somewhat diluted by the heavy demands and emphases on the instrumental or activity-related dimensions of 
the minister's responsibilities: these are familiar tensions with which every minister and church organization must cope.

The spiritual nature of the Church as the Body of Christ places high demands upon those responsible for its earthly expression for faithful stewardship. The minister is responsible for the best development and use of his gifts, talents, health, time, and resources for the sake of the Church. Likewise, the talents, gifts, and resources of all members must be identified and enhanced through instruction and training for ministry. These emphases are reflected both in the survey responses and interviews.

There is a desire expressed on the part of former church leaders of the SAD now doing graduate work that ministers be given opportunities for continuing education, and that the director of the office of ministerial department be invested with the responsibility of overseeing and coordinating such opportunities.

The contemporary emphasis in the North American Church on the doctrine of spiritual gifts is well supported in New Testament ecclesiology. It is an emphasis that appears not to have had a similar impact as yet in the South American Division of Seventh-day Adventists.

Images of the church support the concept that the visible church carries on the ministry of Christ on earth--we are his "hands and feet" for ministry. The high priority on evangelistic emphasis on the part of church leaders is certainly justified. Again, the question one might ask is whether the heavy emphasis on evangelistic activities and its measurable results are at the expense of the balancing need for Christian nurture and grounding of the believers 
in the Christian faith. Pastoral care and equipping for "maintenance" needs fall lower on the reported priority list, although one finds strong emphasis in the New Testament for the edification and discipling of the believers.

In recent years, church leadership in the North American SDA church has supported greater autonomy on the part of the local congregation in articulating its mission, goals, and objections as in the "Faith, Action, Advance" program and documents and in the promotion of the "Caring Church Model." These concepts, we believe, have New Testament support in those passages dealing with the images and nature of the church. While there appears to be growing support in the SAD for the idea that motivation levels rise where the local church sets its own goals and carries out its own evaluations, there is some hesitancy and ambivalence regarding the importance of these concepts, or how to proceed in implementing them. The democratization processes, it would seem, must be given time, taking into account historical traditions and cultural differences.

\section{Recommendations}

Below are offered recommendations for the enhancement of effectiveness for ministry in the SAD growing out of this study:

1. The importance and value of spiritual foundations for ministry in the congregation and the life of the minister must continue to be affirmed and emphasized.

2. The concern of South American SDA leaders with the minister's family. life and importance placed on a good marriage needs to be followed up with specific responses. Attention should be given 
to preparing literature, workshops, and academic courses in the seminaries and colleges of the church on the topic of marriage and family. Marriage enrichment programs as being developed by the church in the U.S. could well be adapted and introduced in this field.

3. There should be careful planning of the young ministers' internship period, giving them as broad an exposure to the different facets of ministry as possible under pastor-supervisors and mentors trained for this supervisory work. If the worker is freed from anxieties regarding immediate numerical results and nurtured in a climate of acceptance and encouragement, the likelihood of his maturation toward effective ministry would presumably be enhanced.

4. Because pastors generally serve multi-church districts in this field, the minister's roles need restudy to include this dimension, normally neglected in the literature and in the academic courses designed to instruct the pastor in his role functions. Instruction of young pastors should emphasize understanding and skills for adult education and training for leadership in these churches.

5. The current emphasis on ministry flowing from one's spiritual gifts as found in the U.S. must be given similar prominence in South America where lay members are already active, but adapted to their reality. This would help broaden concepts of ministry and would lift to greater awareness the importance of mutual member-to-member ministry, as well as evangelistic activities.

6. It is suggested that the current North American Division emphasis on broadening the base of lay-participation in goal setting and decision making (modified "Management by objectives") 
outlined in the "Faith, Action, Advance" manuals be also given in the SAD.

7. The role of conference ministerial directors as the "Pastor's Pastor" must be strengthened. Training experiences for this key function such as the ones provided by the Andrews University Doctor of Ministry degree program extension courses should be made available to these men where possible.

8. It is recommended that the concept of ministerial support groups as noted in Luiz Silva Melo's D.Min. project dissertation ${ }^{1}$ be implemented and tested for its relevance for the ministerial workers not only in Brazil but in the other areas of the SAD.

9. Evaluation procedures should be worked out with the ministers to eliminate threat factors as much as possible. The process should be broadened to include those dimensions given significant ratings referred to earlier in this chapter.

10. Motivation and worker satisfaction, it is suggested, would be enhanced by the following:

a. A recognition and affirmation of differences among workers. The doctrine of spiritual gifts and the fact of differences in the natural and acquired gifts and talents point to the need for making allowance for differences in workers. These differences must be affirmed and supported.

'Luiz Silva Melo, "A Rationale and Suggested Program for Minister's Support Groups for Seventh-day Adventist Pastors in Brazil" (D.Min. project dissertation, Andrews University, 1981). 
b. Making allowances for differences in the geographical areas as to susceptibility to or lack of openness to the Adventist message. A recognition of these differences in local needs should be conveyed to the workers.

c. Allowance for differences in congregations which might affect numerical output should be conveyed. In a district with several already established congregations, the churches become the nuclei of productivity. If their members are efficiently enabled in church leadership and in winning and nurturing new members according to their natural talents and spiritual gifts, they can move ahead by themselves with less pastoral involvement. Their effective ministries become part of the minister's productivity.

d. It would seem to be important that there be considerable patience with slow starters who may be falling behind in measurable results. Frequent moves may produce discouragement in the ministry and passivity in the churches. Terms of at least five years seem to be indicated. 
APPENDICES 
APPENDIX A

QUESTIONNAIRE AND COVERING LETTER. 
Andrews University

Berrien Springs, Michigan

November 3, 1982

Dear Pastor:

May the Lord's blèssings be yours in you important administrative duties is my prayer.

Last March I concluded my academic program for the Doctor of Ministry course at Andrews University and in April we accepted a call from the Inter-American Division to teach at the ColomboVenezuelan Union College in Medellin, Colombia. I spent about four months there, returning on October 25 to finish my dissertation and defend it.

I urgently need your help and understanding in answering the enclosed questionnaire. The word "production" or "pastoral productivity" may be considered to be synonymous with the words "success," "accomplishments," "results," etc. I will greatly appreciate your taking a few minutes to answer and return it, if possible today. Your contribution will be extremely valuable to me. I will be glad to let you know the results of this research when it is completed. These data will be processed by computer. Again, I ask you earnestly to return it at once, for which I express my gratitude and appreciation.

\section{Sincerely,}

Itamar Sabino de Paiva

Enclosure 


\section{UNA EVALUACION DE LOS CRITERIOS QUE GOBIERNAN \\ EL CONCEPTO DE LA PRODUCTIVIDAD PASTORAL \\ EN EL MINISTERIO ADVENTISTA}

¿Como evaluaría Ud. los siguientes factores que podrían influir en la productividad pastoral de un ministro, usando la siguiente escala de 4 a 1 ?
4. Absolutamente importante
3. Muy importante
2. Poco importante
1. Sin importancia

Ejemplos

Absolut. Muy Poco Sin

$\frac{\text { import. }}{4} \frac{\text { import. }}{3} \frac{\text { import. }}{2} \frac{\text { importancia }}{1}$

1. Haber nacido en un hogar rico.....4

2. Haber sido un buen estudiante ....4

3. Ser cristiano genuino ...........4

3

3

3

(1)

A. FACTORES PERSONALES QUE DETERMINAN

LA PRODUCTIVIDAD PASTORAL

1. Haber sentido el 11 amado para

el ministerio ...............4

3

2

1

2. Poseer una buena preparación académica .................

3

2

3. Gozar de buena salud.........4

3

2

1

4. Tener una personalidad atrayente.........................4

3

2

5. Tener entusiasmo y persuasión.,.4

6. Mantener un programa de trabajo, reposo y recreación equilibrado......................4

7. Mantener una vida de significativa devoción personal........4

8. Tener un matrimonio estable y feliz ....................4 
Absolut. Muy Poco Sin

import. import. import. importancia

9. Tener un programa consistente de estudios ...........4

3

2.

1

10. Organizar el trabajo de acuerdo con las prioridades ......4

11. Actuar por iniciativa propia e inmediatamente cuando es necesario ..................4

12. Ser hábil en resolver criteriosamente los problemas ....4

13. Reconocer las debilidades y aprender a dominarlas .......4

14. Hacer propios en forma personal los mensajes biblicos ...4

15. Hacer propios en forma personat los mensajes de E.G.

White ..................4

16. Mantener un equilibrio en las finanzas personales ........4

17. Ser eficiente administrador del tiempo ................4

B. FACTORES DEL LIDERAZGO Y ADMINISTRACION QUE DETERMINAN LA PRODUCTIVIDAD PASTORAL

1. Planear y conducir un programa distrital a largo, medio y corto plazo .....................

2. Desarrollar las actividades de todos los departamentos de la iglesia en forma sincronizada. 4

3. Cooperar con las promociones administrativas y departamentales de la Asociación o Misión .....................4 
Absolut. Muy Poco Sin import. import. import. importancia

4. Dirigir con eficiencia las reuniones de la junta de la iglesia .................4

5. Organizar y dirigir con eficiencia las reuniones de negocios de la iglesia .......4

6. Preparar y conducir cursos prácticos para ganar y confirmar nuevos conversos .....4

7. Enseñar liderazgo cristiano a los oficiales y hermanos de la iglesia ...............4

8. Supervisar y asesorar a los 1 ideres de los departamentos de la iglesia ..............4

9. Escuchar y atender las sugerencias de los oficiales y miembros de la iglesia ......4

10. Delegar responsabilidades y autoridad en los lideres de la iglesia ................4

11. Captar y ser sensible a las diferencias culturales y socioeconómicas de las diferentes personas ..............4

C. FACTORES DE ACTIVIDAD PASTORAL QUE DETERMINAN LA PRODUCTIVIDAD PASTORAL

1. Mantener un eficiente programa personal de visitación pastoral .....................4

2. Estar disponible para aconsejamiento y ayuda pastoral ....4

3. Estar disponible para aconsejar en forma personal a las parejas que tengan conflictos maritales o familiares ......4 
Absolut. Muy Poco Sin

import. import. import. importancia

4. Entender y aconsejar con ef $i$ ciencia a los adolescentes y jóvenes ..................

5. Entender y ayudar a los ancianos en sus crisis ...........4

6. Organizar y dirigir con eficiencia cursos pre-matrimoniales ..................

7. Organizar y dirigir con eficiencia cursos para familias..4

D. FACTORES DE PREDICACION $Y$ EVANGELISMO

QUE DETERMINAN LA PRODUCTIVIDAD PASTORAL

1. Ser un predicador sobresaliente.......................4

2. Mantener un alto indice de asistencia a las reuniones regulares de la iglesia .......4

3. Organizar y dirigir personalmente campañas de evangelización .....................4

4. Entrenar a los laicos y organizar esfuerzos evangelizadores dirigidos por ellos .....4

E. DETERMINANDO LA PRODUCTIVIDAD PASTORAL MEDIANTE LAS ESTADISTICAS ANUALES

1. Cantidad de personas bautizadas .....................4

2. Cantidad de bautizados provenientes de diferentes clases culturales y socio-económicas.4

3. Número de campañas evangelizadoras por el ministro .......4 
Absolut. Muy Poco Sin import. import. import. importancia

4. Número de campañas dirigidas por los miembros de la iglesia ....................4

21

5. Número de cursos de capacitación dados a los miembros ....4

$3 \quad 2 \quad 1$

6. Cantidad exacta de miembros que apostataron $\ldots \ldots \ldots \ldots \ldots 4$

7. Secretaría de la iglesia al día con el número exacto de miembros fieles y activos .......4

8. Crecimiento per cápita de diezmos y ofrendas ...........4

9. Porcentaje de miembros que toman parte en actividades evangelizadoras dirigidas por el ministro ..................4

\section{F. TENGA LA BONDAD DE CONTESTAR LAS SIGUIENTES PREGUNTAS}

1. ¿Como definiria Ud. su propio concepto de un ministro "productivo?

2. ¿Cuan importante considera Ud. los resultados cualitativos para evaluar la productividad del ministro? (Por ejemplo: La condición espiritual de la congregación).

Absolutamente importante Muy importante

Poco importante

Sin importancia

3. De acuerdo con su criterio, iquien deberia definir los blancos de la iglesia? (Marque con una $X$ )
1. Presidente
2. Secretario ministerial
3. Departamentales La administración
5. La iglesia(s) y grupo(s).Tocales. 
¿Podría darnos Ud. la razón de su respuesta?

4. ¿De cuantos años aproximadamente debería ser el período de trabajo pastoral del ministro en la iglesia o distrito?

Años

5. Por favor comente esta declaración: "El ministro debería ser evaluado por la experiencia total de su ministerio al fin de su período en la iglesia o distrito."

6. ¿Vería Ud. mérito en un sistema en el cual los oficiales y miembros de la iglesia contribuyeses en el proceso de la evaluación del ministro?

Si. No

¿Podría darnos la razón de su respuesta?

Favor de darnos sugerencias $u$ observaciones que podrian contribuir en el proceso de evaluar el éxito, los resultados o "productividad" pastoral de un ministro. 
EVALUATION OF THE CRITERIA THAT GOVERN THE CONCEPT OF PASTORAL PRODUCTION IN THE ADVENTIST MINISTERIAL FUNCTIONS

Evaluate these functions that could influence in the pastoral production of a minister on a scale from 4 to 1 .
4. Absolutely essential
3. Very important
2. Somewhat important
1. Unimportant

Please circle the number that best represents your appraisal.

Examples:

$$
\frac{\frac{\text { Absolutely }}{\text { essential }}}{4} \frac{\text { Very }}{3} \frac{\frac{\text { Somewhat }}{\text { import. }}}{2} \frac{\text { inport. }}{1} \text { import. }
$$

3

1. To be born into a wealthy home....4

2. To be a good student............4

3. To be a genuine Christian......... (4)

3

3

3

(2)

(1)

A. PERSONAL FACTORS INFLUENTIAL IN

DETERMINING PASTORAL PRODUCTION

1. Having a sense of calling to the ministry.............4

2. Having good acadenic preparation....................4

3. Enjoying good heal th.........4

3

2

4. Having an attractive personality.....................

5. Being enthusiastic and vibrant..................4

6. Maintaining a balanced program of work, rest and recreation..4

7. Maintaining a meaningfur devotional life.............4

8. Having a solid and happy marriage. 


\section{Absolutely $\frac{\text { Very }}{\text { essential }}$ import. Somewhat $\frac{\text { Un- }}{\text { import. }}$ import.}

9. Maintaining a consistent

program of study..........4

3

2

1

10. Organizing work according to priorities..............

11. Acting with promptness and initiative as necessity demands.................4

12. Solving problems with

rational criteria..........4

13. Perceiving ones weaknesses and learning how to overcome them....................4

14. Making proper personal appropriation of the Biblical messages.................4

15. Making proper personal appropriation of Ellen G. White's messages...................

\section{4}

3

3

2

17. Being efficient in personal time management.............4

B. FACTORS OF LEADERSHIP AND ADMINISTRATION

INFLUENTIAL IN DETERMINING PASTORAL PRODUCTIVITY

1. Planning and implementing long, medium, and short term church district programs..........4

2. Promoting and synchronizing activities of all divisions of the church................4

3. Being supportive with the administrative and departmental programs of the Conference/Mission...............4

4. Conducting proficiently the church board...............4

5. Proficiency in organizing and directing church business sessions. 


\section{$\frac{\text { Absolutely }}{\text { essential }}$ impory $\frac{\text { Somewhat }}{\text { import. }}$ Un-}

6. Preparing and conducting practical training courses for winning and establishing new members.....................

7. Instructing church officials and laity in principles of Christian leadership..........4

8. Overseeing and supporting the

leaders of each department of division of the church.........4

9. Being responsive to the suggestions of church officers and members....................

10. Delegating responsibilities and authority to the leaders and members of the church......4

11. Perceiving and relating sensitively to cultural and sociological differences in people...4

C. FACTORS OF PASTORAL WORK INFLUENTIAL IN DETERMINING PASTORAL PRODUCTIVITY

1. Maintaining a proficient program of pastoral visitation.....4

2. Being available for Christian counsel and support..........4

3. Being available for counsel in marital and family conflicts....4

4. Understanding and counseling proficiently teenagers and youth... 4

5. Understanding and helping senior

citizens in their crises.......4 4

6. Proficiency in organizing and directing pre-marriage seminars. 4

7. Proficiency in organizing and directing family workshops......4 


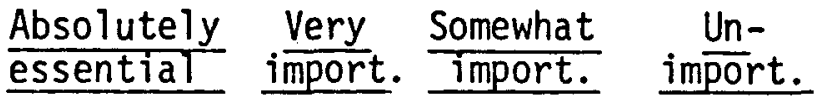

D. FACTORS INFLUENTIAL IN DETERMINING

PASTORAL PRODUCTIVITY OF

PREACHER/EVANGELIST

1. Being perceived as an

excellent preacher............4

3

2

1

2. Maintaining a good attendance

at regular scheduled church

meetings....................4

3

21

3. Organizing and conducting

public evangelistic campaigns...4

4. Training laity and organizing evangelistic efforts conducted by them...................4

E. STATISTICAL MEASUREMENTS INFLUENTIAL IN DETERMINING PASTORAL PRODUCTIVITY

1. Number of people baptized......4

2. Number of new members from different cultural and socioeconomic backgrounds..........4

3. Number of evangelistic campaigns conducted by the minister..................4

4. Number of evangelistic campaigns conducted by the laity...4

5. Number of workshops and training seminars conducted.........4

6. Accurate record of church dropouts.................. 4

7. Maintaining accurate active membership record............4

8. Per capita increase of tithes and offerings...............

9. Percentage of members participating in evangelistic activities conducted by the minister.......4 
F. PLEASE ANSWER THE FOLLOWING QUESTIONS:

1. How would you define the concept of a "productive" minister?

2. How important do you regard qualitative achievements in evaluating the minister's productivity? (e.g., spiritual condition of the congregation?)

Absolutely essential Very important Somewhat important Unimportant

3. In your opinion, who should establish the church goals. (Mark with an X).
1. President
2. Ministerial Secretary
2. Departmental Head
4. The Administration
5. The churches and local groups

Please comment on your answer

4. Approximately how long should the term be of a pastor in one church/district? Years

5. Please comment on the following statement: "A minister should be evaluated on his total experience in ministry in a given church/district rather than on the basis of a single good or poor year's work (or results)." 
6. Would you see merit in providing a system of evaluation for pastors including officers and members of the church in this process?

$$
\text { Yes }
$$

No

Please comment on your answer

7. Please offer any other suggestion or observation that might contribute to the process of evaluating the success, results, or productivity of pastors. 
APPENDIX B

EVALUATION INSTRUMENT OF UNION C 
NOMBRE

IISTRITO

ASOCIACION

Fechas de la Evaluación:

Participó el Presidente pastor:

1982

1983

1984

1985

1926

1987

I DEI EQUILIBRIO EN EL PROGRAMA

1. Su aplicación a un programa diario de actividades es:

\begin{tabular}{|c|c|c|c|c|c|}
\hline $\begin{array}{l}\text { Muy Bueno } \\
\text { Bueno } \\
\text { Conviene mejorar } \\
\ldots \ldots \ldots \ldots \ldots \ldots\end{array}$ & $\begin{array}{l}\square 82 \\
\square 82 \\
\square 82 \\
082\end{array}$ & $\begin{array}{l}\square 83 \\
083 \\
083 \\
083\end{array}$ & $\begin{array}{l}\square 84 \\
\square 84 \\
\square 84 \\
\square 84\end{array}$ & $\begin{array}{l}\square 85 \\
\square 85 \\
\square 85 \\
\square 85\end{array}$ & $\begin{array}{l}\square 86 \\
\square 86 \\
\square 86 \\
\square 86\end{array}$ \\
\hline
\end{tabular}

2. La aplicación al programa anual de su distrito es:
Muy Buena
$\square 82$
$\square 83$
$\square 84$
$\square 85$
$\square 86$
1] 87
Buena
$\square 82$
$\square 83$
[] 84
$\square 85$
86
$\square 87$
Conviene mejorar
$\square 82$
$\square 83$
ㅁ 84
085
ㅁ 86
ㅁ 87
......... $\square 82$
$\square 83$
$\square 84$
$\square 85$
$\square 86$
무

3. Practica diariamente su devoción personal (sugerencia:30'):
Regularmente
082
$\square 83$
082
$\square 83$
$\square 84$
$\square 85$
$\square 86$
口 87
Pocas veces
$\square 82$
$\square 83$
084
ㅁ 85
$\square 86$
ㅁ 84
$\square 85$
$\square 86$
$\square 87$
..........
$\square 82$
$\square 83$
$\square 84$
$\square 85$
$\square 86$
$\square 87$
$\square 87$

4. Los cultos familiares matutinos y vespertinos 108 realiza:
Regularmente
$\square 82$
ㅁ 83
a 84
$\square 85$
$\square 86$
085
084
ㅁ5
ㅁ 86
$\square 83$
$\square 82$
$\square 83$
$\square 84$
$\square 85$
$\square 86$
$\square 84$
085
$\square 86$
$\square 86$
$\square 87$
ㅁ 87
$\square 87$
0.82
ㅁ. 83
요 84

dia hábil para el estudio y la investigación, Ud. lo dedica:
Regularmente
$\square 82$
$\square 83$
$\square 84$
$\square 85$
085
$\square 86$
ㅁ 87
Ocasionalmente
$\square 82$
$\square 83$
$\square 84$
ㅁ 85
$\square 82$
$\square 83$
$\square 84$
085
$\square 84$
085
$\square 86$
ㅁ 87
Es imposible
$\square 82$
083
口 84
86
ㅁ 87
...........
$\square 86$
ㅁ 87
87 
6. El tiempo (sugerencia: 30') que dispone cada día hábil para familiarizarce con los Manuales de: Iglesia, Escuela Sabática, Asistencia Social, Reglamento de Educación, etc., Ud. lo dedica:
Regularmente
$\square 82$
口 8.3
$\square 84$
$\square 85$
$\square 86$
口 85
$\square 86$

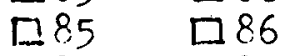
Pocas veces
다 82
$\square 83$
Doi.
585
$\square 86$
Lin
口 85
[1] 86
$\square 87$
$\square 87$
$\square 87$
$ㄷ 87$
$\square 87$

7. El tiempo (sugerencia:30') que dispone cada día hábil para atender los a suntos administrativos tales como correspondencia, búsqueda de presupuestos, envio de informes comentados, compra de materiales, mantener informada a la oreanización sobre sus actividades, etc., Ud. 10 dedica:
Regularmente
$\square 82$
$\square 83$
며 84
$\square 85$
口 86
$\square 84$
$\square 85$
$\square 86$
$\square 86$
Pocas veces
$\square 82$
$\square 83$
$\square 84$
$\square 85$
됴 86
$\square 84$
七8 8
[ㄷㅇ
$\square 87$
$\square 87$
무 87
$\square 83$
$\square 84$
口85
587
口87

8. Ud. hace ejercicios físicos ( 2 su esposa lo acompana?):
Regularmente
$\square 82$
$\square 83$
$\square 84$
1] 85
$\square 86$
$\square 84$
도
드86
$\square 87$
Ocasionalmente
0.2
$\square 82$
믈
$\square 84$
ㅁ 85
$\square 86$
ㄷ87
Nunca
[1 82
됴
$\square 84$
$\square 85$
$\square 86$
$\square 87$
$\square 87$

9. El tiempo que dedica la fomilia diaria ( 1 hora) y semanalmente (algunas horas); Ud. 10 destina:
Regularmente
$\square 82$
$\square 83$
$\square 84$
$\square 85$
$\square 86$
$\square 85$
$\square 86$
$\square 87$
Ocasionalmente
$\square 82$
$\square 82$
므8 83
묘84
$\square 85$
ㅁ 86
$\square 87$
..........
$\square 82$
$\square 83$
$\square 84$
$\square 85$
$\square$
$\square 87$
$\square 87$

II DEL EQUILIBRIO EN LOS ENFOQUES DE SU MINISTERIO

1. Aspecto Evangelización

a) La inversión que Ud. hace de los recursos materiales y humanos que dispone para la etaga de la siembra es:
Muy Buena
$\square 82$
七 83
TII 84
$\square 85$
디은
$\square 87$
Buena
182
디 83
드 84
됴 85
ㄷ] 86
디 87
Conviene mejorar $[82$
됴 83
다 84
C) 85
$\square 86$
$\square 87$

b) El número de estudios biblicos que Ud. da por semana (sugerencia:20) es:
Muy Buénos
됴 82
$\square 83$
드 84
$\square 85$
$\square 86$
$\square 87$
Bueno
$\square 82$
$\square 83$
$\square 84$
$\square 85$
$\square 86$
$\square 87$
Conviene aumentar $\square 82$
1783
$\square 85 \square 86$
$\square 87$

c) E1 tiempo que Ud. destina, el número de sus campañas ( 2 por año) y 105 frutos que por la gracia de Dios cosecha son: 
$\begin{array}{lllllll}\text { Muy Buenos } & \square 82 & \square 83 & \square 84 & \square 85 & \square 86 & \square 87 \\ \text { Buenos } & \square 82 & \square 83 & \square 84 & \square 85 & \square 86 & \square 87 \\ \text { Ineuficientes } & \square 82 & \square 83 & \square 84 & \square 85 & \square 86 & \square 87\end{array}$

d) Su equipo de instructores bíblicos (sugerencia: integrado por el 6\% de su feligresía) es:

$\begin{array}{lllllll}\text { Muy Bueno } & 082 & 083 & 1.14 & 085 & \square 86 & 087 \\ \text { Bueno } & \square 82 & \square 83 & \square 84 & 085 & \square 86 & \square 87 \\ \text { Insuficiente } & 0.2 & 083 & 084 & \square 85 & \square 86 & \square 87 \\ \text { Notiene } & \square 82 & 083 & \square 84 & 085 & 086 & \square 87\end{array}$

e) Su estuiio e investigeción respecto la evangelización en fuentes autorizadas es:

$\begin{array}{lrrrrrr}\text { Reguler } & \square 82 & \square 83 & \square 84 & \square 85 & \square 86 & \square 87 \\ \text { Ocasional } & \square 82 & \square 83 & \square 84 & \square 85 & \square 86 & \square 87 \\ \text { Nunce } & \square 82 & \square 83 & \square 84 & \square 85 & \square 86 & \square 87 \\ \text { iQué libro leyó?..... } & \ldots \ldots & \ldots \ldots & \ldots \ldots & \ldots \ldots & \ldots \ldots\end{array}$

\section{Aspecto Pastoral}

a) El número de visitas pastorales que Ud. hace por semana (sugerencia:20), es:

$\begin{array}{lllllll}\text { Muy Bueno (20) } & 082 & 083 & 084 & 085 & 086 & 087\end{array}$

$\begin{array}{lllllll}\text { Bueno (15) } & 082 & \square 83 & 084 & 085 & 086 & \square 87\end{array}$

Conviene aumentar $082 \quad \square 83 \quad \square 84 \quad \square 85 \quad 086 \quad \square 8$ ?

b) La forma como su distrito tiene montada la Operacion Rescate por Unidades Evangelizadoras, es:

$\begin{array}{lllllll}\text { Nuy Buena } & \square 82 & \square 83 & \square 84 & \square 85 & \square 86 & \square 87 \\ \text { Buena } & \square 82 & \square 83 & \square 84 & \square 85 & \square 86 & \square 87 \\ \text { No opera } & \square 82 & \square 83 & \square 84 & \square 85 & \square 86 & \square 87\end{array}$

c) Su fichero de visitas pastorales está:
Al dia
प 82
[ 83
ก] 84
084
085
๑ 86
$\square 86$
口87
Atrasado
082
D 83
1] 84 प 85
口 86
087
No tiene.
083
187

d) En su econsejomiento pastoral Ud. ce considera:
Acertado
082
ㅁ.3
0.82
ㅁ. 3
ㅁ 84
$\square 85$
$\square 8.4 \square 85 \quad \square 86$
口 86
ㅇㄱ
Rehúye
$\square 82$
प 83
$\square 84$
$\square 86$
ㅁ?
․ 37

e) Su estudio e investigación y consulta en otras fuentes autorizadas sobre esta especialicac es:

Regular

Ocasional

$\square \div 2$

$\square: 2$

083

$\square 84$

083

D 84

$\square .85$

口 85

$\square 85 \quad \square 86$

$\square 84$

ㅁ 85

口86

ㅁ. 87

Nunce

口 22

ㅁ 83

$\ldots \ldots \ldots$

L. 8.7

¿Qué libro leyó?....

3. Aspecto Formativo

a) La enseñanza es una tarea vital para el minjstro. Quien no forma se deforma, y el que instruye a otros se multiplica. El programa que Ud. 
tiene para preparar monitores, instructores biblicos, predicadores, maestros de Escuela Sabática, es:

$\begin{array}{lllllll}\text { Muy Bueno } & \square 82 & \square 83 & \square 84 & \square 85 & \square 86 & \square 87 \\ \text { Bueno } & \square 82 & \square 83 & \square 84 & \square 85 & \square 86 & \square 87 \\ \text { Insuficiente } & \square 82 & \square 83 & \square 84 & \square 85 & \square 86 & 1 \\ \text { No tiene } & \square 32 & \square 83 & \square 84 & \square 85 & \square 86 & \square 87\end{array}$

b) Lleva a cabo en su distrito la Jornada Trimestral de Capacitación, según las pautas del programa Penetreción:
Sí
082
$083 \quad \square 84$
$\square 85$
$\square 85$
$\square 86$
$\square 86$
085
0.86
$\square 87$
$\square 83 \quad \square 8.4$
ㅁ 87
Otros
प. 82

084

c) Los resultados que logra con est

e plan a Ud. 10 dejan:
Muy feliz
$\square 82$
082
ㅁ 83
$\square 84$
$\square 84$
$\square 84$
마 85
085
$\square 86$
$\square 86$
ㅁ 87
Preocupado
$\square 82$
083
$\square 85 \square 86$
ㅁ 87
D 87

d) Su estudio e investigación en el campo de la multiplicación y la didáctica, Ud. lo lleva a cabo en forma:
Regular
口:2
$\begin{array}{ll}\square 83 & \square 84 \\ 083 & \square 84\end{array}$
085
ㅁ.5
087
Ocasiona 1
082
$083 \quad \square 84$
085
08.6
ㅁ.86
$\begin{array}{ll}085 & 086 \\ 085 & 086\end{array}$
087
Nunca 082
$\square 83 \quad \square 84$
085
087
087
¿Qué libro leyó? $0 \$ 2$
$\square 87$

083 D84

\section{RESPECTO A LA ADMINISTRACION POR PRESENCIA}

1. Escuela

a) Tiene un plan regular paia visitar la escuela a lo menos dos vecis por semena:
Si
[] 82
1] 83
084
ㅁ 85
ㅁ 86
087
No
082
व 8304
D 85
$\square 86$
087
Otros
082
口.3 प24
$\square 85 \square 86$
ㅁ?

b) Considera Ud. que esas visitas son provechosas para la escuela y sus profesores:
Sí
No
08,2
082
083
083
$\square 84$
여
085
口 86
1] 86
$\square 87$
Otros
082
083
口 84
口 85
口 86
087
ㅇ 87

c) Participa Ud. en los programas de la escuela, las reuniones del Centro de Padres y la Junta Escolar:
$S i$
ㅁ. 82
$\square 83$
084
모
ㅁ 86
口 86
व 87
No
1082
0.3
083
084
0.95
口 86
08.7
[. 85
087 
2. Tesoreria

Analiza con su tesorero el libro de iclesia a lo menos una vez for mes:

$\begin{array}{lllllll}\text { Si } & \square 82 & \square 83 & \square 84 & \square 85 & \square 85 & \square 8 ? \\ \text { No } & \square 82 & \square 83 & \square 84 & \square 85 & \square 86 & \square 8 ? \\ \text { Tros } & \square 82 & \square 3 & \square \& 4 & \square 185 & \square 86 & \square 8 ?\end{array}$

3. Reuniones

a) Asicte y narticipa regularmente del Consejo de Maestros ce la Escuela Sabática en la j.glesio del distrito a la cual visita:
Siempre
$\square \leqslant 2$
$\square 83$
ए?
प] 85
$T] 86$
ㄷ?
Ocasionalmente
$\square ? 2$
$\square 93$
$\pi 84$
[15
口 86
므?
Nunce
ㄷ․2
口.8
प65. 5835
ㄷ․ 87

b) Asiste y participa regularmente de todo el programa de la Escuela Sabá tics en lo iglesia que Ud, visita:
Siempre
$\square 82$
므요 $83 \quad \square 84$
$\begin{array}{ll}\square 5 & \square 86 \\ t 85 & \square 86\end{array}$
$\square 87$
Ocesionelmente
모2
$\square 83 \quad \square 84$
됴 85
$\square 85$
ㄷ87
Nunce
$\square 82$
Den 당
ㅁ 87

c) Se abstiene de celebrar sesiones de la Junta Directiva de la iglesia mientras se están celebrando reuniones regulares de la misma:

$\begin{array}{lllllll}\text { Si } & \square 82 & \square 83 & \square 84 & \square 85 & \square 86 & \square 87 \\ \text { No } & \square 82 & \square 83 & \square 84 & \square 85 & \square 86 & \Gamma 87 \\ \text { A veces } & \square 82 & \square 83 & {[84} & {[85} & \square 86 & \square 87\end{array}$

\section{ASPECTO EVALUACION}

1. La Junta de la IElesia evalúa trimestralmente los informes de cada departamento:

$\begin{array}{lllllll}\text { Siempre } & \square 82 & \square 83 & \square 84 & \square 85 & \square 86 & \square 87 \\ \text { Ocasionalmente } & \square 82 & \square 83 & \square 84 & \square 85 & \square 86 & \square 87 \\ \text { Nunca } & \square 82 & \square 83 & \square 84 & \square 85 & \square 86 & \square 87\end{array}$

2. Envia sus informes ya evaluados por la iglesia, a la asociación, y una nota al Presidente con sus observaciones sobre los mismos, ya que Ud. es el representante de la administración en el distrito:
Regularmente
Ocasionalmente
$\square 82$
1723
[1] 83
口. 4
$\square 85$
느 85
口 85
$\square 86$
$\square 86$
$\square 86$
$\square 8.7$
디요 82
ㄷ3 पㅇㄴ
ㅁ.87
口8?

V SOBRE LAS DOCTRINAS

1. Su conocimiento sobre las doctrinas peculiares y fundamentales de nuestra iflesia, es:
Muy Eueno
$\square ?$ ?
Dי3
$\square: 4$
$\square 65$
$\square 85$
D.6
$\square: 7$
Bueno
$\square ?$ ?
$[183$
도 84
L185
[] 86 ;
$\square \varepsilon ?$
Conviene mejorar $\square \& 2$
[1) 85
口 37 
2. Su capacidad pare exponerlas es:
Muy Buena
$\square, 2$
a 83
08.14
085
$\square 85$
087
Buena
082
083
0 84
1] 85
086
$\square 87$
Conviene mejorar $\square \& 2$
083
084
085
口 86
$\square 8 ?$

3. Su habilided para deferererlas es:
Muy Buena
$\square 82$
0.83
08.4
$\square 85$
ㅁ 86
$\square 86$
087
Buena
$\square 82$
$\square 83$
084
D. 85
$0 \leqslant 3$
व 84
$\square 85$
व 86
087
[0.7

4. Su conocimiento sobre las doctrinas suetentadas por otros grupos relifiosos, es:
Muy Bueno
$\square 82$
$[082$
083
083
ㅁ 84
D 84
085
083
084
085
प 25
C.86
086
प 86
$\square 87$
$\square 87$
Conviene mejorar 882

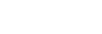

\section{SOBRE LAS PROFECIAS}

1. Su conocimiento sobre las profecies que nos distinguen como movimiento, es:
Muy Bueno
$\square 82$
ㅁ 82
083
084
$083 \quad 084$
$083 \quad \square 84$
035
प. 25
085
$\square 86$
ㅁ. 86
$\square \& 6$
$\square 87$
Conviene mejorar $\square 82$
087

2. Su capacidad para exponerlas es:
Muy Buena
$\square: 2$
0.33
$\square 84_{4}$
085
085
0.83
083
$\square 84$
085
036
D 86
Conviene mejorar $\square 82$
084
ㅁ86
087
$\square 87$
ㅁ] 67

3. Su habilicad para defenderlas es:
Muy Buena
Buena
$\square 82$
082
083
(084
085
$\square 85$
$\square 83$
083
D 84
085
085
D 86
086
口 87
1. 87 ?
D 37

\section{SORRE LOS MANUALES}

1. Su conocimiento y aplicación del Manuol de la Jglesta a la arministración de su distrito es:
Muy Bueno
Bueno
प 82
ㅁ 8.2
083
$\square \& 3$
$\square 84$
84
$\square 85$
085
$\square 86$
D 86
$\square 87$
$\square 85$
प 86
087
口 8 ?

2. Su conocimiento y aplicación del Manual ae la Escuela Sabitica a la direc ción de la misma en su distrito es:
Muy Bueno
082
Bueno
$\square 8.2$
$\square 83$
$0 \varepsilon 4$
$0.83 \quad 0.4$
085
025

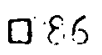
[0] 85
087
Conviene mejorar $\square 82$
प 83
C. 84
08.5
D) 85
0.87 
3. Su conocimiento y aplicación del Manual de Asistencia Social al programa de las Dorcas en su distrito es:
Muy Bueno
ㅁ. 92
$\square 83 \quad \square 84$
[) $? 2$
$0 ? 3$
[0.4
$0 \% 5$
$0=6$
ㅁ 87
Conviene mejorer $\square 82$
[]. 23
[] 84
0.5
$\square .36$
ㅁ 87
․ 85
026
口 87

4. Su conocimiento y ap!jcación del Reglamento de 5. . . ón ten la administración de su escuela es:
My Bieno
[1] 82
Bueno
0.5
$\square 23$
103
$\square \times 4$
[1] 85
a 86
[) 84
(]) 8
प 86
[? $? 27$
Conviene mejorer.
II? ?
묘
D?
[.] 5
ㅁ 85
$\square \div ?$
0.87

VIII DE IA INTEGRACION

1. Su Consejo Distrital está formado:
Si
a $\because 2$
0.3
[ᄆ ? 4
प 85
ㅁ 86
$\square: 7$
No
ㅁ2
प] $84 \square 5$
0. 8.6
$\square 67$

2. El Consejo Distritel - pastores - colportores y maetros - personal de la salud - se reúne:

Una vez al mes

Cada dos semanas

(] 82

082

083

083

ப் 84

口 84

무 3

$\square 84$

ㅁ 85

085

प 83 प 84

085

口 82

Nunca

$\square 82$

1083

$\square 84$

085

. 85

ㅁ. 86

[. 86

[ ] 87

Otros

182

18

086

口 86

086

D. 87

$05 ?$

D.87

ㅁ 87

IX EL MINISTERIO Y SU DIGNIDAD

1. Su voz, pronunciación, vocabulario y ortografia representin a su ministerio en forma:

Muy Buena

Buena

$\square 82$

$\square 82$

$\square 83$

$\square 83$

084

085

1. 85

0] 84

D 83

[1 84

ㄱ 85

0.6
0.6
065

[] 87

Conviene mejorar [] 82

2. Su troto, gestos y ademanes, jo caracterizon a Ud, como un mintetro en forna:
Huy Buena
D.2
Buena
$\square 82$
$\square: 3$
D 83
084
ㅁ. 85
प 85
D. 86
[] 6
0.86
D? ? ?
D 83
D?
D. 8.5
D? 9
Conviene mejorar $\square \& 2$

3. Su vestimenta y objetos personales, la precentación de su vivienda (y de su familia), oficina, sala pastoral, lo identifican a Ud. como un minjstro, en forma:
Muy Buena
02
Ruena.
$0 \div 2$
Conviene mejorar $0 \div 2$
083
$0=3$
024
095
(1) 85
0. 86
П?:?
D 94
D. 5
085
056
口.?
$\square=$ ?

4. Ln eperiencio personal suya y la de al fomiliz es a so gre pare vi. tiene: Nucha importancia $\square \geqslant ?$ Algura importan: $30=2$ No hatia perate. $\square=2$
口?
$0 \div 3$
D)
0) 5
[1) 54
口.
. 5
D. 63
[.] 0.4

口

0

Q $: ?$

D.

U? 
5. Si Ud. tiene un lanual de Ortoeraria, Diccionario y Diccionario de Sinónimos, los consulte:
Con frecuencia
प. 2
Pocas veces
082
$\square 83$
प?
Nunces
0.2
10.3
[]$\leqslant 2$
$0 \div 4$
$\square=5$
$0 \times 5$
D?
D 05
D.4
口 $\div 5$
0.6
$0 \div 6$
086
$\square: 6$
$\square \div 7$
[] 9.7
1] 23
[186
D? $?$
1]?

6. Su esposo, algura persona colificaca o mediante una prabodorn, ia. se ayudo pera superar las deficiencias que pudiera teret en el crmo de le vredicación:
Si
1] 22
No
$\square 82$
0.3
1.] 24
1] 85
1] 66
口27
No habia pensado $\square 82$
$\square: 3$
1.] 84
0 05
[1] 65
10?
[.] 84
0.5
口: 6
$08 ?$

$X$ DE IA FROGRAMACION

1. El programa de la iglesia es la suma de los programas de caca cepartamento. Si éstos responcien satiefactoriamente al Qué, Cómo, Cúndo. Dónde y Con quién, podré calificarse adecuado. El programa de sus defartamertos puede calificarse entonces como:
Muy Bueno
ㅁ. 52
[1 82
0.3
[. 84
$\square 85$
0.5
08.6
[] $: 7$
Sueno
口:3
ㅁ.84
085
0 86
[1 87
Conviene mejorar 0.2
[1 84
D. 86
[0] $: ?$

2. Le programación ce sus Campañas de Evangelización es:
Yuy Buena
प? 8
Buena
1.?
0.83
1] 84
口 85
(1) 85
ㄷ.6
0.3
口 84
$\square 85$
1].6
1] 83
(]) 84
D. 25
(]) 8.6
口.6
087
[1)?
0.3
024
D??
ㅁ. 6

3. Su echeción a le prograrieción personal es:
Reguiar
[] 92
Irregular
ㅁ. 12
प] 83
D 84
$\square 85$
[]:6
1]??
Conviene mejorar $[782$
$[1.83$
[] $: 4$
1] 85
[].86
[3]?
0.86
0.3

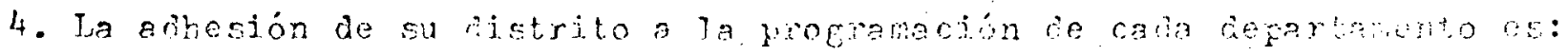
Buy Buena
1. 82
Buena
[1]?
$\square .3$
1] 4
(1) 25
[1. 3
[] 04
1] 85
1] 26
is?
Conviene mejorar $\square$ ?
口??
D. 4
1] 5
19 86
(1) 2
[.] 8 ?

XI VARIOS

Su conocimiento respecto a los acontecimientos mundinles es:
Muy Eueno
[?? ?
[1] $? 2$
$\mathrm{C}^{\circ} \times 3$
$0=4$
D? 8
[] $: 4$
口.
[] 06
$\square \subset F$.
17??
Escaso
[] $\approx 2$ ?
[ ] $\div 3$
L] $\div 4$
口:
$\square=5$
[ ] $\therefore ?$ 
XII DE IAS FINANYAS

Las finanzas es un acunto en el cual participa la famjla en la planificación:
Regularmente
Irregularmente
$\square .2$
$\square \times 2$
0.6
a. 3
$0 \div 3$
$\square^{24}$
口) 5
口?
02 ?
$\because$ inca
a. 3
084
व.
1] 86
[.] 8 ?

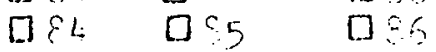
口.?

\section{DE IA AUTOCRIMICA}

1. Curnce elpuien lo critica Ura:
Se ebate
口??
093
0.5
口?
口?
086
$08 ?$
Se irrita $1 ? 2$
1] 3
024
1085
086
$1] 87$
Evalúa la observ. 02
口 84
ㅁ. 85
$\square 86$
[] 87
T'iende a reaccionar
con agresivifiad 0.2
Q.3 084 प85. 86
87

2. En cuanto a las posiciones que cada uno debe tomar en la vida, Uà. se considera que:
- Lee bepta $\quad 0 ?$
083
$\square \&$ :
$\square \leqslant 5$
$\square \& 5$
$\square 87$
Prefiere mantener
la neutralidad $\square 82$
$\square 33$
$\square 84$
$\square 85$
$\square 86$
$\square 87$
- Las modijica por las conveniencias 82
- Frefiere no dirlas.
a conocer
[] 82
$083 \quad 084 \quad 085 \quad 085$
$\square 87$

3. Como ministro en el desempeño de sus funciones Ud. se considera:

\begin{tabular}{|c|c|c|c|c|c|c|}
\hline $\begin{array}{l}\text { Reglizado } \\
\text { Satisfecho con }\end{array}$ & 082 & $\square 83$ & [0 24 & 085 & 口 $8: 6$ & 087 \\
\hline sus logros & $\square 82$ & 083 & [1] 84 & 085 & 086 & $\square 87$ \\
\hline Preocupedo & $\square 82$ & 083 & 084 & 085 & 86 & $\square 87$ \\
\hline $\begin{array}{l}\text { Fiensa a veces en } \\
\text { cambiar de linea }\end{array}$ & $\square 82$ & $\square, 3$ & $\square 84$ & 085 & 086 & a \\
\hline $\begin{array}{l}\text { Fienea a veces en } \\
\text { car otro trabejol }\end{array}$ & bus $8 \frac{5}{2}$ & 083 & 084 & 085 & 006 & D. \\
\hline
\end{tabular}

XIV CON RELACION A IA PAOBJA

1. Vi. siente que la cominicación con su espose es:
Nuy Buena
Duena.
[0 82
$0 ? 2$
10 83
084
025
[0.86
087
Irregu? ar
$\square \leqslant 2$
10.3
ㄱ. 24
085
083
$0=4$
D 85
Es poca
$\square .83$
084
[0.5
0. 085
086
0.8?
$\square 8.6$
0 87
No hay
प 82
․ 8.3
086
प8 7
C. 86
ㅁ.?

2. Vè. siente que la comianiceción con su esposo es:
Mu Buens
$0 ?$
$\begin{array}{rl}2 & 3 \\ 5 & 3\end{array}$
$0=11$
D] $0=5$

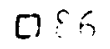
$0 ;=7$
Dueno

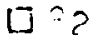
$[i=3$
[?
a?
$5:=7$
Irregular
$0: 3$
$0=?$
ㅁ. $\%$.
[?
a $=5$
ㄷ?
Er ince
[ $: 2$
D.3
$[: 4 \quad[:=5$
$E=5$
556
[ᄃ: $: 7$
tio hey
두ó
[5] 
3. Indique el tiempo de actividades que llevan a cabo juntos como pareja:

4. El tiempo que su expnan redica a los hijos, Ud. lo considera:

$\begin{array}{lllllll}\text { Suficiente } & \square 82 & \square 83 & \square 84 & \square 85 & \square 86 & \square 87 \\ \text { Irregular } & \square 82 & \square 83 & \square 84 & \square 85 & \square 86 & \square 87 \\ \text { Escaso } & \square 82 & \square 83 & \square 84 & \square 85 & \square 86 & \square 87 \\ \text { Nada } & \square 82 & \square 83 & \square 84 & \square 85 & \square 86 & \square 87\end{array}$

5. El tiempo que su esposo le dedics a Ud. lo consicha:

$\begin{array}{lllllll}\text { Suficiente } & \square 82 & \square 83 & \square 84 & \square 85 & \square 86 & \square 87 \\ \text { Irregular } & \square 82 & \square 83 & \square 84 & \square 85 & \square 86 & \square 87 \\ \text { Escaso } & \square 82 & \square 83 & \square 84 & \square 85 & \square 86 & \square 87 \\ \text { Nada } & \square 82 & \square 83 & \square 84 & \square 85 & \square 86 & \square 87\end{array}$

$t=t=t=t=t=t=t=t=t=t=$ 
PERSONAL EVALUATION GUIDE FOR THE DISTRICT WORKER

Name

District

Conference

Dates of Evaluation: Name of Participating Conference President

1982

1983

1984

1985

1986

1987

I. A WELL-BALANCED PROGRAM

1. Your dedication to an active daily program is:

Very good [ ] 82 [ ] 83 [ ] 84 [ ] 85 [ ] 86 . [ ] 87

Good [ ] 82 [ ] 83 [ ] 84 [ [ ] 85 [ [ ] 86 [ ] 87

Must improve [ ] 82 [ ] 83 [ ] 84 [ ] 85 [ ] 86 [ ] 87

[ ] 82 [ ] 83 [ ] 84 [ [ ] 85 [ ] 86 [ ] 87

2. Your dedication to the yearly program of the district is:

$\begin{array}{llllllllllllll}\text { Very good [ ] } 82 & \text { [ ] } 83 & \text { [ ] } 84 & \text { [ ] } 85 & \text { [ ] } 86 & \text { [ ] } 87\end{array}$

Good [ ] 82 [ ] 83 [ ] 84 [ ] 85 [ ] 86 [ ] 87

Must improve : [ ] 82. [ ] 83 [ ] 84 [ [ ] 85 [ ] 86 [ ] 87

[.] 82 [ ] 83 [ ] 84 [ ] 85 [ ] 86 [ ] 87

3. Your daily personal devotions is. (suggested: $30 \mathrm{~min}$ ):

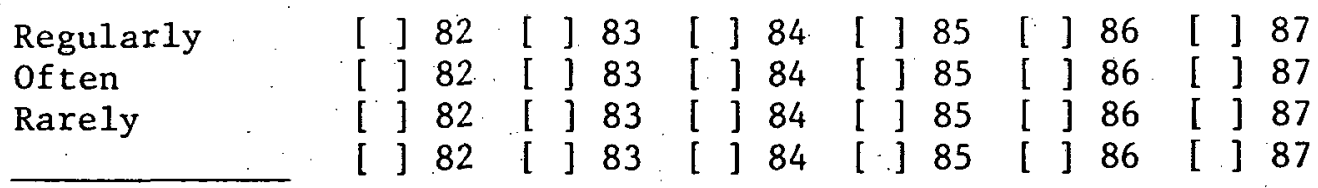


4. Morning and evening family worship:

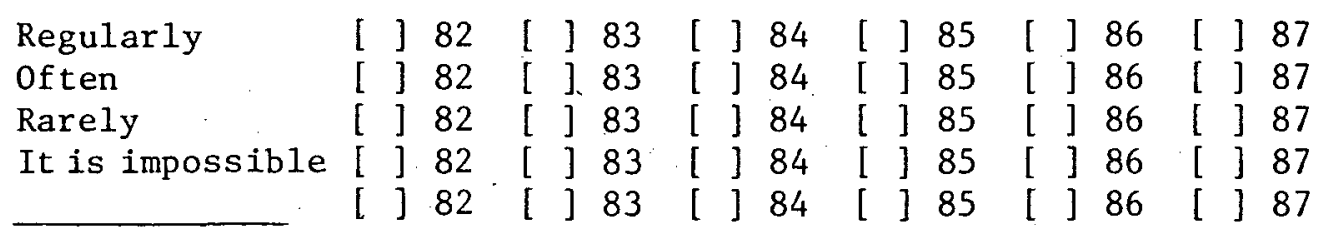

5. Do you spend somertime daily (suggested: $1.5 \mathrm{hrs}$ ) to study and research?

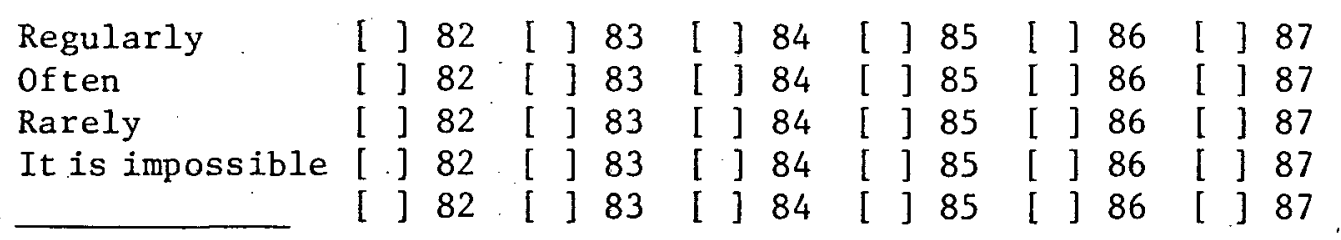

6. Do you spend some time daily (suggested: $30 \mathrm{~min}$ ) to get acquainted with church, Sabbath school, community service, and educational policies (studying manuals, etc.)?

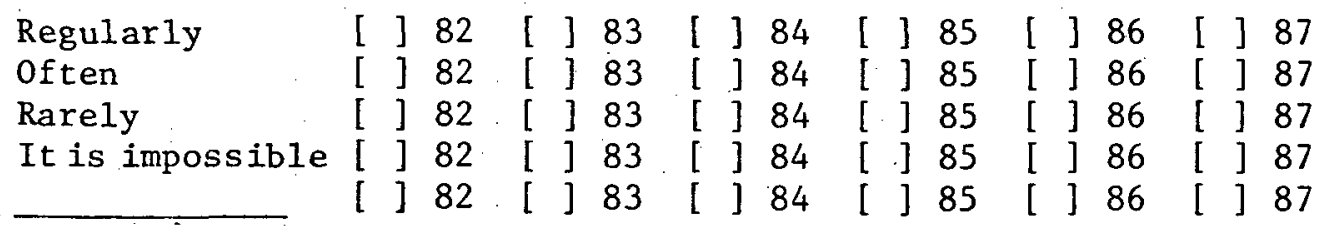

7. Do you spend some time daily (suggested: $30 \mathrm{~min}$. ) to attend to administrative matters such as mail, financial matters, reports, buying supplies, keeping the congregation informed on your activities, etc.?

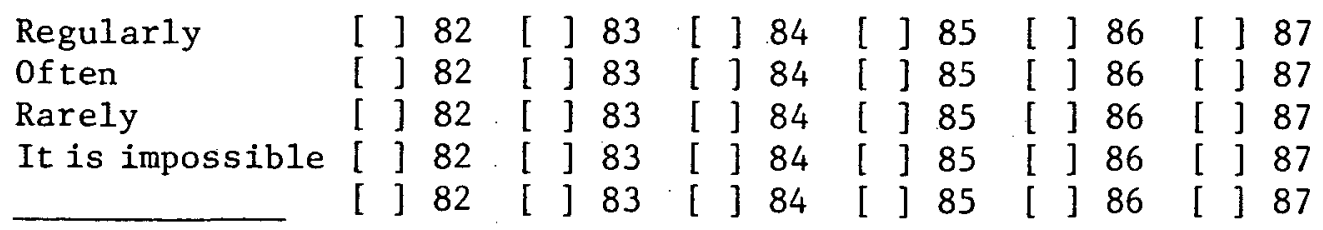

8. Do you excercise physically daily? (Does your wife join you?)

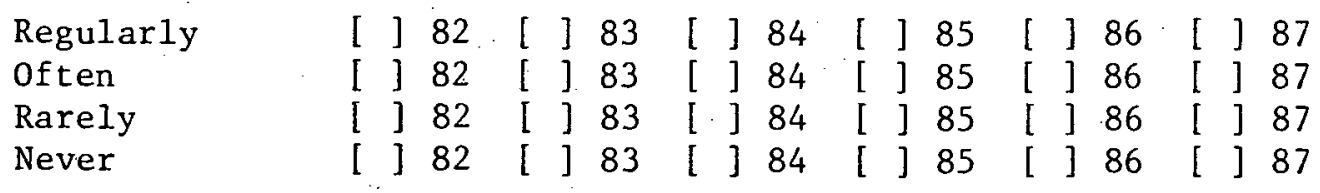

9. Do you set aside time every day for your family ( 1 hour) and weekly (several hours)?

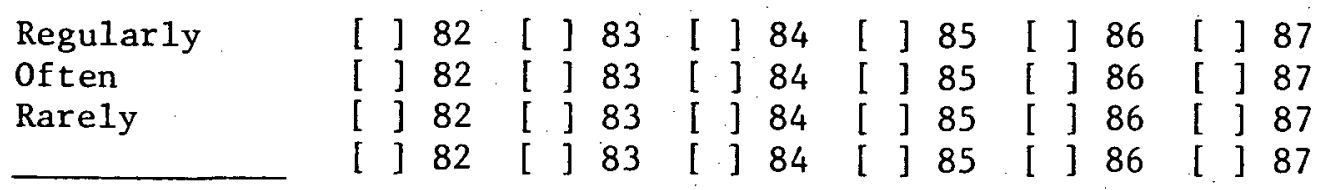




\section{A BALANCED PROGRAM OF MINISTRY}

1. Evangelism

a. Your use of available human and material resources in the sowing stage is:

Very good : [ ] 82 [ ] 83 [ ] 84 [ ] 85 [ ] 86 [ ] 87

Good [] 82 [ ] 83 [ ] 84 [ ] 85 [ ] 86 [ ] 87

Must improve [] 82 [ ] 83 [ ] 84 [ ] 85 [ ] 86 [ ] 87

b. The number of Bible studies you give weekly (suggested: 20):

$\begin{array}{lllllllllllllllll}\text { Very good } & \text { [ ] } 82 & \text { [ ] } & 83 & \text { [ ] } & 84 & \text { [ ] } 85 & \text { [ ] } & 86 & \text { [ ] } 87\end{array}$ $\begin{array}{lllllllll}\text { Good [ ] } 82 & \text { [ ] } 83 & \text { [ ] } 84 & \text { [ ] } 85 & \text { [ ] } 86 & \text { [ ] } 87\end{array}$ Must improve [ ] 82 [ ] 83 [ ] 84 [ ] 85 [ ] 86 [ ] 87

c. Time you dedicate to public evangelism (2 each year) and the fruit that by God's grace are realized:

$\begin{array}{llllllllllllll}\text { Very good [ ] } 82 & \text { [ ] } 83 & \text { [ ] } 84 & \text { [ ] } 85 & \text { [ ] } 86 & \text { [ ] } 87\end{array}$ Good [ ] 82 [ ] 83 [ ] 84 [ ] 85 [ ] 86 [ ] 87 Insufficient [ ] 82 [ ] 83 [ ] 84 [ ] 85 [ ] 86 [ ] 87

d. Your team of Bible instructors (suggested: $6 \%$ of your parish):

$\begin{array}{lllllllllllll}\text { Very good } & \text { [ ] } 82 & \text { [ ] } 83 & \text { [ ] } 84 & \text { [ ] } 85 & \text { [ ] } 86 & \text { [ ] } 87\end{array}$ $\begin{array}{llllllllll}\text { Good [ ] } 82 & \text { [ ] } 83 & \text { [ ] } 84 & \text { [ ] } 85 & \text { [ ] } 86 & \text { [ ] } 87\end{array}$ Insufficient [ ] 82 [ ] 83 [ ] 84 [ ] 85 [ ] 86 [ ] 87 Do not have any [ ] 82 [ ] ] 83 [ ] 84 : [ ] 85 [ ] 86 [ ] 87

e. Your study and research dealing with evangelism (from authoratative sources):

$\begin{array}{llllllllllllllll}\text { Regularly } & \text { [ ] } 82 & \text { [ ] } 83 & \text { [ ] } 84 & \text { [ ] } 85 & \text { [ ] } 86 & \text { [ ] } 87\end{array}$ Often [ ] 82 [ ] 83 [ ] 84 [ ] 85 [ ] 86 [ ] 87 Never [.] 82 . [ ] 83 [ [ ] 84 [ ] 85 [ ] 86 [ ] 87

Which book?

2. Pastoral duties

a. Number of pastoral calls you make weekly (suggested: 20):

Very good (20) [ ] 82 [ ] 83 . [ ] 84 [ ] 85 [ ] 86 [ ] 87 Good (15) [ ] 82 [ ] 83 [ ] 84 [ ] 85 [ ] 86 [ ] 87 Must improve [ ] 82 [ ] 83 [ ] 84 [ ] 85 [ [ ] 86 [ ] 87 b. How the "Operation Rescue" is proceding in your district? $\begin{array}{lllllllllllllllll}\text { Very good } & {[} & 82 & \text { [ ] } 83 & \text { [ ] } 84 & \text { [ ] } 85 & \text { [ ] } 86 & \text { [ ] } 87\end{array}$ $\begin{array}{llllllllll}\text { Good [ ] } 82 & \text { [ ] } 83 & \text { [ ] } 84 & \text { [ ] } 85 & \text { [ ] } 86 & \text { [ ] } 87\end{array}$ Not using it [ ] 82 [ ] 83 [ ] 84 [ ] 85 [ ] 86 [ ] 87 
c. Your file of pastoral calls is:

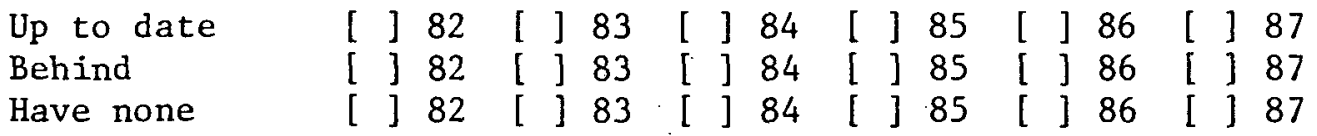

d. How do you consider your pastoral counseling ministry?

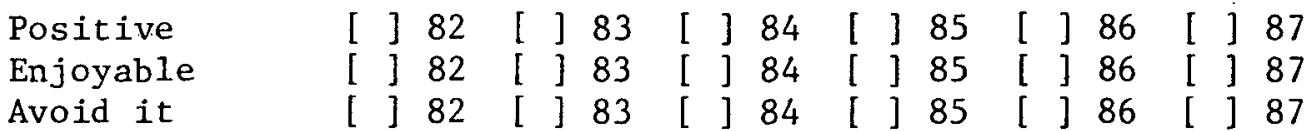

e. Your study and research on counseling (from authoratative sources) is:

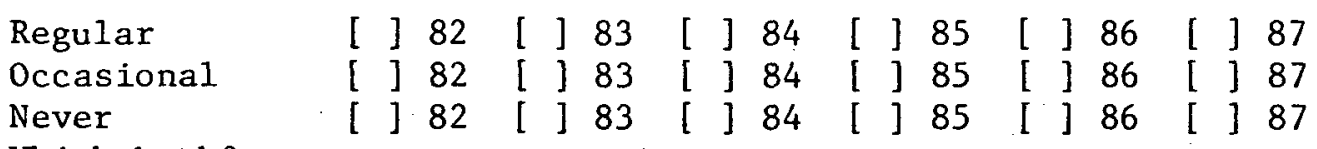

Which book?

3. The training role

a. Teaching others is an important part of the minister's work. He who does not teach others destroys his own knowledge, while he who trains others multiplies himself. Your program for preparing trainees, Bible instructors, lay preachers, Sabbath school teachers, is:

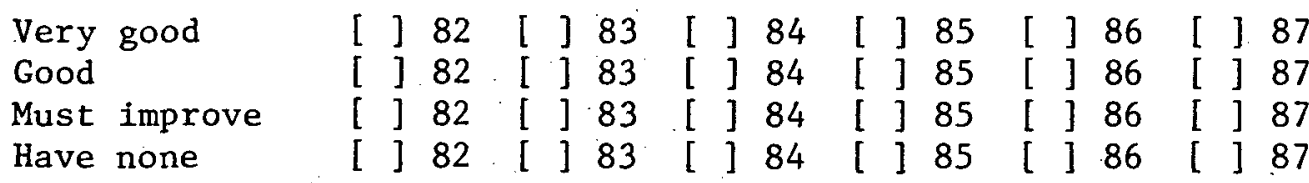

b. Does your district frulfill the "Jornada Trimestral de Capacitacion" according to the guidelines of "Operation Penetration"?

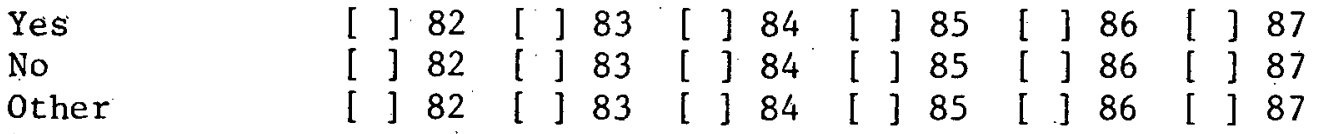

c. How do you feel about the results of this plan in your district?

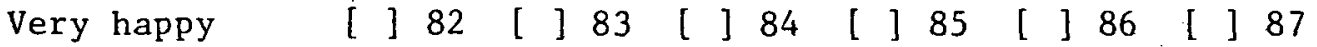

Satisfied [ ] 82 [ ] 83 [ ] 84 [ ] 85 [ ] 86 [ ] 87

Concerned [ [ ] 82 [ ] 83 [ ] 84 [ ] 85 [ ] 86 [ ] 87

d. Your study and research in the field of teaching and training others is:

Regular [ ] 82 [ ] 83 [ ] 84 [ ] 85 [ ] 86 [ ] 87

Occasiona1 [ ] 82 [ [ ] 83 [ ] 84 [ ] 85 [ ] 86 [ ] 87

When I need to [ ] 82 [ ] 83 [ ] 84 [ ] 85 [ ] 86 [ ] 87

Never [ ] 82 [ ] 83 [ ] 84 [ ] 85 [ ] 86 [ ] 87

Which book? 


\section{Administrative Role}

1. School

a. Do you have a regular plan to visit the school at least twice a week?

$\begin{array}{llllllllllllll}\text { Yes [ } 82 & \text { [ ] } 83 & \text { [ ] } 84 & \text { [ ] } 85 & \text { [ ] } 86 & \text { [ ] } 87\end{array}$

No [ ] 82 [ ] 83 [ ] 84 [ ] 85 [ ] 86 [ ] 87

Other [ ] 82 [ ] 83 [ ] 84 [ ] 85 [ ] 86 [ ] 87

b. Do you consider these visits useful to the teachers and the school?

$\begin{array}{lllllllllllllllll}\text { Yes } & \text { [ ] } 82 & \text { [ ] } 83 & \text { [ ] } 84 & \text { [ ] } 85 & \text { [ ] } 86 & \text { [ ] } 87\end{array}$

No [ ] 82 [ ] 83 [ ] 84 84 [ ] 85 [ ] 86 [ ] 87

Other [ ] 82 [ ] 83 [ ] 84 [ ] 85 [ ] 86 [ ] 87

c. Do you participate in the regular school programs, the Home and School meetings and the school board:

Yes [ ] 82 [ ] 83 [ ] 84 [ ] 85 [ ] 86 [ ] 87

No [ ] 82 [ ] 83 [ ] 84 [ ] 85 [ ] 86 [ ] 87

Other [ ] 82 [ ] 83 [ ] 84 [ 84 [ ] 85 [ ] 86 [ ] 87

2. Finances

Do you review the treasurer's books at least once a month?

Yes [ ] 82 [ ] 83 [ ] 84 [ ] 85 [ ] 86 [ ] 87

No [ [ ] 82 [ ] 83 [ ] 84 [ ] 85 [ ] 86 [ ] 87

Other [ ] 82 [ ] ] 83 [ ] 84 [ ] 85 [ ] 86 [ ] 87

3. Meetings

a. Do you regularly attend and participate in the Sabbath school teachers' class of the church in your district which you are visiting?

Always Occasionally [ ] 82 [ [ ] 83 [ ] 84 [ [ ] 85 [ ] 86 [ ] 87 Never

[ ] 82 [ [ ] 83 [ ] 84 [ ] 85 [ ] 86 [ ] 87

b. Do you regularly attend and participate in the Sabbath school program of the church in your district which you are visiting?

Always Occasionally Never

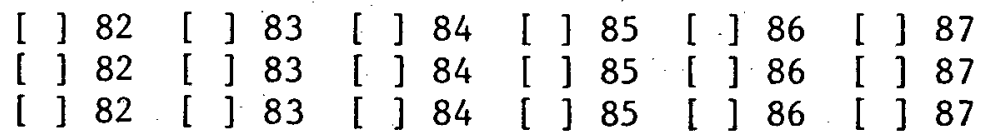


c. Do you avoid holding church board meetings at the same time Other regular church meetings are taking place?

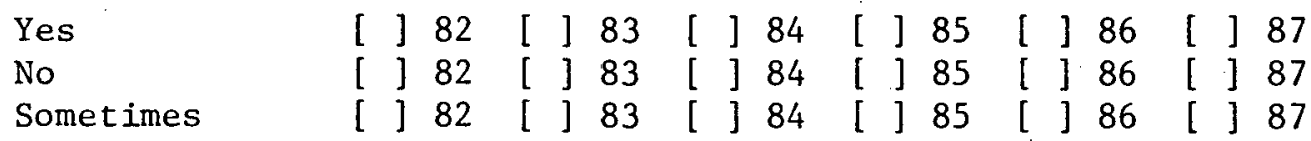

IV. Evaluation Program

1. Does the church board review the departmental reports each quarter?

Always [ ] 82 [ ] 83 [ ] 84 [ ] 85 [ ] 86 [ ] 87

Occasionally [ ] 82 [ ] 83 [ ] 84 [ ] 85 [ ] 86 [ ] 87

$\begin{array}{llllllllllllll}\text { Never } & \text { [ ] } 82 & \text { [ ] } 83 & \text { [ ] } 84 & \text { [ ] } 85 & \text { [ ] } 86 & \text { [ ] } 87\end{array}$

2. Do you send the church's already-evaluated reports to the conference with your observations, since you are the administrative representative of your district?

$\begin{array}{lllllllllllllllll}\text { Regularly ['] } 82 & \text { [ ] } 83 & \text { [ ] } 84 & \text { [ ] } 85 & \text { [ ] } 86 & \text { [ ] } 87\end{array}$

Occasionally [ ] 82 [ ] 83 .[ ] 84 [ [ ] 85 [ ] 86 [ ] 87

Never

[ ] 82 [ ] 83 [ ] 84 [ ] 85 [ ] 86 [ ] 87

V. Doctrines

1. Your knowledge of the fundamental and peculiar doctrines of the church is:

Very good [ ] 82 [ ] 83 [ ] 84 [ ] 85 [ ] 86 [ ] 87

Good [ ] 82 [ [ ] 83 [ [ ] 84 [ ] 85 [ ] 86 [ ] 87

Must improve [ ] 82 [ ] 83 [ ] 84 [ ] 85 [ ] 86 [ [ ] 87

2. Your ability to explain them is:

Very good [ ] 82 [ ] 83 [ ] 84 [ ] 85 [ ] ] 86 [ ] 87

Good [ ] 82 [ [ ] 83 [ ] 84 [ ] 85 [ ] 86 [ ] 87

Must improve [ ] 82 [ ] 83 [ ] 84 [ ] 85 [ ] 86 [ ] 87

3. Your ability to defend them is:

Very good [ ] 82 [ ] 83 [ ] 84 [ ] 85 [ ] 86 [ ] 87

Good [ ] 82 [ ] 83 [ ] 84 [ ] 85 [ ] 86 [ ] 87

Must improve [ ] 82 [ ] 83 [ [ ] 84 [ ] 85 [ ] 86 [ ] 87

4. Your knowledge of the doctrines of other religious groups is:

Very good . [ ] 82 [ ] 83 [ ] 84 [ ] 85 [ ] 86 [ ] 87

Good [ ] 82 [ ] 83 [ ] 84 [ ] 85 [ ] 86 [ ] 87

Must improve [ ] 82 [ ] 83 . [ ] 84 [ ] 85 [ ] 86 [ ] 87 
VI. Prophecies

1. Your knowledge of the prophecies that distinguish us as a movement is :

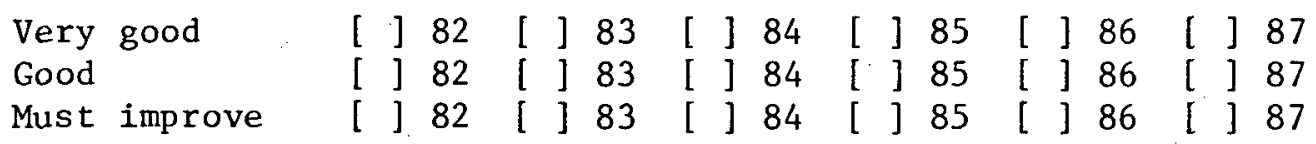

2. Your ability to explain them is:

$\begin{array}{lllllllllllllllll}\text { Very good } & \text { [.] } 82 & \text { [ ] } 83 & \text { [ ] } 84 & \text { [ ] } 85 & \text { [ ] } 86 & \text { [ ] } 87\end{array}$

Good [ ] 82 [ ] 83 [ ] 84 [ ] 85 [ ] 86 [ ] 87

Must improve [ [ ] 82 [ ] 83 [ ] 84 [ ] 85 [ ] 86 [ ] 87

3. Your ability to defend them is:

Very good [ ] 82 [ ] 83 [ ] 84 . [ ] 85 [ ] 86 [ ] 87

Good [ ] 82 [ ] 83 [ ] 84 [ ] 85 [ ] 86 [ ] 87

Must improve. [ ] 82 [ ] 83 [ ] 84 [ ] 85 [ [ ] 86 [ ]. 87

VII. Manuals

1. Your knowledge of and application of the Church Manual in the administration of your district is:

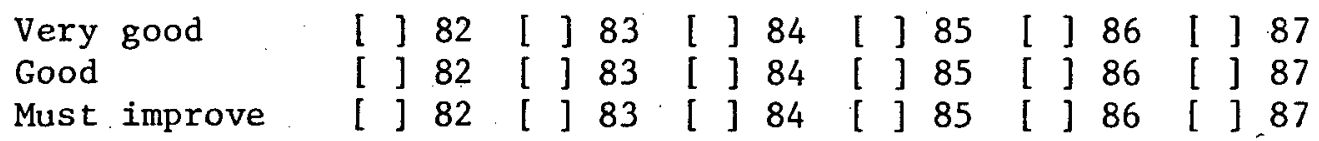

2. Your knowledge of and application of the Sabbath School Manual in the leadership of the same in your district is:

$\begin{array}{llllllllllllllllll}\text { Very good } & {[} & 82 & \text { [ ] } & 83 & \text { [ ] } & 84 & \text { [ ] } & 85 & \text { [ ] } & 86 & \text { [ ] } & 87 \\ \text { Good } & {[\text { ] }} & 82 & \text { [ ] } & 83 & \text { [ ] } & 84 & \text { [ ] } & 85 & \text { [ ] } & 86 & \text { [ ] } & 87 \\ \text { Must improve } & {[\text { [ ] }} & 82 & \text { [ ] } & 83 & \text { [ ] } & 84 & \text { [ ] } & 85 & \text { [ ] } & 86 & \text { [ ] } & 87\end{array}$

3. Your knowledge of and application of the Community. Services Manual in the Dorcas programs in your district is:

$\begin{array}{llllllllllllllllll} & \text { Very good [ ] } 82 & \text { [ ] } 83 & \text { [ ] } 84 & \text { [ ] } 85 & \text { [ ] } 86 & \text { [ ] } 87\end{array}$ Good [ ] 82 [ ] 83 [ ] 84 [ ] 85 [ ] 86 [ ] 87 Must improve [ ] 82 [ ] 83 [ ] 84 [ [ ] 85 [ ] 86 [ ] 87

4. Your knowledge of and application of the Educational Manual in the administration of your district is:

$\begin{array}{llllllllllllll}\text { Very good [ ] } 82 & \text { [ ] } 83 & \text { [ ] } 84 & \text { [ ] } 85 & \text { [ ] } 86 & \text { [ ] } 87\end{array}$

Good [ ] 82 [ [] 83 [ ] 84 [ ] 85 [ ] 86 [ ] 87

Must improve. [ ] 82 [ ] 83 [ ] 84 [ ] 85 [ ] 86 [ ] 87 


\section{District Integration}

1. Have you organized a District Council?

$\begin{array}{llllllllllllllll}\text { Yes } & \text { [ ] } 82 & \text { [ ] } 83 & \text { [ ] } 84 & \text { [ ] } 85 & \text { [ ] } 86 & \text { [ ] } 87\end{array}$ No [ ] 82 [ ] 83 [ ] 84 [ ] 85 [ ] 86 [ ] 87

2. How often does the District Council meet (pastors, colporteurs, teachers, medical personnel)?

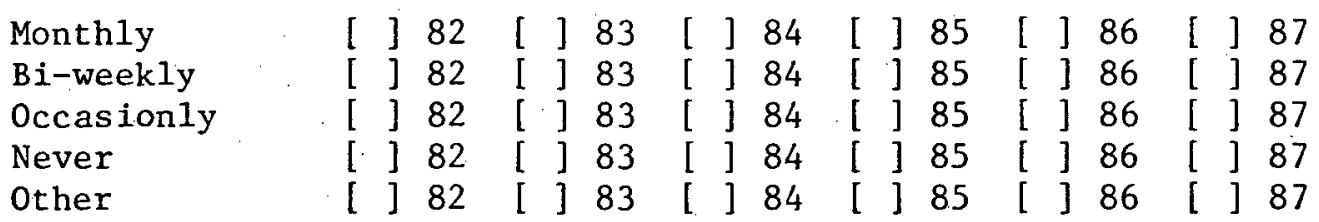

IX. The Appearance of the Minister

1. How does your voice, pronunciation, a vocabulary and spelling represent your ministry?

Very good [ ] 82 [ ] 83 [ ] 84 [ ] 85 [ ] 86 [ ] 87 Good [ ] 82 [ ] 83 [ ] 84 [ ] 85 [ ] 86 [ ] 87 Must improve [ ] 82 [ ] 83 [ ] 84 [ ] 85 [ ] 86 [ ] 87

2. Boes the way you deal with people, your gestures and attitudes, characterize you as a minister?

Very good [ ] 82 [ ] 83 [ ] 84 [ ] 85 [ ] 86 [ ] 87 Good [ ] 82 [ ] 83 [ ] 84 [ ] 85 [ ] 86 [ ] 87 Must improve [ ] 82 [ ] 83 [ ] 84 [ ] 85 [ ] 86 [ ] 87

3. How does your dress and personal affects, your home (family), office, represent you as a minister?

$\begin{array}{lllllllllllllllll}\text { Very good } & \text { [ ] } & 82 & \text { [ ] } & 83 & \text { [ ] } & 84 & \text { [ ] } & 85 & \text { [ ] } & 86 & \text { [ ] } & 87 \\ \text { Good } & \text { [ ] } & 82 & \text { [ ] } & 83 & \text { [ ] } & 84 & \text { [ ] } & 85 & \text { [ ] } & 86 & \text { [ ] } & 87 \\ \text { Must improve } & \text { [ ] } & 82 & \text { [ ] } & 83 & \text { [ ] } & 84 & \text { [ ] } & 85 & \text { [ ] } & 86 & \text { [ ] } & 87\end{array}$

4. How does your personal appearance and that of your family represent the ministry?

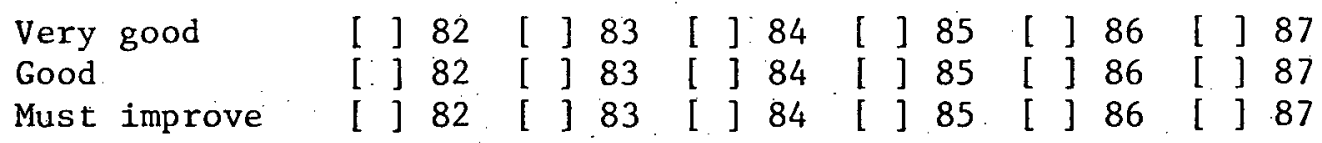

5. If you have a dictionary, a word book or a dictionary of synonymns, how often do you consult them?

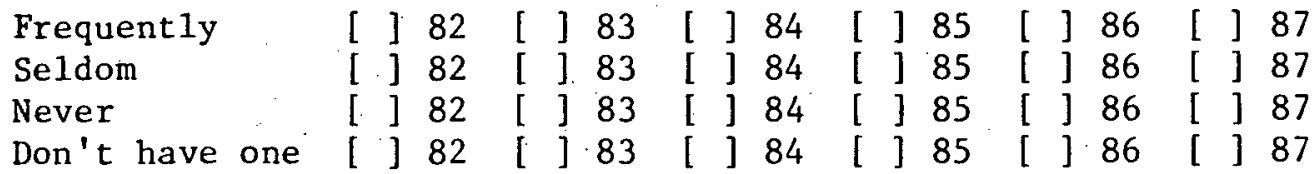


6. Through your wife, some other qualified person, or the use of a tape recorder, do you receive help in correcting the deficiencies that you might have in your preaching?

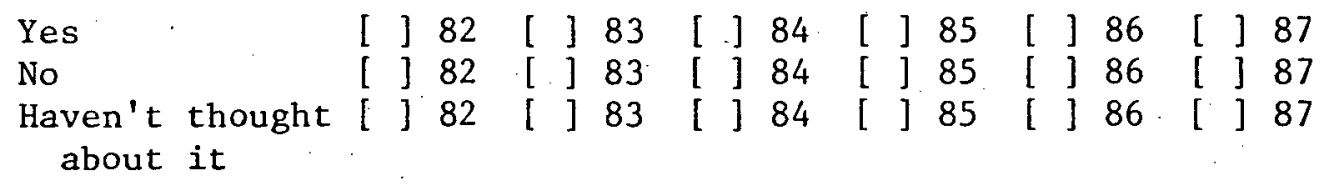

X. Programming

1. The program of the church is the sum of all the individual departmental programs. If these adequately answer the what, How, When, Where, and With whom criteria, they may be considered as adequate. How do you consider these departmental programs to be in your district?

Very good [ ] 82 [ ] 83 [ ] 84 [ ] 85 [ ] 86 [ ] 87 $\begin{array}{lllllllllll}\text { Good [ ] } 82 & \text { [. ] } 83 & \text { [ ] } 84 & \text { [ ] } 85 & \text { [ ] } 86 & \text { [ ] } 87\end{array}$ Must improve [ ] 82 [ ] 83 [ ] 84 [ ] 85 [ ] 86 [ ] 87

2. The evangelistic program is:

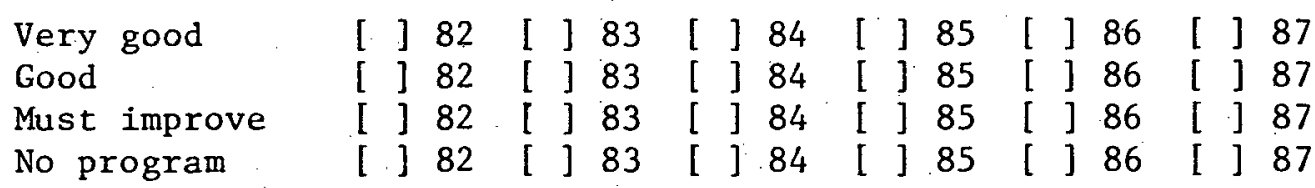

3. Your compliance to a personal program is:

$\begin{array}{llllllllllllll} & \text { Very good } 82 & \text { [ ] } 82 & \text { [ ] } 83 & \text { [ ] } 84 & \text { [ ] } 85 & \text { [ ] } 86 & \text { [ ] } 87\end{array}$ Good [ ] 82 [ ] 83 [ ] 84 [ ] 85 [ ] 86 [ ] 87 Must improve [ ] 82 [ [ ] 83 [ ] 84 [ ] 85 [ ] 86 [ ] 87

4. Your compliance with the departmental programs of your district is:

$\begin{array}{lllllllllllllllll} & \text { Very good } & \text { [ ] } 82 & 82 & \text { [ ] } 83 & \text { [ ] } 84 & \text { ['] } 85 & \text { [ ] } 86 & \text { [ ] } 87\end{array}$ Good [ ] 82 [ ] 83 [ ] 84 [ ] 85 [ ] 86 [ ] 87. Must improve : [ ] 82 [ [ ] 83 [ ] 84 [ ] 85 [ ] 86 [ ] 87

XI. Miscellaneous

1. Your knowledge of world events is:

$\begin{array}{llllllllllllllll}\text { Very good [ ] } 82 & \text { [ ] } 83 & \text { [ ] } 84 & \text { [ ] } 85 & \text { [ ] } 86 & \text { [ ] } 87\end{array}$ Good [ ] 82 [ ] 83 [ ] 84 [ ] ] 85 [ ] 86 [ ] 87 Lacking [ ] 82 [ ] 83 [ ] 84 [ ] 85 [ ] 86 [ ] 87 
XII. Finances

1. Your family participates in the planning of family finances:

Regularly [ ] 82 [ ] 83 [ [ ] 84 [ ] 85 [ ] 86 [ ] 87 Irregularly [ ] 82 [ ] 83 [ ] 84 [ ] 85 [ ] 86 [.] 87 $\begin{array}{lllllllllll}\text { Never [ ] } 82 & \text { [ ] } 83 & \text { [ ] } 84 & \text { [ ] } 85 & \text { [ ] } 86 & \text { [ ] } 87\end{array}$

XIII. Authority

1. How do you react to criticism?

Feel discouraged [ ] 82 [ ] 83 [. ] 84 [ ] 85 [ ] 86 [ ] 87

Feel annoyed [ ] 82 ['] 83 [ ] 84 [ ] 85 [ ] 86 [ ] 87

Evaluate it [ ] 82 [ ] 83 '[ ] 84 [ ] 85 [ ] 86 [ ] 87

React aggres- [ ] 82 [ ] 83 [ ] 84 [ ] 85 [ ] 86 [ ] 87 sively

2. Regarding the positions that everyone must take in life, how do you consider them:

$\begin{array}{lllllllllllllllll}\text { Adjustable } & \text { [ ] } 82 & \text { [ ] } 83 & \text { [ ] } 84 & \text { [ ] } 85 & \text { [ ] } 86 & \text { [ ] } 87\end{array}$ Stay neutral [ ] 82 [ ] 83 [ ] 84 [ ] 85 [ ] 86 [ ] 87 Modify for convenience sake [ ] 82 [ ] 83 [ ] 84 [ ] 85 [ ] 86 [ ] 87 Stick to it [ ] 82 [ ] 83 [ ] 84 [ ] 85 [ ] 86 [ ] 87

3. How do you feel regarding the performance of your ministerial functions?

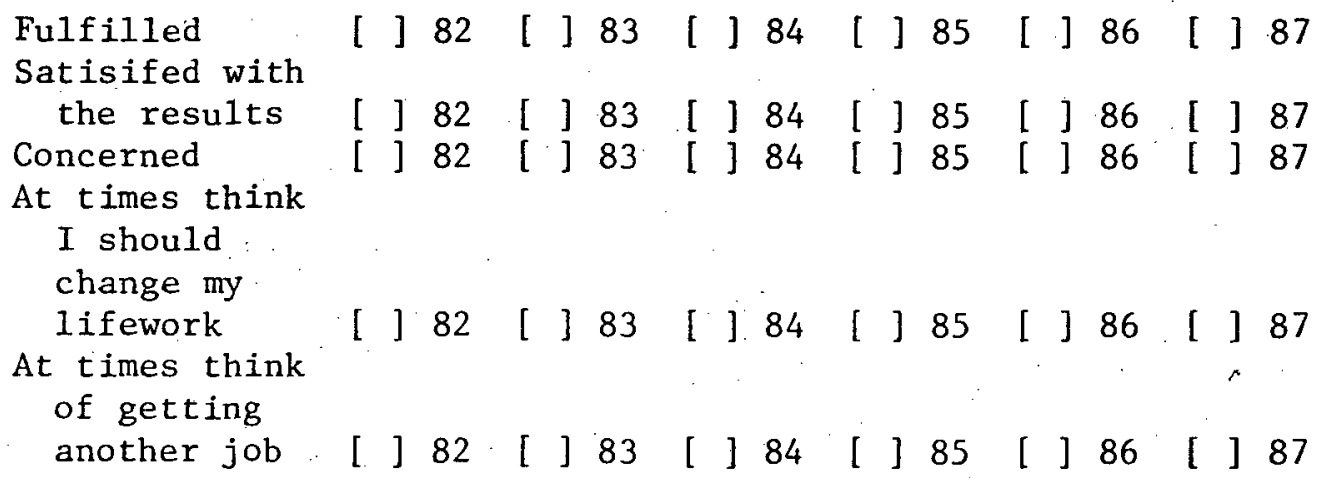

XIV. The Ministerial Couple

1. You feel that the communication between you and your wife is:

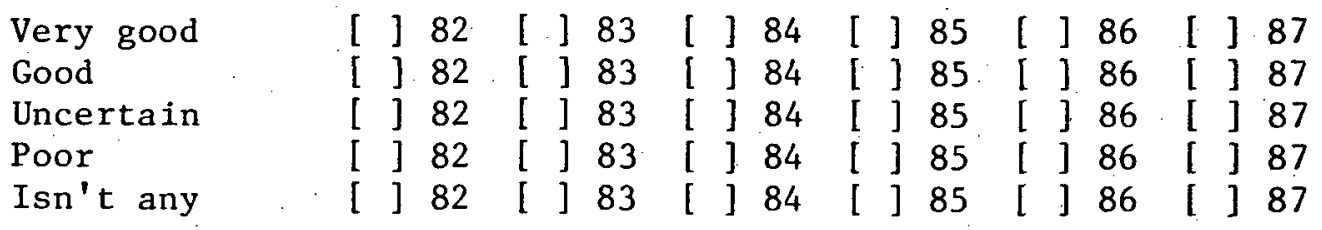


2. You feel that the communication between you and your husband is:

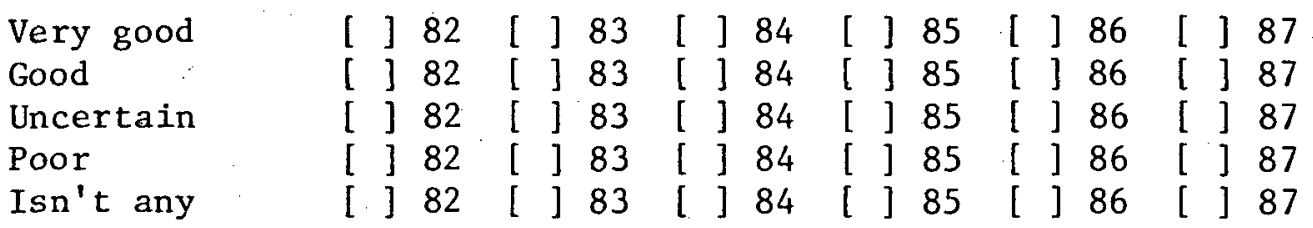

3. Indicate the time you and your spouse spend doing things together:

4. How do you consider the amount of time your husband spends with the children?

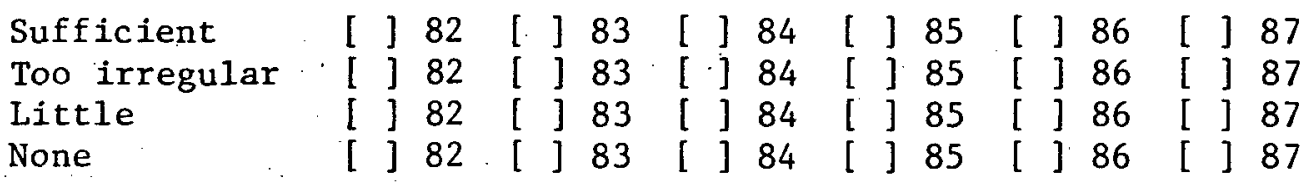

5. How do you consider the amount of time your husband spends with you?

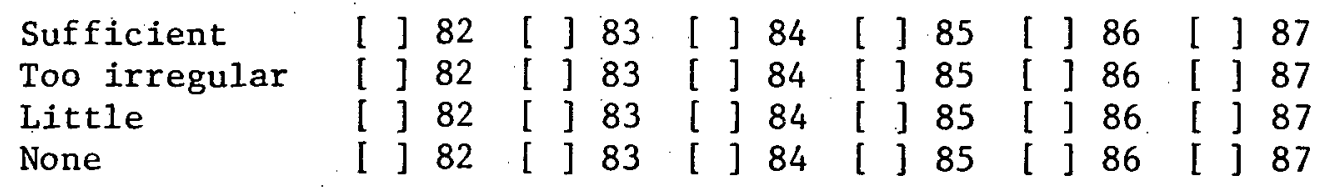


APPENDIX C

MINISTERIAL EVALUATION OF UNION D 
PLANO DE AVAIIAÇÃO I:AS ATIVIDADES DO OBREIRO

I- DADOS PESSOAIS:

1. NOME : $\ldots \ldots \ldots \ldots \ldots \ldots \ldots \ldots \ldots \ldots \ldots \ldots \ldots \ldots \ldots \ldots \ldots \ldots \ldots \ldots \ldots \ldots$

2. NASC. .............................. 19 ESTADO:

3. PREPARO:

CURSO

3.1. Primário

3.2. Secund. 19 Grau

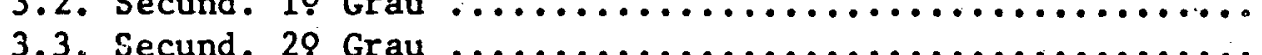

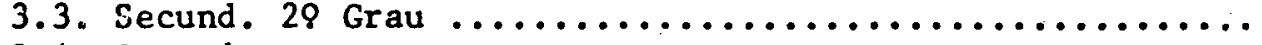

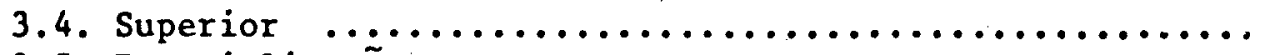

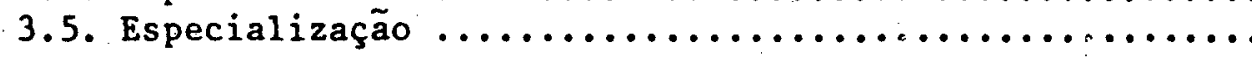

4. CAMPO OU INSTITUIÇÃO ONDE TRABALHOU E ATIVIDADE:
CIMPO - INSTITUIÇÃO

$\ldots \ldots \ldots \ldots \ldots \ldots \ldots \ldots \ldots \ldots$

$\ldots \ldots \ldots \ldots \ldots \ldots \ldots \ldots \ldots \ldots \ldots$

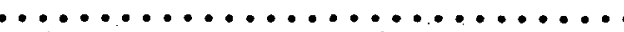

\section{ATIVIDADE . ANO}
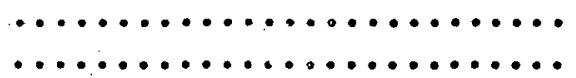

$\ldots \ldots \ldots \ldots \ldots \ldots \ldots \ldots \ldots \ldots$
-....

-....

-.*.

.....

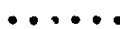

- . . . -

-......

$\cdots \cdots$

\section{PRATICA:}

5.1. Esporte

5.2. Hoby
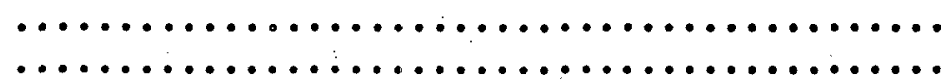

$(\ldots \ldots)$

$(\ldots)$

\section{FINANÇAS :}

6.1. Possui propriedade:

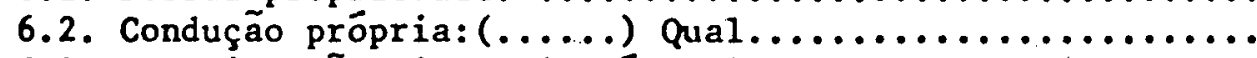

6.3. Sua situação financeira é normal $\ldots \ldots \ldots \ldots \ldots \ldots \ldots \ldots \ldots$

6.4. Segue um orçamento familiar: ...................

6.5. Recebe auxilio de equipamento profissiona? evangelistico:

$(\ldots)$

(.....

$(\ldots)$

$(\ldots)$

7. ATIVIDADE DENOMINACIONAIS:

\section{1. Possuí:}

7.1.1. Distintivo de Lider

7.1.2. Distintivos de Pregadores Leigos .............

7.1.3. Experiência na Colportagem - quantos anos......

$(\ldots)$

$(\ldots \ldots)$

$(\ldots)$

II- DADOS FAMILIARES:

1. NOME :

1.1. Esposa(0)

IDADE:

1.2. Filhos

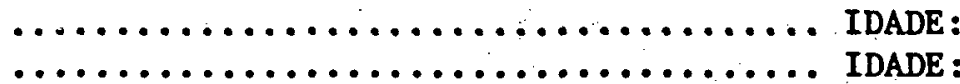

........................ IDADE:

$\ldots \ldots \ldots \ldots \ldots \ldots \ldots \ldots \ldots \ldots \ldots \ldots \ldots \ldots \ldots \ldots \ldots$ IDADE

2. PREPARO DA ESPOSA: 
2. PREPARO DA ESPOSA(Continuação)

CURSO ESCOLA

ANO

2.3. Secund. 28 Grau ..........................

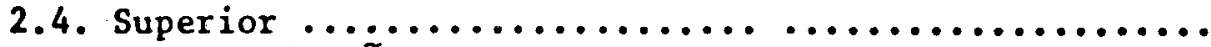

2.5. Especialização

3. ATIVIDADE DA ESPOSA:

3.1. Igreja:

3.2. Outras: $\ldots \ldots \ldots \ldots \ldots \ldots \ldots \ldots \ldots \ldots \ldots \ldots \ldots \ldots \ldots \ldots \ldots \ldots \ldots \ldots \ldots$

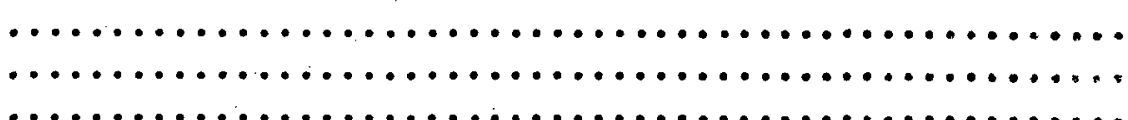

$\ldots \ldots \ldots \ldots \ldots \ldots \ldots \ldots \ldots \ldots \ldots \ldots \ldots \ldots \ldots \ldots \ldots \ldots \ldots \ldots \ldots$

3.3. Emprego:

4. FILHOS ESTUDAM EM ESCOLA DA IGREJA

$(\ldots$.

5. O CULTO FAMILIAR E REALIZADO REgULARMENTE

$(\ldots \ldots)$

6. OS FAMILIARES FREQUENTAM AOS CULTOS DA IGREJA REGULLARMENTE (...)

III- ATIVIDADE: ESPIRITUAL, CULTURAL E MINISTERIAL

1. BIBLIOTECA :

1.1. Número de livros $\ldots \ldots \ldots \ldots \ldots \ldots \ldots \ldots \ldots \ldots \ldots \ldots \ldots \ldots \ldots \ldots \ldots$

1.2. Possui:

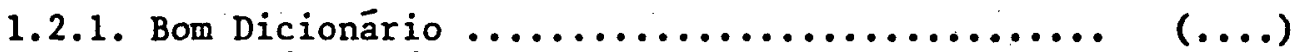

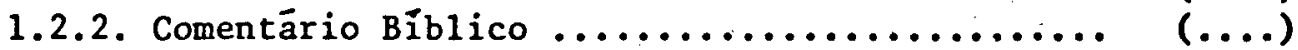

1.2.3. Livros Especializados .................. (...)

1.3. Assina:

1.3.1. Jornal

1.3.2. Revista Cultural-Profissional

$(\ldots)$

$(\ldots \ldots)$

1.3.3. Revista Adventista ........................)

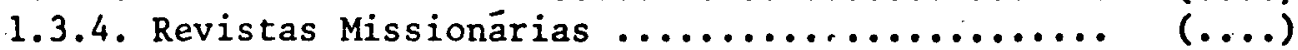

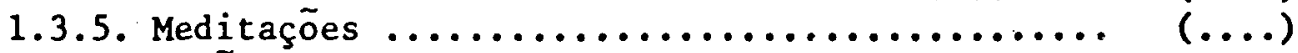

1.3.6. Liçōes .................................. (

1.4. Quantos livros comprou no ūltimo ano (12 meses) ..... (...)

1.5. Quais os livros que leu no $\bar{u} 1$ timo ano(12 meses) ...........

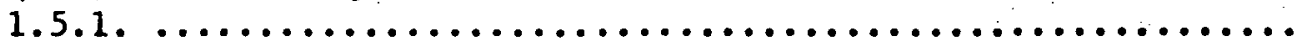

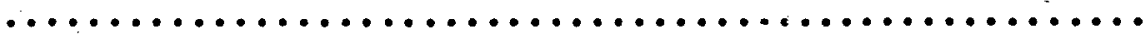

1.6. Quais os livros do Espírito de Profecia que jā, leu:

1.6.1.

2. POSSUI:

2.1. Relação atualizada das Igrejas e Grupos ............

2.2. Relação atualizada dos of iciais da Igreja ...........

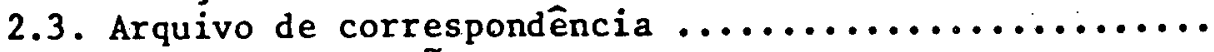

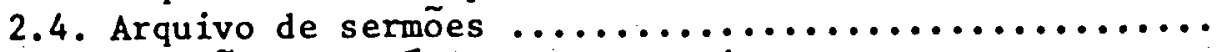

2.5. Seleção do Espírito de Profecia .......................

3. SEGUE REGULARMENTE:

3.1. Itinerário pelo Distrito ........................ (

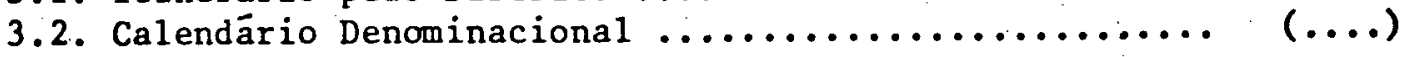

4. ESPECIFICAR O EQUIPAIENTO E MATERIAL EVANGELISTICO QUE PCSSUI : .... 
5. FREQUENTA REGULARMENTE:

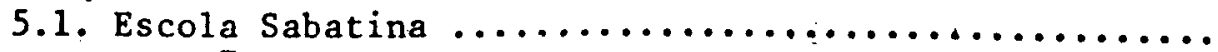

5.2. Reuniöes de professores $\ldots \ldots \ldots \ldots \ldots \ldots \ldots \ldots \ldots, \ldots$

5.3. Sociedade M.V.

$(\ldots .$.

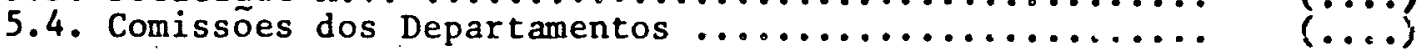

6. SEGUE REGULARMENTE UM PROGRAMA DE ESTULOS E DEVOÇ̃̃̃ PESSOAL. (...)

7. E MEMBRO (nome da Igreja)

7.1. Escola Sabatina

7.2. Igreja

8. ANALIZAR O RELATORIO ESTATÍSTICO DO OBREIRO - (Folha Anexa).

9. TEVE OPORTUNIDADE DE DIRIGIR OU PARTICIPAR:

$\square$ Organização de Igreja

Inauguração e/ou Dedicação de um Templo

$\square$ Fundar uma Escola

$\square$ Ordenação de Diācono e/ou Ancião

$\square$ Unção de um doente

10. TEM ALGUM DIFICULDADE COM COLEGA OU IRMÃO $\ldots \ldots \ldots \ldots \ldots$ (............

11. MENCIONE OS PONTOS POSITIVOS NO SEU SETOR DE TRABALHO: ...........

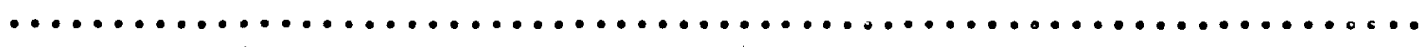

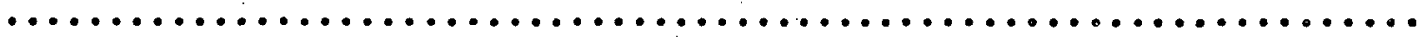

12. SEGUE UM PROGRAMA DE TRABALHO E ESTUDOS:

$\square$ Diärio

Trimestral
Semana1

Anual

Mensal

13. EM SEU ENTENDER QUJAS OS DESAFIOS EM SEU TRABALHO; (Distrito e Camo)

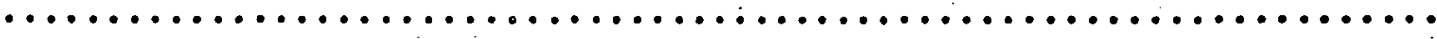

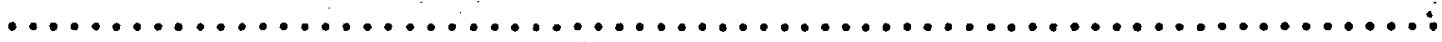

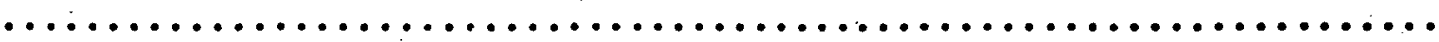

14. QUAIS SUAS SUGESTÕES A ADMINISTRAÇÃO PARA MELHORAR A PRODUÇÃO NO SEU SETOR DE TRABALHO:

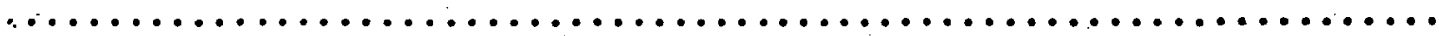

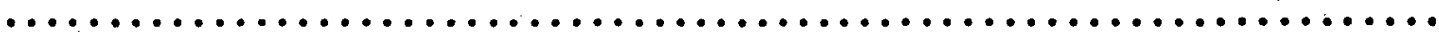

15. SENTE-SE REALIZADO NO TRABALHO QUE FAZ:

16. QUAIS OS DEPARTAMENTOS QUE MAIS LHE AGRADAM:

i7. TERIA ALGUM PROBLEMA EM ACEITAR UM CHAMADO PARA OUTRO CAMPO:........

18. RECOMENDAÇÕES DA COMISSÃO:

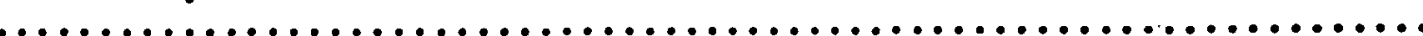

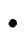


Analysis and evaluation guide on the activities of workers

I. PERSONAL DATA:

1. Name:

2. Birth date: of 19_. STATE :

3. Education:

Course

School

Year

3.1. Primary

3.2. Secondary

3.3. College

3.4. Specialies

3.5. Foreign language (name)

4. Work experience:

Conference/Institution

Position

Year

5. Interests:

5.1. Sports

5.2. Hobbies

6. Finances:

6.1. Property you own

6.2. Own vehicle: ) What?

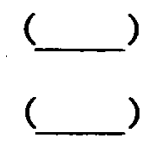

6.3. Is your financial situation normal?

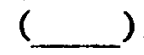


6.4. Do you follow a family budget?

6.5. Do you receive professional and evangelistic equipment allowance?

7. Denominational Activities:

7.1. Do you possess

7.1.1. Youth leader insignia?

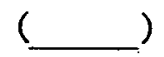

7.1.2. Lay preacher insignia?

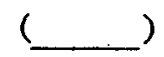

7.1.3. Colporteur experience? How long?

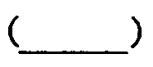

II. FAMILY DATA:

1. Name:

Age

1.1. Spouse

1.2. Children

2. Spouse's education:

Course

2.1. Primary

2.2. Secondary

2.3. College

2.4. Specialties

2.5. Foreign language (name) $\underline{\text { School }}$

$\underline{\text { Year }}$

3. Activities of Spouse:

3.1. Church 
3.2. Other

3.3. Job

4. Are the children attending church school?

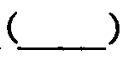

5. Do you family worship regularly?

6. Does the family attend church worship services regularly?

III. ACTIVITIES: Spiritual, Cultural and Ministeral

1. Personal library:

1.1. Number of books

1.2. Own:

1.2.1. Good dictionary

1.2.1. Bible commentary

1.3.1. Specialized books

1.4.1. Bibles: versions and different languages

1.3. Subscribe to:

1.3.1. Newspaper

1.3.2. Cultural-professional magazine

1.3.3. Adventist Review

1.3.4. The Ministry Magazine

1.3.5. Missionary magazine:

1.3.6. Devotional book

1.3.7: Sabbath School lesson

1.4. How many books did you purchase during the last year (12 months)? 
1.5. What books have you read during the last year (12 months)?

1.6. Are you a member of the SDA Book Club?

1.7. Which Spirit of Prophecy books have you read?

2. Do you have:

2.1. An up-to-date church and/or group membership file?

2.2. An up-to-date church officer's 1ist?

2.3. An up-to-date interest's file?

2.4. A correspondence file?

2.5. A sermon file?

2.6. A Spirit of Prophecy quotation file?

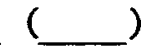

3. Do you regularly follow:

3.1. The district itinerary?

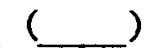

3.2. The denominational calendar?
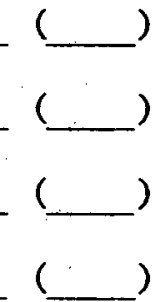

4. Specify the evangelistic equipment and material which you own:

[ ] Slide projector [ ] Typewriter [ ] Films

[ ] $16 \mathrm{~mm}$ projector [ ] Record player [ ] Others

[ ] Sound system [ ] S1ides 
5. Do you regularly attend:

5.1. Sabbath school

5.2. Sabbath school teacher's meeting?

5.3. Youth Society programs?

5.4. Departmental committees ("Penetration," for example)?

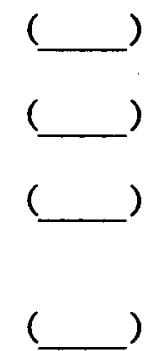

6. Do you regularly follow a work, study, and personal devotion program?

[ ] daily [ ] weekly [ ] monthly [ ] quarterly

7. Are you a member of (name the church):

7.1. Sabbath school

7.2. Church

8. Analyze the worker statistical report (see attached sheet)

9. Have you had the opportunity of conducting or participating in:

[ ] the organization of a church?

[ ] the Consecration or Dedication service of a temple?

[ ] the ordination of an elder or a deacon?

[ ] establishing a school?

[ ] the anointing of the sick?

10. Do you have any difficulty with a colleague or a brother?

11. Enumerate the positive aspects regarding your work in the last year: 
12. According to your understanding, what are the challenges of your work (district and conference)?

13. What suggestions would you make to the administration for improving the productivity of your work?

14. Which departments do you most enjoy?

15. Do you feel fulfilled in your present work?

16. Would you experience any difficulties in accepting a call to another conference?

17. Recommendations of the [evaluation] committee:

of 19

Committee: 
SUMMARY OF WORKER'S STATISTICAL REPORTS

\begin{tabular}{|c|c|c|c|c|c|c|c|}
\hline Mo. Items & $\begin{array}{l}\text { Ser- } \\
\text { mons }\end{array}$ & $\begin{array}{l}\text { Bible } \\
\text { Studies }\end{array}$ & $\begin{array}{l}\text { Meetings } \\
\text { At tended }\end{array}$ & $\begin{array}{c}\text { Pastoral } \\
\text { calls }\end{array}$ & $\begin{array}{c}\text { Liter. } \\
\text { Distrib. }\end{array}$ & $\begin{array}{r}\text { No. } \\
\text { Bap. }\end{array}$ & Observations \\
\hline January & & & & & & & \\
\hline February & & & & & & & \\
\hline March & & & & & & & \\
\hline April & & & & & & & \\
\hline May & & & & & & & \\
\hline June & & & & & & & \\
\hline July & & & . & & & & \\
\hline August & & & & & & & \\
\hline Septembe & & & & & & & \\
\hline October & & & & & & & \\
\hline November & & & & & & & \\
\hline December & & & & & & & \\
\hline Total & & & & & & & \\
\hline
\end{tabular}


APPENDIX D

EVALUATION INSTRUMENT UNION E 
ESCALAS VALORATIVAS AUTOEVALUACION (a) Y EVALUACION POR

Metodo W.H.W

\section{CUALIDADES ESPIRITUALES}

A. CONSAGRACION

(O.E., 116)

(J.T., 2:228)

B. FIDELIDAD E INTEGRIDAD (O.E., 151)

C. HUMILDAD

(O.E., 150)

D. FERVOR - ENTUSIASMO

(O.E., 151)

(J.T., 2:228)

E. DEVOCION PERSONAL (O.E., 152)

F. DISCERNIMIENTO (Ezeq $44: 23, E . D ., 227$ )

\section{OBSERVACION DEL MISIONERO ADVENTISTA}

\begin{tabular}{|c|c|c|c|c|}
\hline Ardiente $y$ total & Mucha & $\frac{(3)}{\text { Término medio }}$ & $\begin{array}{l}\quad(2) \\
\text { Algo descuidado } \\
\text { y liviano }\end{array}$ & Frivolo \\
\hline $\begin{array}{l}\text { (5) } \\
\text { Estrictamente fiel, } \\
\text { sin temer las presi- } \\
\text { pnes de la mayoría }\end{array}$ & $\begin{array}{l}\text { (4) } \\
\text { Fiel y claramente } \\
\text { definido en mante- } \\
\text { ner los principios }\end{array}$ & Fiel y leal & $\begin{array}{l}\text { (2) } \\
\text { Algo liberal, sin } \\
\text { posición clara } y \\
\text { definida }\end{array}$ & $\begin{array}{l}\text { (1) } \\
\text { Muy liberal y per- } \\
\text { misivo. No es fiel }\end{array}$ \\
\hline $\begin{array}{l}\quad \text { (5) } \\
\text { Muy humilde y } \\
\text { paciente. Reconoce } \\
\text { sus limitaciones }\end{array}$ & $\begin{array}{c}\text { (4) } \\
\text { Humilde } y \text { sereno }\end{array}$ & $\begin{array}{c}\text { (3) } \\
\text { Bastante humilde. } \\
\text { Lucha por ser más }\end{array}$ & \begin{tabular}{|l|}
\multicolumn{1}{c|}{$(2)$} \\
Poco humilde. Aire \\
de superioridad. \\
Justicia propia
\end{tabular} & $\begin{array}{l}\text { (1) } \\
\text { Orgulloso e impa- } \\
\text { ciente. El yo es } \\
\text { dominante. A tocas } \\
\text { sus acciones encu- } \\
\text { entra explicación }\end{array}$ \\
\hline $\begin{array}{l}\text { ( } 5) \\
\text { Muy ferviente } \\
\text { y entusiasta } \\
\text { continuamente }\end{array}$ & $\begin{array}{l}\quad(4) \\
\text { Es siempre fer- } \\
\text { viente } y \text { entusi- } \\
\text { asta }\end{array}$ & $\begin{array}{l}\text { ( } 3) \\
\text { Casi siempre fer- } \\
\text { viente } y \text { entusi- } \\
\text { asta }\end{array}$ & \begin{tabular}{|l|}
\multicolumn{1}{c|}{$(2)$} \\
Fervor y entusias- \\
mo intermitentes. \\
Más bien apático
\end{tabular} & \begin{tabular}{|l|}
\multicolumn{1}{|c|}{ (1) } \\
Muy apático e \\
indiferente
\end{tabular} \\
\hline $\begin{array}{l}\text { (5) } \\
\text { Cristiano de mucha } \\
\text { oración y devoción. } \\
\text { Se trasunta en su } \\
\text { vida }\end{array}$ & $\begin{array}{l}\text { (4) } \\
\text { Lleva una vida } \\
\text { de devoción per- } \\
\text { sonal notable }\end{array}$ & $\begin{array}{c}\text { (3) } \\
\text { su devocion per- } \\
\text { sonal es normal }\end{array}$ & $\begin{array}{l}\text { (2) } \\
\text { Poca oración y } \\
\text { devoción personal }\end{array}$ & $\begin{array}{l}\text { (1) } \\
\text { Ninguna } \\
\text { devociōn }\end{array}$ \\
\hline $\begin{array}{l}\text { (5) } \\
\text { Agudo, rapido y } \\
\text { claro en discernir } \\
\text { lo conveniente de lo } \\
\text { inconveniente }\end{array}$ & $\begin{array}{l}\text { (4) } \\
\text { Discierne con clari } \\
\text { dad lo que conviene } \\
\text { en los asuntos no } \\
\text { legislados especifi- } \\
\text { camente }\end{array}$ & $\begin{array}{l}\text { (3) } \\
\text { Aplica bien los } \\
\text { principios bíblicos } \\
\text { generales a los } \\
\text { asuntos personales } \\
\text { y particulares }\end{array}$ & $\begin{array}{l}\text { (2) } \\
\text { De poco discerni- } \\
\text { miento. Pocas ve- } \\
\text { ces acierta en } \\
\text { aplicar los prin- } \\
\text { cipios generales a } \\
\text { casos particulares }\end{array}$ & \begin{tabular}{|l|}
\multicolumn{1}{|c|}{$(1)$} \\
Tiene criterios mun \\
confusos acerca \\
de lo bueno y de \\
lo malo
\end{tabular} \\
\hline
\end{tabular}


A. INTELIGENCIA

(O.E., 116)

B. CAPTACION

C. CONOCIMIENTO BIBLICO

D. cultura general

E. SENTIDO COMUN

F. PREDICACION

C. EXPRESION VERBAL

H. EXPRESION ESCRITA

\begin{tabular}{|c|c|c|c|c|}
\hline $\begin{array}{c}\text { (5) } \\
\text { Superdotado }\end{array}$ & $\begin{array}{r}\text { (4) } \\
\text { Superior }\end{array}$ & ${ }^{(3)}$ & $\begin{array}{c}(2) \\
\text { Torpe y lento }\end{array}$ & $\begin{array}{l}\qquad 1) \\
\text { Probablemente } \\
\text { tenga alguma } \\
\text { deficiencia }\end{array}$ \\
\hline $\begin{array}{l}\text { (5) } \\
\text { Facilidad extrema } \\
\text { de captación }\end{array}$ & $\begin{array}{l}\text { (4) } \\
\text { Entiende com ra- } \\
\text { pidez sin que se } \\
\text { le especifique }\end{array}$ & $\begin{array}{l}\text { Capta bien cuando } \\
\text { ve claramente }\end{array}$ & $\begin{array}{l}\quad(2) \\
\text { Sólo capta cosas } \\
\text { notables }\end{array}$ & $\begin{array}{l}\text { (1) } \\
\text { Lento para captar } \\
\text { cosas notables }\end{array}$ \\
\hline Teológo & $\begin{array}{l}\quad(4) \\
\text { Conocimiento } \\
\text { bíblico muy } \\
\text { amplio } \\
\end{array}$ & $\begin{array}{l}\quad(3) \\
\text { Posee conocimiento } \\
\text { normal }\end{array}$ & $\begin{array}{l}\quad(2) \\
\text { Escaso, bastante } \\
\text { pobre su conoci- } \\
\text { miento bíblico } \\
\end{array}$ & $\begin{array}{l}\quad \text { (1) } \\
\text { Paupérrimo y } \\
\text { deficiente }\end{array}$ \\
\hline $\begin{array}{r}\text { (5) } \\
\text { Amplísima }\end{array}$ & $\begin{array}{c}\text { (4) } \\
\text { Muy culto }\end{array}$ & Cultura normal & $\begin{array}{c}(2) \\
\text { Escasa cultura }\end{array}$ & $\begin{array}{l}\text { (1) } \\
\text { Visiblemente } \\
\text { inculto }\end{array}$ \\
\hline $\begin{array}{l}\quad(5) \\
\text { Muy criterioso ante } \\
\text { las situaciones } \\
\text { dificiles y nuevas } \\
\text { que se le plantean }\end{array}$ & $\begin{array}{l}\quad(4) \\
\text { Criterioso. En- } \\
\text { cara y resuelve } \\
\text { bien los proble- } \\
\text { mas y situaciones } \\
\text { nuevas }\end{array}$ & $\begin{array}{l}\quad(3) \\
\text { Casi siempre cri- } \\
\text { terioso y bien } \\
\text { ubicado }\end{array}$ & $\begin{array}{l}\text { (2) } \\
\text { Poco criterioso. } \\
\text { Pocas veces acier- } \\
\text { ta con una solucion }\end{array}$ & $\begin{array}{l}\quad(1) \\
\text { Muy desubicado. } \\
\text { Escaso sentido } \\
\text { comun. Su falta } \\
\text { de criterio crea } \\
\text { frequentes pro- } \\
\text { blemas }\end{array}$ \\
\hline $\begin{array}{l}\quad(5) \\
\text { Excepcional, siempre } \\
\text { tiene mensajes cla- } \\
\text { ros, definidos y } \\
\text { edificantes }\end{array}$ & $\begin{array}{l}\quad(4) \\
\text { Mensajes claros } \\
\text { y edificantes para } \\
\text { la iglesia }\end{array}$ & $\begin{array}{l}\text { (3) } \\
\text { Predicación buena } \\
\text { y clara }\end{array}$ & $\begin{array}{l}\text { Sermones confusos } \\
y \text { de poco conte- } \\
\text { nido }\end{array}$ & $\begin{array}{l}\text { (1) } \\
\text { Predicación pobre } \\
y \text { sin sentido }\end{array}$ \\
\hline $\begin{array}{l}\quad(5) \\
\text { Extraordinaria y } \\
\text { correctisíma }\end{array}$ & $\begin{array}{l}\text { (4) } \\
\text { Muy buena y } \\
\text { correcta }\end{array}$ & $\begin{array}{l}(3) \\
\text { Buena y correcta }\end{array}$ & Escasa & $\begin{array}{l}\text { (1) } \\
\text { Deficiente, disle- } \\
\text { xia }\end{array}$ \\
\hline $\begin{array}{c}(5) \\
\text { Escritor de fuste }\end{array}$ & $\begin{array}{l}\quad \text { (4) } \\
\text { Supera al término } \\
\text { medio }\end{array}$ & Buena $y$ correcta & $\begin{array}{l}\quad(2) \\
\text { Con algunos erro- } \\
\text { res gramaticales y } \\
\text { de construcción }\end{array}$ & Mala y pobre \\
\hline
\end{tabular}




\begin{tabular}{|c|c|c|c|c|c|c|}
\hline \multicolumn{2}{|c|}{ III. EMOTIVIOAD } & \multicolumn{5}{|c|}{ Cont. - Metodo W.H.W. } \\
\hline A. & REACCION EMOCIONAL & \begin{tabular}{|l|}
\multicolumn{1}{|c|}{$(5)$} \\
Muy equilibrada y \\
controlada
\end{tabular} & $\begin{array}{l}\quad(4) \\
\text { Emotivamente } \\
\text { maduro }\end{array}$ & $\begin{array}{l}\text { (3) } \\
\text { Reacción general- } \\
\text { mente con trolada }\end{array}$ & $\begin{array}{l}\text { Suele reaccionar } \\
\text { vivamente. Poco } \\
\text { control }\end{array}$ & $\begin{array}{l}\quad \text { (1) } \\
\text { Muy irritable, } \\
\text { emocionalmente } \\
\text { descontrolado }\end{array}$ \\
\hline B. & $\begin{array}{l}\text { ADAPTABILIDAD A LOS } \\
\text { CAMBIOS Y TRASLADOS }\end{array}$ & $\begin{array}{l}\text { (5) } \\
\text { Se adapta muy bien } \\
\text { a toda nueva situ- } \\
\text { ación }\end{array}$ & $\begin{array}{l}\text { (4) } \\
\text { Se adapta sin ma- } \\
\text { yores dificultades. } \\
\text { Elabora positiva- } \\
\text { mente los cambios }\end{array}$ & $\begin{array}{l}\text { Con algo de esfu- } \\
\text { erzo logra adap-. } \\
\text { tarse }\end{array}$ & Se adapta a medias & $\begin{array}{l}\quad \text { (1) } \\
\text { No se adapta. } \\
\text { Vive en una per- } \\
\text { manente frustra- } \\
\text { ción }\end{array}$ \\
\hline c. & $\begin{array}{l}\text { ACTITUD FRENTE A } \\
\text { LAS DIFICULTADES }\end{array}$ & $\begin{array}{l}\text { (5) } \\
\text { Las afronta con } \\
\text { toda decision y } \\
\text { lucha hasta vencer } \\
\text { las. Es muy } \\
\text { optimista }\end{array}$ & \begin{tabular}{|l|} 
\\
Lucha bastante an- \\
tes de darse por \\
vencido. Es \\
optimista
\end{tabular} & $\begin{array}{l}\text { (3) } \\
\text { No las elude. Hace } \\
\text { esfuerzos razona- } \\
\text { bles para vencer- } \\
\text { las }\end{array}$ & \begin{tabular}{|l} 
(2) \\
Trata de eludirlas. \\
No se esfuerza. \\
Pronto se abate. \\
Bastante pesimista.
\end{tabular} & $\begin{array}{l}\text { Evade las dificul- } \\
\text { tades de antema- } \\
\text { no. Muy pesi- } \\
\text { mista }\end{array}$ \\
\hline D. & $\begin{array}{l}\text { REACCION FRENTE AL } \\
\text { ELOCIO }\end{array}$ & $\begin{array}{l}\text { (5) } \\
\text { Muy mesurada. } \\
\text { Nunca se deja em- } \\
\text { briagar por él }\end{array}$ & $\begin{array}{l}\text { (4) } \\
\text { Reacción contro- } \\
\text { lada }\end{array}$ & $\begin{array}{l}\text { (3) } \\
\text { Casi siempre se } \\
\text { ubica bien ante } \\
\text { el elogio }\end{array}$ & \begin{tabular}{|c|} 
(2) \\
Más bien indiferente \\
o tiende a la euforia
\end{tabular} & $\begin{array}{l}\text { (1) } \\
\text { Apático o se } \\
\text { vuelve eufórico }\end{array}$ \\
\hline E. & $\begin{array}{l}\text { REACCION FRENTE A } \\
\text { LA CRITICA U OBSER- } \\
\text { VACIONES }\end{array}$ & $\begin{array}{l}\text { (5) } \\
\text { Siempre las acepta } \\
\text { y selecciona }\end{array}$ & $\begin{array}{l}\text { (4) } \\
\text { Las recibe bien } \\
\text { cuando son cons- } \\
\text { tructivas y no se } \\
\text { abate ante las } \\
\text { otras }\end{array}$ & $\begin{array}{l}\quad(3) \\
\text { Suele aceptar las } \\
\text { constructivas. A } \\
\text { veces reacciona } \\
\text { vivamente }\end{array}$ & $\begin{array}{l}\quad(2) \\
\text { Pocas veces acepta } \\
\text { observaciones. } \\
\text { Tiende a ofuscarse }\end{array}$ & $\begin{array}{l}\text { ( } 1) \\
\text { Nunca acepta las } \\
\text { observaciones } \\
\text { aūn las cons- } \\
\text { tructivas }\end{array}$ \\
\hline F. & $\begin{array}{l}\text { DISPOSICION PARA } \\
\text { ACEPTAR LOS PLANES }\end{array}$ & $\begin{array}{l}\text { (5) } \\
\text { Los acepta con mu- } \\
\text { cho entusiasmo y } \\
\text { anade de su pro- } \\
\text { pria cosecha para } \\
\text { adaptarlos y mejo- } \\
\text { rarlos }\end{array}$ & $\begin{array}{l}\text { (4) } \\
\text { Luena disposición. } \\
\text { mismo. }\end{array}$ & $\begin{array}{l}\quad(3) \\
\text { Casi siempre los } \\
\text { acepta, a veces } \\
\text { es un poco nega- } \\
\text { tivo }\end{array}$ & \begin{tabular}{|l} 
(2) \\
Raras veces los \\
acepta. Casi siem- \\
pre encuentra ob- \\
jeciones y pretextos \\
para rechazarlos
\end{tabular} & $\begin{array}{l}\text { (1) } \\
\text { Siempre los re- } \\
\text { chaza aunque no } \\
\text { tiene los propios } \\
\text { Es reaccionario } \\
\text { y le falta fe }\end{array}$ \\
\hline c. & $\begin{array}{l}\text { DISPOCISION PARA } \\
\text { AFRONTAR LOS YERROS } \\
\text { Y DIVERCENCIAS }\end{array}$ & $\begin{array}{l}\text { (5) } \\
\text { Es amplio y humil- } \\
\text { de. No guarda } \\
\text { rencor o disgusto. } \\
\text { Devuelve bien por } \\
\text { mal }\end{array}$ & $\begin{array}{l}\text { (4) } \\
\text { Perdona y olvida } \\
\text { con facilidad las } \\
\text { situaciones } \\
\text { enojosas }\end{array}$ & $\begin{array}{l}\quad(3) \\
\text { Suele olvidar los } \\
\text { agravios aunque } \\
\text { no sin grandes } \\
\text { esfuerzos }\end{array}$ & $\begin{array}{l}\text { (2) } \\
\text { Conserva por bast- } \\
\text { tante tiempo el dis- } \\
\text { gusto y la ofensa. } \\
\text { A veces es vengati- } \\
\text { vo }\end{array}$ & $\begin{array}{l}\text { (1) } \\
\text { Es rencoroso y } \\
\text { vengativo. Paga } \\
\text { mal por mal. No } \\
\text { olvida nunca el } \\
\text { agravio }\end{array}$ \\
\hline
\end{tabular}


A. RESPONSABILIDAD

B. ORGANIZACION Y PLANIFICACION

C. LABORIOSIDAD Y
DEDICACION O.E. 151)

D. INICIATIVA PERSONAL

E. DEstreza manual

F. RENDIMIENTO $Y$ CONCRECION

C. DISPOSICION PARA LA TAREA

\begin{tabular}{|c|c|c|c|c|}
\hline $\begin{array}{l}\text { (5) } \\
\text { Sumamente responsa- } \\
\text { ble. Casi obsesivo. } \\
\text { Siempre cumple }\end{array}$ & $\begin{array}{l}\text { (4) } \\
\text { Responsable. Cum- } \\
\text { ple bien con lo que } \\
\text { se le encarga }\end{array}$ & $\begin{array}{l}\text { Casi siempre cum- } \\
\text { ple con sus tareas }\end{array}$ & $\begin{array}{l}\quad(2) \\
\text { Bastante irresponsa- } \\
\text { ble. Con frecuencia } \\
\text { deja de cumplir con } \\
\text { tareas y citas }\end{array}$ & $\begin{array}{l}\text { (1) } \\
\text { Irresponsable. No } \\
\text { se puede confiar }\end{array}$ \\
\hline $\begin{array}{l}\qquad(5) \\
\text { Muy ordenado y } \\
\text { previsor. Excelente } \\
\text { organizador }\end{array}$ & $\begin{array}{l}\quad(4) \\
\text { Planifica bien y es } \\
\text { ordenado. Procura } \\
\text { cumplir sus planes }\end{array}$ & $\begin{array}{l}\text { (3) } \\
\text { Planifica a veces. } \\
\text { Algo previsor }\end{array}$ & $\begin{array}{l}\text { (2) } \\
\text { Bastante desordenado } \\
\text { e improvisador. Casi } \\
\text { siempre está confun- } \\
\text { dido ante la tarea }\end{array}$ & $\begin{array}{l}\text { (1) } \\
\text { Muy desordenado. } \\
\text { Cambia de planes } \\
\text { siempre, si es que } \\
\text { tiene alguno }\end{array}$ \\
\hline $\begin{array}{l}\quad \text { (5) } \\
\text { Se dedica por comple- } \\
\text { to a la tarea que se } \\
\text { le confiere. Muy } \\
\text { trabajador }\end{array}$ & $\begin{array}{l}\quad(4) \\
\text { Trabajador } \\
\text { activo }\end{array}$ & $\begin{array}{l}\quad \text { (3) } \\
\text { Bastante activo. A } \\
\text { veces distrae tiempo } \\
\text { para sus asuntos } \\
\text { personales }\end{array}$ & $\begin{array}{l}\quad(2) \\
\text { Poco trabajador. } \\
\text { Algo perezoso y dor- } \\
\text { milón. Dedica bas- } \\
\text { tante tiempo a cosas } \\
\text { personales }\end{array}$ & $\begin{array}{l}\text { (1) } \\
\text { Haragan. Perezoso. } \\
\text { Dormilón. Lo poco } \\
\text { que realiza son } \\
\text { asuntos personales }\end{array}$ \\
\hline $\begin{array}{l}\qquad(5) \\
\text { Mucha iniciativa } \\
\text { propria. Nunca hay } \\
\text { necesidad que se le } \\
\text { marque la tarea }\end{array}$ & $\begin{array}{l}\text { (4) } \\
\text { Tiene iniciativa. } \\
\text { No hay necesidade } \\
\text { que se le senale }\end{array}$ & $\begin{array}{l}\text { (3) } \\
\text { Algo de iniciativa. } \\
\text { Hay que senálarle } \\
\text { a veces la tarea }\end{array}$ & $\begin{array}{l}\text { (2) } \\
\text { Pocas veces se le } \\
\text { ocurre iniciar algo }\end{array}$ & $\begin{array}{l}\text { (1) } \\
\text { Siempre se le debe } \\
\text { señalar lo que debe } \\
\text { hacer }\end{array}$ \\
\hline $\begin{array}{l}\text { (5) } \\
\text { Muy habilidoso y } \\
\text { practico para oficios } \\
\text { manuales y artes }\end{array}$ & \begin{tabular}{|l|}
\multicolumn{1}{|c|}{$(4)$} \\
Realiza bien algunas \\
tareas manuales $y$ \\
artisticas
\end{tabular} & $\begin{array}{l}\text { (3) } \\
\text { Cierta destreza en } \\
\text { algunos trabajos } \\
\text { manuales }\end{array}$ & \begin{tabular}{|l|}
\multicolumn{1}{c|}{$(2)$} \\
Bastante torpe y poca \\
practicidad
\end{tabular} & $\begin{array}{l}\text { (1) } \\
\text { Muy torpe e inūtil } \\
\text { para trabajos } \\
\text { manuales }\end{array}$ \\
\hline $\begin{array}{c}\text { (5) } \\
\text { Muy productivo y } \\
\text { eficaz en su trabajo }\end{array}$ & $\begin{array}{l}\quad(4) \\
\text { Rinde bien. Sabe } \\
\text { concretar sus es- } \\
\text { fuerzos }\end{array}$ & $\begin{array}{l}\text { (3) } \\
\text { Concreta bastante } \\
\text { su trabajo. Grado } \\
\text { normal de rendi- } \\
\text { miento }\end{array}$ & $\begin{array}{c}\text { (2) } \\
\text { Muy disperso. } \\
\text { Concreta poco }\end{array}$ & $\begin{array}{l}\quad(1) \\
\text { Rendimiento y } \\
\text { resultados nulos }\end{array}$ \\
\hline $\begin{array}{l}\quad(5) \\
\text { Muy entusiasta. } \\
\text { Siempre dispuesto, no } \\
\text { se atiene a un } \\
\text { horario }\end{array}$ & $\begin{array}{l}\text { (4) } \\
\text { Tiene buena dispo- } \\
\text { sicion. No se mide } \\
\text { por horarió }\end{array}$ & $\begin{array}{l}\text { (3) } \\
\text { Trabaja estricta- } \\
\text { mente lo indispen- } \\
\text { sable y cumple sólo } \\
\text { su horario }\end{array}$ & $\begin{array}{l}\quad(2) \\
\text { Necesita de frecuen- } \\
\text { tes estimulos para } \\
\text { trabajar. Bastante } \\
\text { esquivo para las tareas }\end{array}$ & $\begin{array}{l}\text { (1) } \\
\text { Trabaja solo cuando le } \\
\text { controlan y obligan. } \\
\text { Debe recibir siempre } \\
\text { estiimulos }\end{array}$ \\
\hline
\end{tabular}


Cont. - Metodo W.H.W.

\section{A. LIDERAZCO}

B. ABNECACION Y ALO ALOCENTRISMO (O.E., 249, 524)

C. SIMPATIA Y SOCIABILIDADE (O.E., 147)

D. COMPANERISMO $Y$ ESPIRITU DE EQUIPO

E. VALORACION PROPRIA $Y$ AJENA

F. TRATO CON LOS HERMANOS (O.E., 198)

C. ARRECLO PERSONAL (O.E., 152, 182)

\begin{tabular}{|c|c|c|c|c|}
\hline $\begin{array}{l}\quad(5) \\
\text { Líder por excelen- } \\
\text { cia arrastra sin } \\
\text { imponerse }\end{array}$ & $\begin{array}{l}\qquad(4) \\
\text { Personalidad pre- } \\
\text { valente. Tiene } \\
\text { ascendiente }\end{array}$ & $\begin{array}{l}\text { (3) } \\
\text { Bastante personalidad } \\
\text { pero no influye dema- } \\
\text { siado sobre los } \\
\text { demás }\end{array}$ & $\begin{array}{l}\text { (2) } \\
\text { Sölo logra imponer- } \\
\text { se por la fuerza, } \\
\text { se deja influir } \\
\text { fácilmente }\end{array}$ & $\begin{array}{l}\quad(1) \\
\text { No goza de pres } \\
\text { tigio, más bien } \\
\text { es rechazado } \\
\text { como lider }\end{array}$ \\
\hline $\begin{array}{l}\quad(5) \\
\text { Muy desinteresado } \\
\text { por sus cosas. } \\
\text { Atiende primero } \\
\text { los intereses ajenos }\end{array}$ & $\begin{array}{l}\text { (4) } \\
\text { Raramente antepo- } \\
\text { ne sus intereses a } \\
\text { los de los otros }\end{array}$ & $\begin{array}{l}\text { A tiende con igual } \\
\text { preferencia sus } \\
\text { intereses y los ajenos }\end{array}$ & $\begin{array}{l}\text { Tiene a la compla- } \\
\text { cencia propria. } \\
\text { Piensa poco en los } \\
\text { demás }\end{array}$ & $\begin{array}{l}\quad(1) \\
\text { Atiende sus con } \\
\text { veniencias y ven } \\
\text { tajas e intereses } \\
\text { proprios. No } \\
\text { piensa en los } \\
\text { demás }\end{array}$ \\
\hline $\begin{array}{l}\text { (5) } \\
\text { Muy simpático. } \\
\text { Personalidad muy } \\
\text { agradable y atra- } \\
\text { yente }\end{array}$ & $\begin{array}{l}\text { (4) } \\
\text { Mantiene siempre } \\
\text { una actitud agra- } \\
\text { dable }\end{array}$ & $\begin{array}{l}\text { Es algo variable } \\
\text { en su trato con los } \\
\text { demás }\end{array}$ & $\begin{array}{l}\quad(2) \\
\text { Tiende a aislarse. } \\
\text { Poco comunicativo. } \\
\text { algo tosco e intro- } \\
\text { vertido }\end{array}$ & $\begin{array}{l}\quad(1) \\
\text { Lacónico, inco- } \\
\text { municativo, } \\
\text { antipatico }\end{array}$ \\
\hline $\begin{array}{l}\text { (5) } \\
\text { Excellente compa- } \\
\text { nero. Muy bueno } \\
\text { para trabajar en } \\
\text { equipo }\end{array}$ & $\begin{array}{l}\text { (4) } \\
\text { Es buen compańe- } \\
\text { ro, y se adapta a } \\
\text { trabajar en } \\
\text { equipo }\end{array}$ & $\begin{array}{l}\text { Compañero leal, } \\
\text { aunque prefiere } \\
\text { trabajar solo }\end{array}$ & \begin{tabular}{|l|}
\multicolumn{1}{|c|}{$(2)$} \\
No siempre es leal \\
Con sus compañeros \\
Busca ventajas \\
personales \\
\end{tabular} & $\begin{array}{l}\quad \text { (1) } \\
\text { No es franco. } \\
\text { Sus compañeros } \\
\text { le temen y re- } \\
\text { chazan }\end{array}$ \\
\hline $\begin{array}{l}\quad(5) \\
\text { Muy respetuoso de } \\
\text { la opinion ajena } \\
\text { aunque no. se sub- } \\
\text { estima }\end{array}$ & $\begin{array}{l}\quad \text { (4) } \\
\text { Respeta las opi- } \\
\text { niones ajenas y } \\
\text { considera con equi } \\
\text { dad las proprias }\end{array}$ & $\begin{array}{l}\quad(3) \\
\text { Suele escuchar las } \\
\text { opiniones de otros } \\
\text { aunque es firme en } \\
\text { las suyas }\end{array}$ & $\begin{array}{l}\quad(2) \\
\text { Casi siempre quiere } \\
\text { imponer su criterio. } \\
\text { Subestima a los } \\
\text { demás }\end{array}$ & $\begin{array}{l}\text { (1) } \\
\text { No acepta las } \\
\text { opiniones de } \\
\text { otros. Actua } \\
\text { independientem. }\end{array}$ \\
\hline $\begin{array}{l}\text { (5) } \\
\text { Muy buenas rela- } \\
\text { ciones. Equitativo } \\
\text { con todos. No tie- } \\
\text { ne preferidos }\end{array}$ & $\begin{array}{l}\text { (4) } \\
\text { Rara vez ofende a } \\
\text { alguien. No tiene } \\
\text { preferencias }\end{array}$ & $\begin{array}{l}\text { (3) } \\
\text { Actua generalmente } \\
\text { con tacto. Avita en } \\
\text { lo posible las desa- } \\
\text { vencias. }\end{array}$ & $\begin{array}{l}\quad(2) \\
\text { Es algo brusco y } \\
\text { poco contemplativo } \\
\text { con sus hermanos }\end{array}$ & $\begin{array}{l}\text { (1) } \\
\text { Rudo y brusco. } \\
\text { Casi siempre } \\
\text { ofende }\end{array}$ \\
\hline $\begin{array}{l}\quad(5) \\
\text { Muy pulcro y } \\
\text { meticuloso. }\end{array}$ & $\begin{array}{l}\text { (4) } \\
\text { Ordenado, cuida- } \\
\text { doso y pulcro }\end{array}$ & $\begin{array}{l}\text { (3) } \\
\text { Limpio y arreglado } \\
\text { casi siempre }\end{array}$ & $\begin{array}{c}\text { (2) } \\
\text { Bastante desgar- } \\
\text { bado y descuidado }\end{array}$ & $\begin{array}{l}(1) \\
\text { Siempre desali- } \\
\text { nado. Casi } \\
\text { sucio. }\end{array}$ \\
\hline
\end{tabular}


A. EVANCELISMO PUBLICO

B. EVANELISMO PERSONAL ENSENANZAS

C. VISITACION - CONFIRMACION PASTORAL

D. PREFERENCIA POR LA JUVENTUD

E. ADMINISTRACION ECLESIASTICA

F. MOBILIZACION LAICOS

\begin{tabular}{|c|c|c|c|c|}
\hline $\begin{array}{l}\text { (5) } \\
\text { Buen orador. Ex- } \\
\text { celente aptitud y } \\
\text { tiene marcada pre } \\
\text { ferencia }\end{array}$ & $\begin{array}{l}\quad \text { (4) } \\
\text { Realiza buenas } \\
\text { reuniones de evan- } \\
\text { gelización } \\
\text { püblica }\end{array}$ & $\begin{array}{l}\text { (3) } \\
\text { Puede dar confe- } \\
\text { rencias con rela- } \\
\text { tivo éxito. No es } \\
\text { orador brillante }\end{array}$ & $\begin{array}{l}\text { (2) } \\
\text { Mediocre como con } \\
\text { ferenciante. No } \\
\text { atrae al publico }\end{array}$ & $\begin{array}{l}\text { (1) } \\
\text { No logra atraer } \\
\text { publico, ni tie- } \\
\text { ne aptitud de } \\
\text { orador }\end{array}$ \\
\hline $\begin{array}{l}\text { (5) } \\
\text { Excelente maestro. } \\
\text { Muy buen exposi- } \\
\text { tor público }\end{array}$ & $\begin{array}{l}\text { (4) } \\
\text { Buen maestro. } \\
\text { dad la doctrina }\end{array}$ & \begin{tabular}{|l|}
\multicolumn{1}{|c|}{$(3)$} \\
Como maestro es \\
acceptable. Bastan \\
te claro en sus \\
exposiciones
\end{tabular} & $\begin{array}{l}\text { (2) } \\
\text { Poca capacidad } \\
\text { de enseñar. Ex- } \\
\text { posiciones ambi- } \\
\text { guas y confusas }\end{array}$ & $\begin{array}{l}\text { (1) } \\
\text { Como maestro } \\
\text { y expositor } \\
\text { casi nulo }\end{array}$ \\
\hline $\begin{array}{l}\quad(5) \\
\text { visitador incansa- } \\
\text { ble. Sus visitas } \\
\text { son inspiradoras }\end{array}$ & $\begin{array}{l}\quad(4) \\
\text { visitador aprove- } \\
\text { cha bien las entre } \\
\text { vistas personales }\end{array}$ & $\begin{array}{l}\text { (3) } \\
\text { Visita con cierta } \\
\text { regularidad. Sus } \\
\text { visitas suelen ser } \\
\text { positivas }\end{array}$ & $\begin{array}{l}\quad(2) \\
\text { Poco visitador. } \\
\text { Algo torpe en los } \\
\text { encuentros } \\
\text { personales }\end{array}$ & $\begin{array}{l}\quad(1) \\
\text { Visita muy poco. } \\
\text { Saldo negativo } \\
\text { más bien en sus } \\
\text { entrevistas }\end{array}$ \\
\hline $\begin{array}{l}\text { (5) } \\
\text { Trabaja muy bien } \\
\text { por ellos y tiene } \\
\text { mucho ascendiente }\end{array}$ & \begin{tabular}{|c|} 
\\
A los jovenes les \\
gusta su persona- \\
lidad. Conduce \\
bien a la juventud
\end{tabular} & \begin{tabular}{|l|} 
\\
Mantiene bastante \\
vinculación con los \\
jóvenes e influye \\
algo en ellos
\end{tabular} & $\begin{array}{l}\text { (2) } \\
\text { Poco ascendiente } \\
\text { y escasa aptitud } \\
\text { para estar con los } \\
\text { jovenes }\end{array}$ & $\begin{array}{l}\text { (1) } \\
\text { No sabe tratar } \\
\text { con elllos. Tiene } \\
\text { frecuentes con- } \\
\text { flictos con ellos }\end{array}$ \\
\hline $\begin{array}{l}\text { (5) } \\
\text { Excelente capacidad } \\
\text { administrativa y. } \\
\text { promueve equili- } \\
\text { brada todas las } \\
\text { actividades }\end{array}$ & $\begin{array}{l}\text { (4) } \\
\text { Administración } \\
\text { buena y con cla- } \\
\text { ridad y buen } \\
\text { criterio }\end{array}$ & $\begin{array}{l}\quad(3) \\
\text { Administra con } \\
\text { mas aciertos que } \\
\text { errores }\end{array}$ & $\begin{array}{l}\text { (2) } \\
\text { Es unilateral. Po- } \\
\text { ca visión de } \\
\text { conjunto }\end{array}$ & $\begin{array}{l}\text { (1) } \\
\text { sin capacidad } \\
\text { administrativa }\end{array}$ \\
\hline $\begin{array}{l}\quad(5) \\
\text { Los moviliza, en- } \\
\text { fervoriza y orga- } \\
\text { niza muy bien y } \\
\text { con excelentes re- } \\
\text { sultados }\end{array}$ & $\begin{array}{l}\text { (4) } \\
\text { Utiliza bien las } \\
\text { fuerzas laicas. } \\
\text { Logra ponerlos } \\
\text { a la acción }\end{array}$ & $\begin{array}{l}\text { (3) } \\
\text { Consigue que algu } \\
\text { nos le acompanen } \\
y \text { trabajen }\end{array}$ & $\begin{array}{l}\text { (2) } \\
\text { No logra casi el } \\
\text { ápoyo de los laicos } \\
\text { y busca poco su } \\
\text { participación }\end{array}$ & $\begin{array}{l}\text { (1) } \\
\text { Piensa que él } \\
\text { puede y debe } \\
\text { hacer todo solo. }\end{array}$ \\
\hline
\end{tabular}


Vi. PREFERENCIAS Y APTITUDES

C. PROMOCIÓN RECURSOS PARA EXPANSIÓn

VII. SALUD

A. Resistencia fisica

B. ENFERMEDADES

C. REFORMA PRO SALUD
Cont. - Método W.H.W.

\begin{tabular}{|l|l|l|l|l|}
\hline \multicolumn{1}{|c|}{ (5) } & \multicolumn{1}{c|}{$(4)$} \\
$\begin{array}{l}\text { Extraordinario. } \\
\text { Obtiene donacio- } \\
\text { nes substanciosas } \\
\text { Custa proyectos de } \\
\text { expansion }\end{array}$ & $\begin{array}{l}\text { Se destaca en } \\
\text { obtener recur- } \\
\text { sos para diver- } \\
\text { sos proyectos }\end{array}$ & $\begin{array}{l}\text { Conseigue aportes } \\
\text { y contribuciones } \\
\text { aunque le resulta } \\
\text { dificil para su } \\
\text { personalidad }\end{array}$ & $\begin{array}{l}\text { (2) } \\
\text { Poco afecto a } \\
\text { solicitar dona- } \\
\text { ciones y promo- } \\
\text { ver las finanzas }\end{array}$ & $\begin{array}{l}\text { No le agrada } \\
\text { esa tarea. No se } \\
\text { interesa por ob- } \\
\text { tener recursos } \\
\text { para expansión }\end{array}$ \\
\hline
\end{tabular}

\begin{tabular}{|c|c|c|c|c|}
\hline $\begin{array}{c}(5) \\
\text { Infatigable }\end{array}$ & $\begin{array}{l}\text { (4) } \\
\text { Resistente }\end{array}$ & $\begin{array}{l}\text { (3) } \\
\text { Suporta la jornada } \\
\text { normal }\end{array}$ & $\begin{array}{l}\quad(2) \\
\text { Bastante } \\
\text { débil }\end{array}$ & $\begin{array}{l}\text { (1) } \\
\text { Muy debil }\end{array}$ \\
\hline $\begin{array}{l}\text { Nunca se enferma. } \\
\text { Sano }\end{array}$ & $\begin{array}{l}\text { (4) } \\
\text { Guarda cama } \\
\text { excepcionalmente }\end{array}$ & $\begin{array}{l}\text { (3) } \\
\text { Enfermedades comu } \\
\text { nes. Está una se- } \\
\text { mana en cama al } \\
\text { ano aproximadamen- } \\
\text { te }\end{array}$ & $\begin{array}{l}\quad(2) \\
\text { Enfermizo. Fre- } \\
\text { cuentemente } \\
\text { debe guardar } \\
\text { cama }\end{array}$ & $\begin{array}{l}\text { (1) } \\
\text { Salud muy } \\
\text { quebrantada }\end{array}$ \\
\hline $\begin{array}{l}\text { (5) } \\
\text { Enseña y practica } \\
\text { con equilibrio y } \\
\text { fidelidad los prin- } \\
\text { cipios y habitos de } \\
\text { reforma pro salud }\end{array}$ & $\begin{array}{l}\text { (4) } \\
\text { Con su vida y } \\
\text { enseñanza demues } \\
\text { tra su adhesión a } \\
\text { estos principios }\end{array}$ & $\begin{array}{l}\text { (3) } \\
\text { suele ser conse- } \\
\text { cuente con los } \\
\text { principios. Se } \\
\text { nota progreso. }\end{array}$ & $\begin{array}{l}\text { (2) } \\
\text { Bastante perni- } \\
\text { sivo en sus ha- } \\
\text { bitos alimenta- } \\
\text { rios. No hace } \\
\text { progresos. Defi- } \\
\text { ende posiciones } \\
\text { personales }\end{array}$ & $\begin{array}{l}\quad(1) \\
\text { Es muy liberal } \\
\text { en sus hábitos } \\
\text { alimentarios. No } \\
\text { acepta todos los } \\
\text { principios. }\end{array}$ \\
\hline
\end{tabular}


VIII. FAMILIA Y FINANZAS

A. HOGAR Y FAMILIA

B. ASCEN DiENTE DE LA ESPOSA EN LA IGLESIA $Y$ EL HOCAR

C. LOS HIJOS

D. ADMINISTRACION Y FINANZAS PERSONALES

E. INTERES POR LA OBTENCION DE GANANCIAS MATERIALES
Cont. - Método W.H.W.

\begin{tabular}{|c|c|c|c|c|}
\hline $\begin{array}{l}\qquad(5) \\
\text { Hogar ejemplar. } \\
\text { Mantiene gran as- } \\
\text { cendiente sobre } \\
\text { los suyos }\end{array}$ & $\begin{array}{l}\quad(4) \\
\text { Conduce bien su } \\
\text { hogar y las re- } \\
\text { laciones con los } \\
\text { suyos son bue- } \\
\text { nas }\end{array}$ & $\begin{array}{l}\text { (3) } \\
\text { Mantiene bastante } \\
\text { ordenada su familia } \\
\text { y casi siempre es } \\
\text { respectado }\end{array}$ & $\begin{array}{l}\text { (2) } \\
\text { Algo desordenado } \\
\text { Poco ascendiente } \\
\text { entre los suyos }\end{array}$ & $\begin{array}{l}\quad(1) \\
\text { Su autoridad es } \\
\text { casi nula sobre } \\
\text { su familia }\end{array}$ \\
\hline $\begin{array}{l}\text { Una madre de Is- } \\
\text { rael. Ejerce influ- } \\
\text { encia muy positiva }\end{array}$ & $\begin{array}{l}\text { (4) } \\
\text { Buena influencia } \\
\text { sobre el hogar y } \\
\text { la iglesia }\end{array}$ & $\begin{array}{l}\text { (3) } \\
\text { Se dedica bien a su } \\
\text { hogar pero poco par- } \\
\text { ticipa en la iglésia }\end{array}$ & $\begin{array}{l}\text { (2) } \\
\text { su influencia es } \\
\text { más bien negati- } \\
\text { va. Se inmiscuye } \\
\text { demasiado en los } \\
\text { asuntos eclesi- } \\
\text { ásticos }\end{array}$ & $\begin{array}{l}\text { (1) } \\
\text { su conducta in- } \\
\text { habilita y resiente } \\
\text { el ministerio de } \\
\text { su esposo }\end{array}$ \\
\hline $\begin{array}{l}\text { Son dechados. } \\
\text { Colaboran y apoyan } \\
\text { la tarea de su } \\
\text { padre }\end{array}$ & $\begin{array}{l}\text { (4) } \\
\text { Buenos hijos y } \\
\text { son buen ejempld } \\
\text { para otros } \\
\text { jóvenes }\end{array}$ & $\begin{array}{l}\text { (3) } \\
\text { Suelen conducirse } \\
\text { bien. A veces traen } \\
\text { problemas }\end{array}$ & \begin{tabular}{|l|}
\multicolumn{1}{|c|}{$(2)$} \\
Bastante indife- \\
rentes a las cosas \\
religiosas. No \\
se identifican con \\
tarea del padre
\end{tabular} & $\begin{array}{l}\text { (1) } \\
\text { Desobedientes, } \\
\text { irreligiosos. Un } \\
\text { baldón para su } \\
\text { padre }\end{array}$ \\
\hline $\begin{array}{l}\text { (5) } \\
\text { siempre se manti- } \\
\text { ene en su presu- } \\
\text { puesto. jamás se } \\
\text { endeuda }\end{array}$ & \begin{tabular}{l}
\multicolumn{1}{c}{$(4)$} \\
Su sueldo le \\
alcanza. No \\
compromete su \\
presupuesto
\end{tabular} & $\begin{array}{l}\text { (3) } \\
\text { Generalmente se ati- } \\
\text { ene al presupuesto. } \\
\text { A veces entra en } \\
\text { sendos compromisos }\end{array}$ & $\begin{array}{l}\text { (2) } \\
\text { Casi nunca le } \\
\text { alcanza su suel- } \\
\text { do. Suele com- } \\
\text { prometerse con } \\
\text { facilidad }\end{array}$ & $\begin{array}{l}\text { (1) } \\
\text { Vive de anticipos } \\
\text { Sempre endeuda- } \\
\text { do }\end{array}$ \\
\hline $\begin{array}{l}\text { (5) } \\
\text { No piensa en ganan } \\
\text { cias terrenales, } \\
\text { aunque es previsor }\end{array}$ & $\begin{array}{l}\quad \text { (4) } \\
\text { No tiene ambi- } \\
\text { ciones de ga- } \\
\text { nancias materi- } \\
\text { ales. Hace } \\
\text { prevision }\end{array}$ & $\begin{array}{l}\text { (3) } \\
\text { Se preocupa algo } \\
\text { aunque casi no se } \\
\text { manifiesta. Se con- } \\
\text { tenta con la remune- } \\
\text { ración que recibe }\end{array}$ & $\begin{array}{l}(2) \\
\text { Con frecuencia } \\
\text { habla y piensa } \\
\text { en ello. Bastan- } \\
\text { te descontento } \\
\text { con la remunera- } \\
\text { ción que recibe }\end{array}$ & \begin{tabular}{|l|} 
Es su obsesión. \\
Nunca le alcanza \\
para satisfacer su \\
afán de posesión \\
$y$ previsión
\end{tabular} \\
\hline
\end{tabular}


Method: W.H.W.

\begin{tabular}{|ll|}
\hline I. & Spiritual \\
& Qualities \\
\hline
\end{tabular}

A. DEDICATION (G.W.P. 111)

B. CONSISTENCY AND INTEGRITY

(G.W. pp. 141-44)

C. HUMILITY (G.W. P. 142)

D. FERVOR/ENTHUSIASM (G.W. P. 143)

E. PERSONAL DEVOTION (G.W. P. 145)
SELF-EVALUATION SCALE (AND OBSERVATION EVALUATION)

OF THE ADVENTIST MINISTER

\begin{tabular}{|c|c|c|c|c|}
\hline$(5)$ & $(4)$ & $(3)$ & (2) & $7(1)$ \\
\hline $\begin{array}{c}\text { Total \& } \\
\text { enthusiastic }\end{array}$ & Great & Average & $\begin{array}{c}\text { Needs } \\
\text { improvement }\end{array}$ & Poor \\
\hline $\begin{array}{l}\text { Strictly } \\
\text { faithful; does } \\
\text { not fear pres- } \\
\text { sure of the } \\
\text { majority }\end{array}$ & $\begin{array}{l}\text { Faithful and } \\
\text { firm in main- } \\
\text { tenance of } \\
\text { principles }\end{array}$ & $\begin{array}{l}\text { Faithful and } \\
\text { loyal }\end{array}$ & $\begin{array}{l}\text { Somewhat lib- } \\
\text { eral with no } \\
\text { clear and dis- } \\
\text { tinct position }\end{array}$ & $\begin{array}{l}\text { Very liberal } \\
\text { and permis- } \\
\text { sive; is not } \\
\text { faithful }\end{array}$ \\
\hline $\begin{array}{l}\text { Very humble \& } \\
\text { patient; rec- } \\
\text { ognizes his } \\
\text { limitations }\end{array}$ & Humble \& calm & $\begin{array}{l}\text { Quite humble; } \\
\text { strives for } \\
\text { improvement }\end{array}$ & $\begin{array}{l}\text { Little humil- } \\
\text { ity; superior } \\
\text { air; justifies } \\
\text { self }\end{array}$ & $\begin{array}{l}\text { Proud \& impa- } \\
\text { tient; domin- } \\
\text { ant ego; ex- } \\
\text { cuses ail his } \\
\text { actions }\end{array}$ \\
\hline $\begin{array}{l}\text { Always fervent } \\
\text { and enthusi- } \\
\text { astic }\end{array}$ & $\begin{array}{l}\text { Very fervent } \\
\text { and enthusi- } \\
\text { astic }\end{array}$ & $\begin{array}{l}\text { Usually fer- } \\
\text { vent \& en- } \\
\text { thusiastic }\end{array}$ & $\begin{array}{l}\text { Intermittent- } \\
\text { ly fervent \& } \\
\text { enthusiastic, } \\
\text { somewhat } \\
\text { apathetic }\end{array}$ & $\begin{array}{l}\text { Very apathetic } \\
\text { and indiffer- } \\
\text { ent }\end{array}$ \\
\hline $\begin{array}{l}\text { A Christian of } \\
\text { much prayer } \\
\text { \& devotion } \\
\text { which is re- } \\
\text { flected in } \\
\text { his life }\end{array}$ & $\begin{array}{l}\text { Is very } \\
\text { devout }\end{array}$ & $\begin{array}{l}\text { Average in } \\
\text { personal } \\
\text { devotion }\end{array}$ & $\begin{array}{l}\text { Little prayer } \\
\text { and devotion- } \\
\text { a) life }\end{array}$ & $\begin{array}{l}\text { No devotional } \\
l \text { ife at all }\end{array}$ \\
\hline
\end{tabular}


F. DISCERNMENT

(Ezek 44:23;

Ed., p. 227)

\begin{tabular}{|l|}
\hline II. \\
$\begin{array}{l}\text { Intellectual } \\
\text { Qualities }\end{array}$ \\
\hline
\end{tabular}

A. INTELLIGENT

(G.W. P. 111)

B. COMPREHENSION

c. BIBLICAL KNOWLEDGE

D. GENERAL KNOWLEDGE

E. COMMON SENSE

\begin{tabular}{|c|c|c|c|c|}
\hline (5) & (4) & (3) & (2) & $(1)$ \\
\hline $\begin{array}{l}\text { Quick, sharp, } \\
\text { clear in dis- } \\
\text { cernment } \\
\text { whether con- } \\
\text { venient or in- } \\
\text { convenient }\end{array}$ & $\begin{array}{l}\text { Clear discern- } \\
\text { ment in what } \\
\text { is convenient } \\
\text { that is not } \\
\text { specifically } \\
\text { legislated }\end{array}$ & $\begin{array}{l}\text { Applies well } \\
\text { general Bib- } \\
\text { lical princi- } \\
\text { ples to per- } \\
\text { sonal and } \\
\text { specific mat- } \\
\text { ters }\end{array}$ & $\begin{array}{l}\text { Little dis- } \\
\text { cernment. } \\
\text { Seldom applies } \\
\text { correctly gen- } \\
\text { eral princi- } \\
\text { ples in speci- } \\
\text { fic cases }\end{array}$ & $\begin{array}{l}\text { Has confused } \\
\text { criteria about } \\
\text { right and } \\
\text { wrong }\end{array}$ \\
\hline Outstanding & Superior & Norma 7 & $\begin{array}{l}\text { Mentally slow } \\
\text { and sluggish }\end{array}$ & $\begin{array}{l}\text { Probably has } \\
\text { some deficiency }\end{array}$ \\
\hline $\begin{array}{l}\text { Grasps things } \\
\text { extremely } \\
\text { well }\end{array}$ & $\begin{array}{l}\text { Understands } \\
\text { quickly with- } \\
\text { out explana- } \\
\text { tions }\end{array}$ & $\begin{array}{l}\text { Grasps wel1 } \\
\text { once he } \\
\text { understands }\end{array}$ & $\begin{array}{l}\text { Grasps only } \\
\text { the most } \\
\text { obvious }\end{array}$ & $\begin{array}{l}\text { Slow to grasp } \\
\text { important } \\
\text { things }\end{array}$ \\
\hline Theologian & $\begin{array}{l}\text { Wide Knowl- } \\
\text { edge of the } \\
\text { Bible }\end{array}$ & Normal & $\begin{array}{l}\text { Scant knowl- } \\
\text { edge of the } \\
\text { Bible }\end{array}$ & $\begin{array}{l}\text { Biblical illit- } \\
\text { erate of Bible }\end{array}$ \\
\hline Profound & Extensive & Average & Limited & Uninformed \\
\hline $\begin{array}{l}\text { Demonstrates } \\
\text { excellent com } \\
\text { mon sense in } \\
\text { confronting } \\
\text { difficult or } \\
\text { new situations }\end{array}$ & $\begin{array}{l}\text { Faces new } \\
\text { situations \& } \\
\text { solves prob- } \\
\text { lems well, } \\
\text { using good } \\
\text { common sense }\end{array}$ & $\begin{array}{l}\text { Usually ex- } \\
\text { hibits good } \\
\text { common sense }\end{array}$ & $\begin{array}{l}\text { Uses } 1 \text { ittle } \\
\text { common sense; } \\
\text { limited con- } \\
\text { cept of com- } \\
\text { mon sense }\end{array}$ & $\begin{array}{l}\text { Very disorien- } \\
\text { ted in this; } \\
\text { lack of common } \\
\text { sense frequent- } \\
\text { ly creates } \\
\text { problems }\end{array}$ \\
\hline
\end{tabular}


F. PREACHING

G. SPEECH

H. WRITING

III. Emotions

A. EMOTIONAL REACTIONS

B. ADAPTABILITY TO CHANGE AND MOVING

\begin{tabular}{|c|c|c|c|c|}
\hline (5) & (4) & (3) & (2) & (1) \\
\hline $\begin{array}{l}\text { Outstanding; } \\
\text { always pre- } \\
\text { sents clear, } \\
\text { defined, \& } \\
\text { uplifting } \\
\text { messages }\end{array}$ & $\begin{array}{l}\text { Presents clear } \\
\text { \& uplifting } \\
\text { messages for } \\
\text { the church }\end{array}$ & $\begin{array}{l}\text { Good and clear } \\
\text { preaching }\end{array}$ & $\begin{array}{l}\text { Sermons con- } \\
\text { fusing with } \\
\text { content of } \\
\text { little value }\end{array}$ & $\begin{array}{l}\text { Poor preach- } \\
\text { ing; sermons } \\
\text { have limited } \\
\text { meaning }\end{array}$ \\
\hline $\begin{array}{l}\text { Outstanding } \\
\text { \& accurate }\end{array}$ & $\begin{array}{l}\text { Very good and } \\
\text { correct }\end{array}$ & $\begin{array}{l}\text { Clear \& } \\
\text { correct }\end{array}$ & $\begin{array}{l}\text { Frequent } \\
\text { grammatical } \\
\text { errors, } \\
\text { mumbles }\end{array}$ & $\begin{array}{l}\text { Deficient; } \\
\text { inarticulate }\end{array}$ \\
\hline $\begin{array}{l}\text { Excellent } \\
\text { writer }\end{array}$ & $\begin{array}{l}\text { Above } \\
\text { average }\end{array}$ & $\begin{array}{l}\text { Good and } \\
\text { correct }\end{array}$ & $\begin{array}{l}\text { Some gram- } \\
\text { matical and } \\
\text { sentence } \\
\text { structure } \\
\text { errors }\end{array}$ & $\begin{array}{l}\text { Frequent lapse } \\
\text { in grammar, un- } \\
\text { able to develop } \\
\text { ideas logically }\end{array}$ \\
\hline $\begin{array}{l}\text { We11 control- } \\
\text { led \& even- } \\
\text { tempered }\end{array}$ & $\begin{array}{l}\text { Emotionally } \\
\text { mature }\end{array}$ & $\begin{array}{l}\text { Generally } \\
\text { controlled }\end{array}$ & $\begin{array}{l}\text { Quick to re- } \\
\text { act; } 1 \text { ittle } \\
\text { control }\end{array}$ & $\begin{array}{l}\text { Easily irrita- } \\
\text { ted; emotion- } \\
\text { ally volatile }\end{array}$ \\
\hline $\begin{array}{l}\text { Adapts easily } \\
\text { to all new } \\
\text { situations }\end{array}$ & $\begin{array}{l}\text { Adapts with- } \\
\text { out major } \\
\text { difficulty; } \\
\text { accepts } \\
\text { changes with } \\
\text { a positive } \\
\text { attitude }\end{array}$ & $\begin{array}{l}\text { Adapts, but } \\
\text { with some } \\
\text { effort }\end{array}$ & $\begin{array}{l}\text { Adapts } \\
\text { partial1y }\end{array}$ & $\begin{array}{l}\text { Does not adapt } \\
\text { well; lives in } \\
\text { permanent } \\
\text { frustration }\end{array}$ \\
\hline
\end{tabular}


C. ATTITUDES WHEN FACING PROBLEMS

D. REACTION TO PRAISE

E. REACTION TO CRITICISM AND SUGGESTIONS

F. WILLINGNESS TO ACCEPT PLANS [CONFERENCE PROGRAMS]

\begin{tabular}{|c|c|c|c|c|}
\hline$(5)$ & (4) & (3) & (2) & (1) \\
\hline $\begin{array}{l}\text { Confronts pro- } \\
\text { blems deci- } \\
\text { sively \& } \\
\text { strives to } \\
\text { solve them; is } \\
\text { very optimis- } \\
\text { tic }\end{array}$ & $\begin{array}{l}\text { Strives a } \\
\text { great deal } \\
\text { before giving } \\
\text { up; is opti- } \\
\text { mistic }\end{array}$ & $\begin{array}{l}\text { Does not seek } \\
\text { to avoid dif- } \\
\text { ficulties; } \\
\text { makes reason- } \\
\text { able efforts } \\
\text { to solve them }\end{array}$ & $\begin{array}{l}\text { Tries to avoid } \\
\text { problems; } \\
\text { makes } 1 \text { ittle } \\
\text { effort to } \\
\text { solve them; } \\
\text { gives up } \\
\text { quickly; is } \\
\text { pessimistic }\end{array}$ & $\begin{array}{l}\text { Avoids problems } \\
\text { ahead of time; } \\
\text { very pessi- } \\
\text { mistic }\end{array}$ \\
\hline $\begin{array}{l}\text { Very cautious; } \\
\text { never allows } \\
\text { himself to } \\
\text { get puffed up }\end{array}$ & Controlled & $\begin{array}{l}\text { Almost always } \\
\text { reacts satis- } \\
\text { factorily }\end{array}$ & $\begin{array}{l}\text { Somewhat in- } \\
\text { different } \\
\text { with a } \\
\text { tendency to } \\
\text { feel elated }\end{array}$ & $\begin{array}{l}\text { Either apath- } \\
\text { etic or } \\
\text { euphoric }\end{array}$ \\
\hline $\begin{array}{l}\text { Always accepts } \\
\text { graciously \& } \\
\text { weighs care- } \\
\text { fully }\end{array}$ & Controlled & $\begin{array}{l}\text { Generally } \\
\text { willing to } \\
\text { accept con- } \\
\text { structive } \\
\text { criticism or } \\
\text { suggestions } \\
\text { but sometimes } \\
\text { reacts nega- } \\
\text { tively }\end{array}$ & $\begin{array}{l}\text { Seldom accepts } \\
\text { suggestions or } \\
\text { criticism; } \\
\text { tends to be } \\
\text { confused }\end{array}$ & $\begin{array}{l}\text { Never accepts } \\
\text { even construc- } \\
\text { tive criticism } \\
\text { or observa- } \\
\text { tions }\end{array}$ \\
\hline $\begin{array}{l}\text { Enthusiasti- } \\
\text { cally accepts } \\
\text { them and adds } \\
\text { his own im- } \\
\text { provements }\end{array}$ & $\begin{array}{l}\text { Accepts them } \\
\text { wel } 1 \text { with a } \\
\text { spirit of } \\
\text { optimism }\end{array}$ & $\begin{array}{l}\text { Usually } \\
\text { accepts them } \\
\text { but sometimes } \\
\text { somewhat neg- } \\
\text { atively }\end{array}$ & $\begin{array}{l}\text { Rarely accepts } \\
\text { them; a Tways } \\
\text { makes objec- } \\
\text { tions \& finds } \\
\text { excuses for } \\
\text { rejecting them }\end{array}$ & $\begin{array}{l}\text { Always rejects } \\
\text { them, even } \\
\text { though he has } \\
\text { none of his } \\
\text { own to offer; } \\
\text { reacts nega- } \\
\text { tively \& lacks } \\
\text { faith }\end{array}$ \\
\hline
\end{tabular}


G. ATTITUDE WHEN MISTREATED OR OFFENDED

IV. Work

A. SENSE OF RESPONSIBILITY

B. ORGANIZATION AND ABILITY TO SCHEDULE

C. INDUSTRY \& DEDICATION (G.W. pp. 143-44)

\begin{tabular}{|c|c|c|c|c|}
\hline (5) & (4) & (3) & (2) & $(1)$ \\
\hline $\begin{array}{l}\text { Is open \& hum- } \\
\text { ble; does not } \\
\text { harbor bitter- } \\
\text { ness or hatred; } \\
\text { returns good } \\
\text { for evil }\end{array}$ & $\begin{array}{l}\text { Forgives \& } \\
\text { readily over- } \\
\text { looks anger- } \\
\text { producing } \\
\text { situations }\end{array}$ & $\begin{array}{l}\text { Usually for- } \\
\text { gets griev- } \\
\text { ances, al- } \\
\text { though not } \\
\text { without effort }\end{array}$ & $\begin{array}{l}\text { Holds a grudge } \\
\text { for some time; } \\
\text { at times is } \\
\text { revengeful }\end{array}$ & $\begin{array}{l}\text { Is bitter \& re- } \\
\text { vengeful; re- } \\
\text { pays evil with } \\
\text { evil; never } \\
\text { forgets the } \\
\text { offense }\end{array}$ \\
\hline $\begin{array}{l}\text { Highly respon- } \\
\text { sible \& con- } \\
\text { scientious }\end{array}$ & $\begin{array}{l}\text { Fulfills re- } \\
\text { sponsibili- } \\
\text { ties well }\end{array}$ & $\begin{array}{l}\text { Almost always } \\
\text { completes his } \\
\text { work }\end{array}$ & $\begin{array}{l}\text { Quite irre- } \\
\text { sponsible. } \\
\text { Frequently } \\
\text { leaves tasks } \\
\text { unfinished \& } \\
\text { often fails } \\
\text { to meet } \\
\text { appointments }\end{array}$ & $\begin{array}{l}\text { Irresponsible; } \\
\text { one cannot } \\
\text { have confi- } \\
\text { dence in him }\end{array}$ \\
\hline $\begin{array}{l}\text { Excellent } \\
\text { organizer \& } \\
\text { plans ahead }\end{array}$ & $\begin{array}{l}\text { Schedules wel] } \\
\text { \& efficiently; } \\
\text { tries to ac- } \\
\text { complish what } \\
\text { he sets out } \\
\text { to do }\end{array}$ & $\begin{array}{l}\text { Usually makes } \\
\text { a schedule \& } \\
\text { plans ahead }\end{array}$ & $\begin{array}{l}\text { Quite disor- } \\
\text { ganized \& does } \\
\text { not allow for } \\
\text { the unforeseen } \\
\text { usually faces } \\
\text { tasks with } \\
\text { confusion }\end{array}$ & $\begin{array}{l}\text { Very disorgan- } \\
\text { ized, con- } \\
\text { stantly chang- } \\
\text { ing plans--if } \\
\text { he has any }\end{array}$ \\
\hline $\begin{array}{l}\text { Completely } \\
\text { dedicated to } \\
\text { his work; very } \\
\text { good worker }\end{array}$ & $\begin{array}{l}\text { Very indus- } \\
\text { trious }\end{array}$ & $\begin{array}{l}\text { Quite indus- } \\
\text { trious; at } \\
\text { times is dis- } \\
\text { tracted on } \\
\text { personal mat- } \\
\text { ters }\end{array}$ & $\begin{array}{l}\text { Not very in- } \\
\text { dustrious; } \\
\text { somewhat lazy } \\
\text { \& lethargic; } \\
\text { spends a lot } \\
\text { of time on } \\
\text { personal items }\end{array}$ & $\begin{array}{l}\text { Lazy; lethar- } \\
\text { gic; spends a } \\
\text { lot of time in } \\
\text { idleness; ac- } \\
\text { compl ishes only } \\
\text { what he wants }\end{array}$ \\
\hline
\end{tabular}


D. PERSONAL INITIATIVE

E. MANUAL DEXTERITY

\section{F. EFFICIENCY \& PRODUCTIVITY}

G. ATTITUDE TOWARD WORK

\begin{tabular}{|c|c|c|c|c|}
\hline$(5)$ & (4) & (3) & (2) & $(1)$ \\
\hline $\begin{array}{l}\text { Has much per- } \\
\text { sonal initia- } \\
\text { tive; no one } \\
\text { ever has to } \\
\text { tell him what } \\
\text { to do }\end{array}$ & $\begin{array}{l}\text { Has initiative } \\
\text { \& proceeds } \\
\text { without [un- } \\
\text { necessary] } \\
\text { directions }\end{array}$ & $\begin{array}{l}\text { Shows some } \\
\text { initiative; at } \\
\text { times must be } \\
\text { shown what to } \\
\text { do }\end{array}$ & $\begin{array}{l}\text { It seldom oc- } \\
\text { curs to him } \\
\text { to initiate } \\
\text { sometime him- } \\
\text { self }\end{array}$ & $\begin{array}{l}\text { Must always be } \\
\text { shown what to } \\
\text { do \& how to do } \\
\text { it }\end{array}$ \\
\hline $\begin{array}{l}\text { Very skillful } \\
\text { in use of } \\
\text { hands for } \\
\text { manual \& } \\
\text { artistic tasks }\end{array}$ & $\begin{array}{l}\text { Does well } \\
\text { many tasks \& } \\
\text { artistic } \\
\text { things that } \\
\text { require man- } \\
\text { ual dexterity }\end{array}$ & $\begin{array}{l}\text { Demonstrates } \\
\text { some manual } \\
\text { dexterit- }\end{array}$ & $\begin{array}{l}\text { Quite clumsy: } \\
\text { not too help- } \\
\text { ful in this } \\
\text { area }\end{array}$ & $\begin{array}{l}\text { Clumsy \& use- } \\
\text { less for any- } \\
\text { thing requir- } \\
\text { ing manual } \\
\text { skill }\end{array}$ \\
\hline $\begin{array}{l}\text { Very produc- } \\
\text { tive \& effi- } \\
\text { cient }\end{array}$ & $\begin{array}{l}\text { Shows good } \\
\text { output; knows } \\
\text { how to get } \\
\text { results }\end{array}$ & $\begin{array}{l}\text { Normal effi- } \\
\text { ciency; Quite } \\
\text { productive }\end{array}$ & $\begin{array}{l}\text { Only spasmodic } \\
\text { efforts with } \\
\text { poor results }\end{array}$ & $\begin{array}{l}\text { Not efficienct } \\
\text { or productive }\end{array}$ \\
\hline $\begin{array}{l}\text { Very enthusi- } \\
\text { astic; always } \\
\text { willing; does } \\
\text { not work by } \\
\text { the clock }\end{array}$ & $\begin{array}{l}\text { Has good atti- } \\
\text { tude toward } \\
\text { his work; does } \\
\text { not count his } \\
\text { hours }\end{array}$ & $\begin{array}{l}\text { Does what is } \\
\text { strictly } \\
\text { necessary \& } \\
\text { works what is } \\
\text { required of } \\
\text { him }\end{array}$ & $\begin{array}{l}\text { Often needs to } \\
\text { be motivated } \\
\text { to work; quite } \\
\text { willing to } \\
\text { neglect some } \\
\text { things }\end{array}$ & $\begin{array}{l}\text { Works only } \\
\text { under direc- } \\
\text { tion \& when } \\
\text { obligated to } \\
\text { do so; always } \\
\text { needs a lot of } \\
\text { motivating }\end{array}$ \\
\hline
\end{tabular}


V. Human Relationships

A. LEADERSHIP

B. SELF-CENTEREDNESS (G.W., pp. 236-37; 507-08)

C. CHARISMA \& SOCIABILITY

(G.W. p. 140)

D. FELLOWSHIP \& TEAM SPIRIT

E, SELF-WORTH \& CONCEPT OF OTHERS

\begin{tabular}{|c|c|c|c|c|}
\hline (5) & (4) & (3) & (2) & (1) \\
\hline $\begin{array}{l}\text { Excellent } \\
\text { leader. who per } \\
\text { suades without } \\
\text { using force }\end{array}$ & $\begin{array}{l}\text { Strong person- } \\
\text { ality; has a } \\
\text { lot of influ- } \\
\text { ence over } \\
\text { people }\end{array}$ & $\begin{array}{l}\text { Good personal- } \\
\text { ity but not } \\
\text { always able to } \\
\text { lead others }\end{array}$ & $\begin{array}{l}\text { Only achieves } \\
\text { by forcing } \\
\text { people; is } \\
\text { easily influ- } \\
\text { enced }\end{array}$ & $\begin{array}{l}\text { Has no pres- } \\
\text { tige; is re- } \\
\text { jected as a } \\
\text { leader }\end{array}$ \\
\hline $\begin{array}{l}\text { Puts interests } \\
\text { of others } \\
\text { ahead of his } \\
\text { own }\end{array}$ & $\begin{array}{l}\text { Rarely puts } \\
\text { his own inter- } \\
\text { ests first }\end{array}$ & $\begin{array}{l}\text { Gives about } \\
\text { equal atten- } \\
\text { tion to his } \\
\text { own interests } \\
\& \text { those of } \\
\text { others }\end{array}$ & $\begin{array}{l}\text { Takes care of } \\
\text { his own inter- } \\
\text { ests; cares } \\
\text { little about } \\
\text { needs of } \\
\text { others }\end{array}$ & $\begin{array}{l}\text { Takes care of } \\
\text { himself; seeks } \\
\text { for self- } \\
\text { advantages; } \\
\text { pays no atten- } \\
\text { tion to others }\end{array}$ \\
\hline $\begin{array}{l}\text { Very friendly } \\
\text { very pleasant } \\
\text { \& has very } \\
\text { attractive } \\
\text { personality }\end{array}$ & $\begin{array}{l}\text { Is always } \\
\text { pleasant \& } \\
\text { friendly }\end{array}$ & $\begin{array}{l}\text { Is somewhat } \\
\text { changeable in } \\
\text { his relation- } \\
\text { ships with } \\
\text { others }\end{array}$ & $\begin{array}{l}\text { Tends to iso- } \\
\text { late himself; } \\
\text { not too com- } \\
\text { municative; } \\
\text { somewhat of } \\
\text { an introvert }\end{array}$ & $\begin{array}{l}\text { Terse; uncom- } \\
\text { municative; } \\
\text { anti-social }\end{array}$ \\
\hline $\begin{array}{l}\text { Fellowship } \\
\text { capacity is } \\
\text { excellent; } \\
\text { very good } \\
\text { teamworker }\end{array}$ & $\begin{array}{l}\text { Very good } \\
\text { friend; adapts } \\
\text { to team work }\end{array}$ & $\begin{array}{l}\text { A loyal friend } \\
\text { although he } \\
\text { prefers to } \\
\text { work alone. } \\
\text { usually works } \\
\text { satisfactorily } \\
\text { with others }\end{array}$ & $\begin{array}{l}\text { Not always } \\
\text { loyal to his } \\
\text { friends; seeks } \\
\text { personal ad- } \\
\text { vantage, rarely } \\
\text { works with } \\
\text { others }\end{array}$ & $\begin{array}{l}\text { Is not open; } \\
\text { his friends } \\
\text { are afraid of } \\
\text { him and reject } \\
\text { him. Unable } \\
\text { to work with } \\
\text { others }\end{array}$ \\
\hline $\begin{array}{l}\text { Very respect- } \\
\text { ful of others' } \\
\text { opinions with- } \\
\text { out underrat- } \\
\text { ing himself }\end{array}$ & $\begin{array}{l}\text { Respects the } \\
\text { opinions of } \\
\text { others on an } \\
\text { equal basis } \\
\text { with his own }\end{array}$ & $\begin{array}{l}\text { Hears others' } \\
\text { ideas but } \\
\text { holds firmly } \\
\text { to his own }\end{array}$ & $\begin{array}{l}\text { Almost always } \\
\text { tries to im- } \\
\text { pose his ideas } \\
\text { onto others; } \\
\text { undervalues } \\
\text { those of others }\end{array}$ & $\begin{array}{l}\text { Does not accept } \\
\text { others' opinions } \\
\text { acts inde- } \\
\text { pendently }\end{array}$ \\
\hline
\end{tabular}


F. TREATMENT OF FELLOWCHURCH MEMBERS

(G.W. p. 190)

G. PERSONAL APPEARANCE (G.W. pp. 145, 173)

\section{Preferences and} Aptitudes

A. PUBLIC EVANGELISM

B. PERSONAL EVANGELISM; TEACHING

C. YOUTH WORK

\begin{tabular}{|c|c|c|c|c|}
\hline (5) & (4) & (3) & (2) & (1) \\
\hline $\begin{array}{l}\text { Very good re- } \\
\text { lations; is } \\
\text { impartial with } \\
\text { all, not hav- } \\
\text { ing favorites }\end{array}$ & $\begin{array}{l}\text { Rarely of- } \\
\text { fends anyone; } \\
\text { has no fav- } \\
\text { orites }\end{array}$ & $\begin{array}{l}\text { Generally is } \\
\text { tactful; tries } \\
\text { to avoid dis- } \\
\text { agreements }\end{array}$ & $\begin{array}{l}\text { Is somewhat un } \\
\text { polished, car- } \\
\text { ing little for } \\
\text { the feelings } \\
\text { of others }\end{array}$ & $\begin{array}{l}\text { Unpolished \& } \\
\text { rude; has pen- } \\
\text { chant for of- } \\
\text { fending others }\end{array}$ \\
\hline $\begin{array}{l}\text { Meticulously } \\
\text { neat }\end{array}$ & Neat \& tidy & $\begin{array}{l}\text { Usualiy clean } \\
\text { \& neat }\end{array}$ & $\begin{array}{l}\text { Quite careless } \\
\text { about his } \\
\text { appearance }\end{array}$ & $\begin{array}{l}\text { Careless, dis- } \\
\text { orderly appear- } \\
\text { ance--almost } \\
\text { dirty }\end{array}$ \\
\hline & & & & \\
\hline $\begin{array}{l}\text { Outstanding } \\
\text { preacher; is } \\
\text { gifted in this } \\
\text { line \& likes } \\
\text { it }\end{array}$ & $\begin{array}{l}\text { Conducts good } \\
\text { public meet- } \\
\text { ings }\end{array}$ & $\begin{array}{l}\text { Can conduct } \\
\text { evangel istic } \\
\text { campaigns suc- } \\
\text { cessfully; is } \\
\text { not a bril- } \\
\text { liant speaker }\end{array}$ & $\begin{array}{l}\text { Mediocre as a } \\
\text { speaker; does } \\
\text { not attract } \\
\text { the public }\end{array}$ & $\begin{array}{l}\text { Does not at- } \\
\text { tract the pub- } \\
\text { lic; no abil- } \\
\text { ity in public } \\
\text { speaking }\end{array}$ \\
\hline $\begin{array}{l}\text { Excellent } \\
\text { teacher \& good } \\
\text { at expository } \\
\text { teaching of } \\
\text { the Bible }\end{array}$ & $\begin{array}{l}\text { Good teacher; } \\
\text { teaches doc- } \\
\text { trines clearly }\end{array}$ & $\begin{array}{l}\text { Acceptable as } \\
\text { a teacher; } \\
\text { quite clear } \\
\text { explanations }\end{array}$ & $\begin{array}{l}\text { Little ability } \\
\text { for teaching; } \\
\text { Explanations } \\
\text { ambivalent \& } \\
\text { confusing }\end{array}$ & $\begin{array}{l}\text { Almost useless } \\
\text { for any kind } \\
\text { of teaching }\end{array}$ \\
\hline $\begin{array}{l}\text { Works very } \\
\text { well with \& } \\
\text { influencential } \\
\text { with young } \\
\text { people }\end{array}$ & $\begin{array}{l}\text { The youth like } \\
\text { his personal- } \\
\text { ity; has good } \\
\text { rapport with } \\
\text { them }\end{array}$ & $\begin{array}{l}\text { Maintains good } \\
\text { relationship } \\
\text { with youth \& } \\
\text { influences } \\
\text { some of them }\end{array}$ & $\begin{array}{l}\text { Has little in- } \\
\text { fluence or ap- } \\
\text { titude for } \\
\text { working with } \\
\text { young people }\end{array}$ & $\begin{array}{l}\text { Cannot relate } \\
\text { with youth; has } \\
\text { frequent con- } \\
\text { flicts with } \\
\text { young people }\end{array}$ \\
\hline
\end{tabular}


D. VISITATION--PASTORAL CONFIRMATION

E. CHURCH ADMINISTRATION

F. MOBILIZATION OF THE LAITY

\begin{tabular}{|c|c|c|c|c|}
\hline$(5)$ & (4) & (3) & $(2)$ & (1) \\
\hline $\begin{array}{l}\text { Untiring in } \\
\text { visitation; } \\
\text { visits are } \\
\text { inspiring }\end{array}$ & $\begin{array}{l}\text { Employs per- } \\
\text { sonal visita- } \\
\text { tion profit- } \\
\text { ably }\end{array}$ & $\begin{array}{l}\text { Visits quite } \\
\text { regularly \& } \\
\text { the visits } \\
\text { are usually } \\
\text { positive }\end{array}$ & $\begin{array}{l}\text { Visits little; } \\
\text { somewhat un- } \\
\text { easy in meet- } \\
\text { ing people }\end{array}$ & $\begin{array}{l}\text { Visits very } \\
\text { little with } \\
\text { rather nega- } \\
\text { tive results } \\
\text { when he does }\end{array}$ \\
\hline $\begin{array}{l}\text { Outstanding } \\
\text { administrator; } \\
\text { has a balanced } \\
\text { program }\end{array}$ & $\begin{array}{l}\text { Good adminis- } \\
\text { trator with } \\
\text { a clear \& } \\
\text { good program }\end{array}$ & $\begin{array}{l}\text { Administers } \\
\text { with more } \\
\text { successes than } \\
\text { failures }\end{array}$ & $\begin{array}{l}\text { Is one-sided; } \\
\text { has little } \\
\text { ability to see } \\
\text { the whole } \\
\text { picture }\end{array}$ & $\begin{array}{l}\text { Has no admin- } \\
\text { istrative } \\
\text { ability }\end{array}$ \\
\hline $\begin{array}{l}\text { Motivates, or- } \\
\text { ganizes, \& } \\
\text { unites members } \\
\text { enthusiastic- } \\
\text { ally \& with } \\
\text { excellent re- } \\
\text { sults }\end{array}$ & $\begin{array}{l}\text { Makes good use } \\
\text { of the laity's } \\
\text { strengths; } \\
\text { tries to give } \\
\text { them active } \\
\text { work to do }\end{array}$ & $\begin{array}{l}\text { Gets some of } \\
\text { the laity to } \\
\text { accompany him } \\
\text { \& work with } \\
\text { him }\end{array}$ & $\begin{array}{l}\text { Has little } \\
\text { support from } \\
\text { the laity \& } \\
\text { looks to them } \\
\text { very little } \\
\text { for partici- } \\
\text { pation }\end{array}$ & $\begin{array}{l}\text { Thinks that } \\
\text { he is able \& } \\
\text { should do } \\
\text { everything } \\
\text { himself }\end{array}$ \\
\hline $\begin{array}{l}\text { Outstanding at } \\
\text { obtaining don- } \\
\text { ations; likes } \\
\text { expansional } \\
\text { projects }\end{array}$ & $\begin{array}{l}\text { Is successful } \\
\text { in obtaining } \\
\text { resources for } \\
\text { various expan- } \\
\text { sion projects }\end{array}$ & $\begin{array}{l}\text { Achieves sup- } \\
\text { port \& contri- } \\
\text { butions, al- } \\
\text { though it is } \\
\text { not easy for } \\
\text { him to do this }\end{array}$ & $\begin{array}{l}\text { Has little } \\
\text { interest in } \\
\text { asking for } \\
\text { donations or } \\
\text { for financial } \\
\text { promotion }\end{array}$ & $\begin{array}{l}\text { Does not like } \\
\text { this work; } \\
\text { does not in- } \\
\text { terest himself } \\
\text { with expansion } \\
\text { projects }\end{array}$ \\
\hline
\end{tabular}

G. PROMOTION FOR FUNDS FOR EXPANSION 
VII. Health

A. PHYSICAL RESISTANCE

B. ILLNESS

C. HEALTH REFORM

VIII. FAMILY AND PERSONAL FINANCES

A. HOME AND FAMILY

\begin{tabular}{|c|c|c|c|c|}
\hline (5) & (4) & (3) & (2) & (1) \\
\hline $\begin{array}{l}\text { Tireless, } \\
\text { never gets } \\
\text { worn out }\end{array}$ & $\begin{array}{l}\text { Has abundant } \\
\text { resistance }\end{array}$ & $\begin{array}{l}\text { Able to carry } \\
\text { on a normal } \\
\text { work schedule }\end{array}$ & $\begin{array}{l}\text { Tires quite } \\
\text { easily }\end{array}$ & Is very weak \\
\hline $\begin{array}{l}\text { Never gets } \\
\text { sick; is } \\
\text { healthy }\end{array}$ & $\begin{array}{l}\text { Rarely is } \\
\text { sick enough } \\
\text { to go to bed }\end{array}$ & $\begin{array}{l}\text { Succumbs only } \\
\text { to common il1- } \\
\text { nesses; usu- } \\
\text { ally laid up } \\
\text { about a week } \\
\text { each year }\end{array}$ & $\begin{array}{l}\text { Not too good } \\
\text { health; is } \\
\text { frequently ill }\end{array}$ & $\begin{array}{l}\text { Has very poor } \\
\text { health. Has } \\
\text { a chronic } \\
\text { health } \\
\text { problem }\end{array}$ \\
\hline $\begin{array}{l}\text { Teaches \& } \\
\text { faithfully } \\
\text { practices } \\
\text { healthful } \\
\text { habits \& } \\
\text { principles of } \\
\text { health reform }\end{array}$ & $\begin{array}{l}\text { His life \& } \\
\text { teaching dem- } \\
\text { onstrates his } \\
\text { adherence to } \\
\text { health prin- } \\
\text { ciples }\end{array}$ & $\begin{array}{l}\text { Usually is } \\
\text { consistent in } \\
\text { health prin- } \\
\text { ciples. Is } \\
\text { making pro- } \\
\text { gress }\end{array}$ & $\begin{array}{l}\text { Quite permis- } \\
\text { sive in eating } \\
\text { habits; is not } \\
\text { improving; is } \\
\text { defensive }\end{array}$ & $\begin{array}{l}\text { Is very liberal } \\
\text { in his eating } \\
\text { habits; does } \\
\text { not accept } \\
\text { health } \\
\text { principles }\end{array}$ \\
\hline $\begin{array}{l}\text { Exemplary } \\
\text { home; has } \\
\text { great influ- } \\
\text { ence on his } \\
\text { family }\end{array}$ & $\begin{array}{l}\text { Well-conducted } \\
\text { home with good } \\
\text { family rela- } \\
\text { tionships }\end{array}$ & $\begin{array}{l}\text { Maintains } \\
\text { quite a well- } \\
\text { ordered house- } \\
\text { hold and is } \\
\text { usually re- } \\
\text { spected }\end{array}$ & $\begin{array}{l}\text { Home life dis- } \\
\text { organized; } \\
\text { has little in- } \\
\text { fluence over } \\
\text { family members }\end{array}$ & $\begin{array}{l}\text { Has no author- } \\
\text { ity over his } \\
\text { family }\end{array}$ \\
\hline
\end{tabular}


B. WIFE'S INFLUENCE IN THE CHURCH AND HOME

C. THE CHILDREN

D. ADMINISTRATION OF PERSONAL FINANCES

E. INTEREST IN DISPLAY AND MATERIAL WEALTH

\begin{tabular}{|c|c|c|c|c|}
\hline (5) & (4) & (3) & (2) & (1) \\
\hline $\begin{array}{l}\text { Is a real } \\
\text { mother in Is- } \\
\text { rael; has a } \\
\text { positive in- } \\
\text { fluence }\end{array}$ & $\begin{array}{l}\text { Is a good in- } \\
\text { fluence in the } \\
\text { home \& in the } \\
\text { church }\end{array}$ & $\begin{array}{l}\text { Devoted to the } \\
\text { home; partici- } \\
\text { pates little } \\
\text { in the church }\end{array}$ & $\begin{array}{l}\text { Her influence } \\
\text { is rather } \\
\text { negative; in- } \\
\text { terferes a lot } \\
\text { in church } \\
\text { affairs }\end{array}$ & $\begin{array}{l}\text { Resents the } \\
\text { ministry work } \\
\text { of her husband }\end{array}$ \\
\hline $\begin{array}{l}\text { They are re- } \\
\text { spectful \& } \\
\text { support their } \\
\text { father's work }\end{array}$ & $\begin{array}{l}\text { They are good } \\
\text { children \& } \\
\text { good examples } \\
\text { for others }\end{array}$ & $\begin{array}{l}\text { Usually behave } \\
\text { well; some- } \\
\text { times create } \\
\text { problems }\end{array}$ & $\begin{array}{l}\text { Are quite in- } \\
\text { different to } \\
\text { religious mat- } \\
\text { ters; do not } \\
\text { identify with } \\
\text { father's work }\end{array}$ & $\begin{array}{l}\text { Are disobedient } \\
\text { \& disrespectful } \\
\text { a shame to } \\
\text { their father }\end{array}$ \\
\hline $\begin{array}{l}\text { Always follows } \\
\text { a budget; is } \\
\text { never in debt }\end{array}$ & $\begin{array}{l}\text { Salary is ade- } \\
\text { quate; fol- } \\
\text { lows budget } \\
\text { strictly }\end{array}$ & $\begin{array}{l}\text { Generally is } \\
\text { able to keep } \\
\text { within the } \\
\text { budget; some- } \\
\text { times gets } \\
\text { in debt. }\end{array}$ & $\begin{array}{l}\text { Salary almost } \\
\text { never is ade- } \\
\text { quate; gets } \\
\text { in debt easily }\end{array}$ & $\begin{array}{l}\text { Lives on ad- } \\
\text { vances; is al- } \\
\text { ways in debt. }\end{array}$ \\
\hline $\begin{array}{l}\text { Does not think } \\
\text { in terms of } \\
\text { earthly gain, } \\
\text { al though he } \\
\text { is a good } \\
\text { provider }\end{array}$ & $\begin{array}{l}\text { Has no earthly } \\
\text { ambitions for } \\
\text { material gain; } \\
\text { makes a good } \\
\text { living }\end{array}$ & $\begin{array}{l}\text { Is somewhat } \\
\text { concerned; but } \\
\text { this is hardly } \\
\text { noticeable; } \\
\text { is satisfied } \\
\text { with the re- } \\
\text { muneration he } \\
\text { receives }\end{array}$ & $\begin{array}{l}\text { Frequently } \\
\text { talks \& thinks } \\
\text { of money; is } \\
\text { unhappy with } \\
\text { his salary }\end{array}$ & $\begin{array}{l}\text { Obsessed with } \\
\text { money; never } \\
\text { satisfied with } \\
\text { his salary nor } \\
\text { his standard } \\
\text { of living }\end{array}$ \\
\hline
\end{tabular}


B I B L I O G RAPH Y 
Albrecht, Karl. Successful Management by Objectives: An Action Manual. Englewood Cliffs, NJ: Prentice-Ha11, Inc., 1978.

Anderson, Godfrey T. "The Minister and Culture." Ministry, October 1961, p. 14.

Anderson, Martin. Multiple Ministries: Staffing the Local Church. Minneapolis: Augsburg Pub. House, 1965.

Anderson, Roy Allan. The Shepherd-Evangelist. Washington, D.C.: Review and Herald Pub. Assn., 1950.

Andreasen, M. L. The Sanctuary Service. Washington, D.C.: Review and Herald Pub. Assn., 1947.

Azevedo, Roberto C. Projeto Brasil. Sao Paulo: South Brasil Union Press, 1973.

Barclay, Williams. The Letter to the Romans. Philadelphia: Westminster Press, 1957.

Bietz, Reinhold R. "The Minister's Calling, Work, and Responsibility.", Ministry, August 1954, p. 12.

Blackwood, Andrew W. The Growing Minister: His Opportunities and Obstacles. New York: Abingdon Press, 1960.

Blizzard, Samuel W. "The Minister's Dilemma." The Christian Century 73 (1956):508-09.

Bourdeau, T. D. "Editorial." Adventist Review and Sabbath Herald, December 2, 1862.

"Church, Nature of." SDA Encyclopedia. 1976 ed. 10:302.

Cleveland, Earl E. "The Decline of the Ministry." Ministry, December 1969, p. 5.

- "Who Put You IN?" Ministry, January 1969, pp. 46-47.

Coffey, Cecil. The Church God Built. Washingtin, D.C.: Review and Herald Pub. Assn., 1972. 
Costas, Orland E. The Church and Its Mission: A Shattering Critique from the Third World. Wheaton, IL: Tyndale House Pub., 1974.

Cruden, Alexander A. D. Cruden's Complete Concordance. Grand Rapids: Zondervan Pub. House, 1968.

Dederen, Raoul. "Theology of Ordination." Ministry, July 1972. (Supplement), p. 24K,L.

. "The Nature of the Church." Ministry, February 1978 (Supplement), p. 24C.

Douglas, William G. T. "Predicting Ministerial Effectiveness." Ph.D. dissertation, Harvard University, 1957.

Drucker, Peter F. Management: Tasks, Responsibilities, Practices. New York: Harper \& Row, 1973.

Dulles, Avery S. J. Models of the Church. Garden City, NY: Doubleday \& Company, 1974.

Edwards, Rex D. A New Frontier: Every Believer a Minister. Mountain View, CA: Pacific Press Pub. Assn., 1979.

"Ellen G. White Comments" [1 Pet 2:5]. SDA Bible Commentary. Edited by F. D. Nichol. Washington, D.C.: Review and Herald Pub. Assn., 1954, 1977.

Engstrom, Ted. W., and Dayton, Edward R. The Art of Management for Christian Leaders. Waco, TX: Word Books Pub., 1976.

Evans, Irvin Henry. The Preacher and His Preaching. Washington, D.C.: Review and Herald Pub. Assn., 1938.

Forsyth, P. T. Positive Preaching and the Modern Mind. New York: Hodder \& Stoughton, 1907.

French, W. R. "The Call to the Ministry." Ministry, August 1929, p. 31.

Froom, Leroy Edwin. "The Ministerial Call and Calling." Ministry, November 1940, p. 22.

Gulley, Norman R. Adult Sabbath School Lesson. January-March 1983, p. 96 .

Hassenpflug, B. E. "Your Call to the Work of God." Ministry, August 1953, p. 8.

Haynes, Carlyle B. "Called of God: Are You Sure?". Ministry, January 1955, p. 8. 
Holmes, Urban Tisner. The Priest in Community: Exploring the Roots of Ministry. New York: The Seabury Press, 1978.

Japas, Salin. "A Strategy for Seventh-day Adventist Public Evangelism within a Roman Catholic Society Context in Hispanic America." D.Min. dissertation,. Andrews University, 1978.

Jones, E. Stanley. Growing Spiritually. New York: Abingdon Press, 1953.

Kadel, Thomas E., ed. Growth in Ministry. Philadelphia: Fortress Press, 1980.

Keck, Leander E. The Bible in the Pulpit. Nashville: Abingdon Press, $197 \overline{8 .}$

Kilinski, Kenneth $K_{.}$, and Wofford, Jerry C. Organization and Leadership in the Local Church. Grand Rapids: Zondervan Pub. House, 1973.

Klimes, Rudolf E. Realistic Planning. Berrien Springs, MI: Andrews University Print Shop, 1978.

Küng, Hans. The Church. New York: Sheed and Ward, 1967.

La11, Bernard M., and Lal1, Geeta R. Dynamic Leadership. Mountain View, CA: Pacific Press Pub. Assn., 1979.

Lindgren, Alvin J. Foundations for Purposeful Church Administration. Nashville: Abingdon Press, 1978.

Lindgren, Alvin J., and Shawchuck, Norman. Management for Your Church. Nashville: Abingdon Press, 1977.

Mali, Paul. Managing by Objectives. New York: John Wiley \& Sons, 1972 .

Manson, T.W. The Church's Ministry. Philadelphia: Westminster Press, 1948.

McDonough, Reginald M. "Growing Ministers, Growing Churches." Church Administration Magazine, February 1983, p. 2.

'McRae, William. The Dynamics of Spiritual Gifts. Grand Rapids: Zondervan, 1967.

Mead, Daniel L., and Allen, Darrel J. Ministry by Objectives. Wheaton, IL: : Evangelical Teacher Training Assn., 1978.

Melo, Luiz Silva. "A Rationale and Suggested Program for Ministers" Support Groups for Seventh-day Adventist Pastors in Brazil." D.Min. dissertation, Andrews University, 1981. 
Minear, Paul. Images of the Church in the New Testament.

Philadelphia: Westminster Press, 1960.

"Nature." Webster's New International Dictionary. 1961 ed. Edited by William Allan Neilson. Springfield, MA:

G. S. C. Merrian Company Pub., 1959.

Newbigin, James Edward Lesslie. The Good Shepherd. Grand Rapids: William B. Eerdmans Pub. Co., 1977.

Oosterwal, Gottfried. "The Mission of the Church 1972." Ministry, July 1972 (supplement), p. 24H. 1972.

Mission: Possible. Nashville: Southern Pub. Assn.,

- Servants for Christ: The Adventist Church Facing the '80s. Berrien Springs, MI: Andrews University Press, 1980.

Purkiser, W. T. The New Testament Images of the Ministry. Kansas City: Beacon Hill Press, 1969.

Raia, Anthony P. Managing by Objectives. Glenview, IL: Scott, Foresman and Co., 1974.

Reeves, C. Angus. "The One Supreme Qualification." Ministry, October 1938, p. 14.

Reiswig, J. J. "The Holy Calling of the Ministry." Ministry, February 1952, p. 5.

Reynolds, Keld J. "The Ministry in an Era of Expertise." Ministry, December 1967, p. 16.

Richards, Lawrence $0 .$, and Hoeldke, Clyde. A Theology of Church Leadership. Grand Rapids: Zondervan Pub. House, 1980.

Richards, Lawrence 0. , and Martin, Gib. A Theology of Personal Ministry. Grand Rapids: Zondervan Pub. House, 1981.

Schnackenburg, Rudolf. The Church in the New Testament. London: Burns \& Oates, 1974 .

Schuller, David S. The Christian Encounters the New Urban Society. St. Louis, M0: Concordia Pub. House, 1966.

Seventh-day Adventist Church Manual. General Conference of Seventh-day Adventists, 1976.

Spicer, William A. The Spirit of Prophecy in the Adventist Movement. Washington, D.C.: Review and Herald Pub. Assn., 1937. 
Torrance, Thomas Forsyth. Royal Priesthood. London: 01iver and Boyd Ltd., Reprinted 1963.

Vine, William Edwyn. An Expository Dictionary of New Testament Words. 5 vols. Westwood: Fleming H. Revell Co., 1940, 1952 .

Wagner, C. Peter. Your Church Can Grow. Glendale, CA: Regal Books Division, G/L Publications, 1976.

Wand, John William Charles. The Church: Its Nature, Structure and Function. London: Ebenezer Baylis and Son, 1950.

Watson, David. I Believe in the Church. Grand Rapids: William B. Eerdmans Publishing Co:, 1978.

Welch, Claude. The Reality of the Church. New York: Charles Scribner's Sons, 1958.

White, Ellen G. Acts of the Apostles. Mountain View, CA: Pacific Press Pub. Assn., 1917.

- Child Guidance. Nashville: Southern Pub. Assn., 1954.

- Christian Service. Washington, D.C.: Home Missionary Department of the General Conference of Seventh-day Adventists, 1947.

- Christ's Object Lessons. Washington, D.C.: Review and Herald Pub. Assn., 1941.

- Counsels on Health. Mountain View, CA: Pacific Press Pub. Assn., 1951.

- Counsels on Stewardship. Washington, D.C.: Review and Herald Pub. Assn., 1940.

- Counsels to Parents and Teachers. Mountain View, CA: Pacific Press Pub. Assn., 1943.

- Desire of Ages. Mountain View, CA: Pacific Press

Pub. Assn., 1955.

- Education. Mountain View, CA: Pacific Press Pub. Assn., 1952.

- Evangelism. Washington, D.C.: Review and Herald Pub. Assn., 1946.

. "The Foreigners in America." Review and Herald, October 29, 1914. 
- Fundamentals of Christian Education. Nashville:

Southern Pub. Assn., 1923.

- Gospel Workers. Washington, D.C.: Review and Herald

Pub. Assn., 1915.

- Great Controversy. Mountain View, CA: Pacific

Press Pub. Assn., 1911.

- Medical Ministry. Mountain View, CA: Pacific Press

Pub. Assn., 1963.

- Ministry of Healing. Mountain View, CA: Pacific

Press Pub. Assn., 1942.

- Ms. 55, 1897. Ellen G. White Research Center, Berrien Springs, Michigan.

- Patriarchs and Prophets. Mountain View, CA: Pacific Press Pub. Assn., 1958.

- Prophets and Kings. Mountain View, CA: Pacific

Press Pub. Assn., 1917.

- Selected Messages. 2 vol. Washington, D.C.: Review and Herald Pub. Assn., 1958.

- Sons and Daughters of God. Washington, D.C.: Review and Herald Pub. Assn., 1955.

- Spiritual Gifts. 4 vols. Washington, D.C.: Review and Herald Pub. Assn., 1945.

- Testimonies for the Church. 9 vols. Mountain View,

CA: Pacific Press Pub. Assn., 1948.

- Testimonies to Ministers. Mountain View, CA:

Pacific Press Pub. Assn., 1923.

Wilcox, Francis McLellan. The Testimony of Jesus. Washington, D.C.: Review and Herald Pub. Assn., 1944.

Willis, Graig S. The Art of Preaching: A Syllabus for RE 161-Homiletics. Adventist Seminary of West Africa. Mimeographed, n.d.

\section{Interviews}

FG, Pastor. Andrews University, Berrien Springs, Mich. Interview. 1 February 1983. 
HI, Pastor. Andrews University, Berrien Springs, Mich. Interview. 1 February 1983.

IF, Pastor. Andrews University, Berrien Springs, Mich. Interview. 1 February 1983. 
VITA

Itamar Sabino de Paiva

Born: April 10, 1934 Avanhandava, Sao Paulo, Brazil

Wife: Ruth Duarte de Paiva

Children: Ruimar, Elimar, Emerson, Hernan

Education:

High School: River Plate School, graduated 1955.

College: River Plate College--Theology, B.A. graduated 1958

River Plate Sanatorium--Red Cross

International Nurse, graduated 1958

Graduate: $\quad$ Andrews University, M.A., graduated 1980

Experience:

1959-1968 Minister, Mission Launch and Airplane, Youth and Education Department, Sabbath School and Lay Activities Department North Brazil Union (2 missions)

1969-1973 President

East Peruvian Mission

1974-1975 Minister

Panama Conference--Brazil

1976-1978 Secretary and Stewardship Department

So. R. G. Sul Conference--Brazi门 